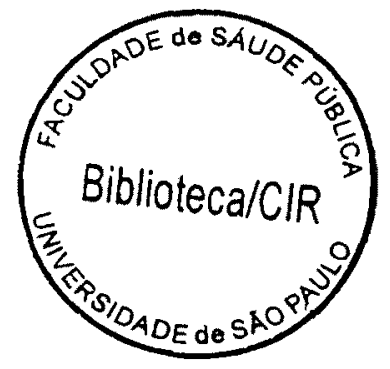

\title{
A ABORDAGEM ECOSSISTÊMICA APLICADA AO LICENCIAMENTO DE VEGETAÇÃO NATURAL: O CASO DO MUNICÍPIO DE DESCALVADO, SP
}

IRACI DA SILVA LEME MONTEIRO

Tese apresentada ao Departamento de Saúde Ambiental da Faculdade de Saúde Publica da Universidade de São Paulo para obtenção do Grau de Doutor.

Área de concentração:

Saúde Ambiental

Orientadora: Dra. Denise Navas Pereira 
Autorizo, exclusivamente para fins acadêmicos e cientificos, a reprodução total ou parcial desta dissertação, por processos fotocopiadores. Assinatura:

Data

$$
40483 / 2000(\text { doc) }
$$


UM HOMEM NÃO PODE FAZER O CERTO NUMA ÁREA DA VIDA, ENQUANTO ESTÁ OCUPADO EM FAZER O ERRADO EM OUTRA.

A VIDA É UM TODO INDIVISÍVEL.

Mahatma Gandhi 


\section{AGRADECIMENTOS}

A Dra. Denise Navas Pereira, minha orientadora, meu exemplo profissional e amiga de todas a horas.

Aos Profs. Marcelo Pereira de Souza, da EESC/USP e José Salatiel Rodrigues Pires, do LAPAUFSCAR, pelo apoio integral e certamente sem o auxilio dos quais não teria sido possivel a realização deste trabalho.

Aos Professores da Faculdade de Saúde Pública, Dr. Aristides de Almeida Rocha, pelas mãos de quem iniciei minha carreira acadêmica, e à Dra. Helena Ribeiro, pelas criteriosas e importantes considerações neste trabalho.

Ao Eng. Agrônomo Victor Eduardo Lima Ranieri pela inestimável contribuição no empréstimo das imagens digitalizadas.

À CETESB que proporcionou toda a minha formação profissional desde a época de estagiária, nos idos 1976, até esta etapa.

Ao DEPRN onde, nos últimos anos, muito aprendi sobre a natureza e em especial pelo apoio dos meus colegas e amigos Márcia Talarico, Florisvaldo Moreira, Danilo Angelucci do Amorim, Victor E. G. Ferreira, Solange Shunck, Ana Olivia de M. Reis e Osvaldo Bruno.

Ao município de Descalvado, com todo meu carinho, e à Prefeitura Municipal, pela atenção e assistência, nas pessoas do Secretário de Agricultura e Meio Ambiente, Sr. Sérgio de Marco e ao Eng. Agrônomo José Paggiaro e demais funcionários.

Aos Promotores Públicos de Descalvado e São Carlos, Dr. Mário de Barros Gentil, Dr. Edward Ferreira Filho e Dr. Denilson de Souza Freitas por tudo que me ensinam diariamente.

Aos meus amigos queridos: Clarice e Tavinho, Rosa, Vânia e Dú, Alvaro e Maj-lys, Nara e Dú, Mariângela e André, Carla e Márcio, Helga e Márcio, Adriana e Mega, Margarete e Zézinho, Bia e Cabeto, Ana e Eduardinho, Alina, Sandra e ao Rafael (Fó), dos quais eu me descuidei nos últimos tempos; entretanto, sempre estiveram ao meu lado apesar disso. 
À minha mãe, um anjo da guarda neste mundo e ao meu pai, um anjo da guarda noutro mundo

Ao querido Pedro, companheiro há vinte e cinco anos, incansável em cuidados e afeto.

Aos meus grandes amores e razões da minha vida, com meus pedidos de desculpas pela ausência em alguns momentos importantes de suas vidas, Marilia, Maria Beatriz e Lígia.

E a Deus, que me ajudou superar algumas duras etapas vividas nesse período e pelas diárias bênçãos recebidas. 


\section{RESUMO}

Monteiro, I.S.L. A abordagem ecossistêmica aplicada ao licenciamento de vegetação natural: o caso do município de Descalvado, SP. São Paulo; novembro, 2000. [Tese de Doutorado - Faculdade de Saúde Pública da USP].

O licenciamento para uso e exploração dos recursos de vegetação natural é efetuado, em regra, de forma pontual. Com o objetivo de acrescentar uma visão ecossistêmica aos procedimentos de licenciamento, foi realizado um estudo de caso, utilizando uma metodologia com instrumentos de geoprocessamento (imagens de satélite, Sistema Geográfico de Informação SIG e "Global Positionig System" - GPS). Também foi analisada a legislação afeta à matéria no sentido de identificar lacunas legais que podem comprometer a proteção de áreas de vegetação natural relevantes, pela supressão de "habitats". Como metodologia para aplicação dos referenciais teóricos abordados, foi efetuada a caracterização ambiental do município de Descalvado (SP), através do levantamento de dados primários e secundários obtidos, entre outros, pelo levantamento das áreas com vegetação natural utilizando a imagem de satélite TM Landsat 1997 e vistorias em campo com GPS. Foram analisados aspectos ambientais qualitativos da área de estudo, e quantitativos, com relação ao tamanho e número dos fragmentos, com uma abordagem voltada para a conservação da biodiversidade. Paralelamente, foi analisada a legislação relacionada à proteção das florestas. Dentre os resultados obtidos, salienta-se o quadro de fragmentação apresentado pela análise da imagem de satélite, pela qual constatou-se que as áreas de vegetação natural vêm sofrendo fortes pressões decorrentes da atividade antrópica. Foram contabilizados, na área de estudo, 684 fragmentos de vegetação natural, sendo que a maioria dos mesmos $(58,19 \%)$ com tamanho reduzido (entre 1 e $5 \mathrm{ha}$ ). A cobertura de vegetação natural no município é de aproximadamente $14.397,61$ ha, correspondente a apenas $19 \%$ da área total. Conclui-se que a utilização da metodologia proposta apresenta facilidades e 
acrescenta a visão ecossistêmica necessária à atividade de licenciamento dos recursos naturais, e que a cobertura de vegetação natural da área de estudo encontra-se extremamente fragmentada e sob forte pressão negativa pela atividade antrópica. Com relação à legislação, verifica-se que muitas formações importantes de vegetação natural (cerrado e campos de várzea) não encontram proteção legal suficiente.

Descritores: conservação da biodiversidade, Sistema Geográfico de Informação - SGI; "Global Positionig System" - GPS, legislação, licenciamento de vegetação natural. 


\section{SUMMARY}

Monteiro, I.S.L. A abordagem ecossistêmica aplicada ao licenciamento de vegetação natural: o caso do município de Descalvado, SP [The ecosystemic approach applied to the licensing of natural vegetation: the case study in the municipality of Descalvado, State of São Paulo]. São Paulo (BR); November, 2000. [Tese de Doutorado - Faculdade de Saúde Pública da Universidade de São Paulo].

Licensing for use and exploration of natural resources is usually carried out on a punctual basis. In order to add a systemic viewpoint to the licensing procedures, a case study was carried out using as methodology geoprocessing instruments (satellites images, Geographic Information System - GIS and Global Positionig System - GPS). Related legislation was also checked, for eventual legal gaps that could affect the protection of natural vegetation areas. A case study was developed in the municipality of Descalvado, State of São Paulo, using survey, by images of the Satellite Thematic Mapper (TM) Landsat 1997, of natural vegetation areas, as well as field inspections with GPS. The studied areas were analyzed for qualitative aspects, and quantitative aspects were related to size and number of fragments, the approach being of biodiversity conservation. Legislation related to forest protection was also analyzed. Analysis of those fragments pictures obtained from images of the satellite showed a fragmentation situation that evidenced strong stress on natural vegetation areas due to antropic activities. The study area included vegetation fragments, most of them $(58,19 \%)$ of small sizes ( 1 to $5 \mathrm{ha}$ ). Natural vegetation cover in the municipality is $14.397,61 \mathrm{ha}$, what is only $19 \%$ of the total area. It can be said that the use of the proposed methodology is simple and adds the systemic approach, which is needed for the licensing of natural resources. Regarding legislation, it could be observed that several important forms of natural vegetation are not sufficiently protected. 
Descriptors: Descritores: biodiversity conservation; Geographic Information System - GIS; Global Positionig System - GPS; legislation; licensing of natural vegetation. 


\section{ÍNDICE}

1. INTRODUÇÃO

2. OBJETIVOS

3. REFERENCIAIS TEÓRICOS

3.1. A evolução do conceito de desenvolvimento sustentável ........................7

3.2. Biodiversidade - Aspectos conceituais ........................................... 10

3.3. A Política Ambiental com vista à conservação da

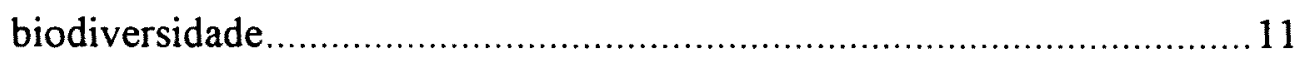

3.4. Definições e instrumentos de gestão dos recursos naturais...................... 15

3.4.1. Legislação relacionada à proteção de florestas $\mathrm{e}$ demais formas de vegetação natural ...................................... 17

3.4.2. Licenciamento e fiscalização dos recursos naturais ......................30

3.4.3. Instrumentos econômicos para implementação da Politica Ambiental .............................................................. 31

3.4.4. Sistemas de Unidades de Conservação - Instrumento para conservação da biodiversidade in situ ................................. 32

3.4.5. Caracterização ambiental como base para implementação do licenciamento dos recursos naturais 37

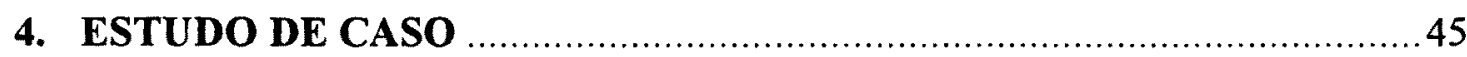

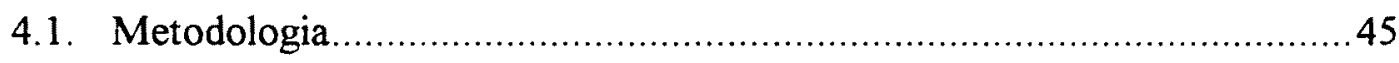

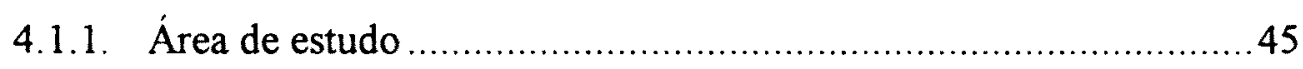

4.1.2. Levantamento e sistematização das informações para caracterização ambiental ................................................. 45

4.1.3. Áreas averbadas como Reservas Legais .................................52

4.1.4. Legislação pertinente e procedimentos no Ministério Público 


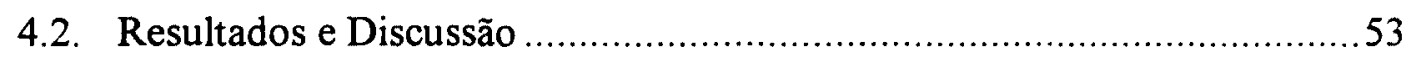

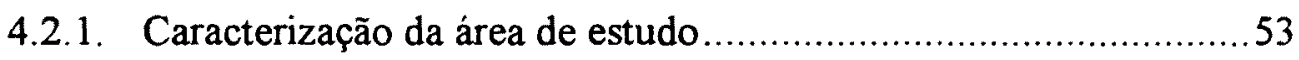

4.2.2. Identificação dos fragmentos de vegetação natural ......................69

4.2.3. As áreas de Reserva Legal do município de

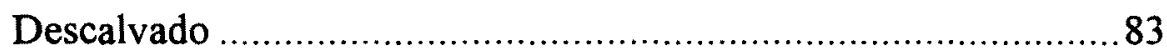

4.2.4. Procedimentos na Promotoria Pública de Descalvado..................85

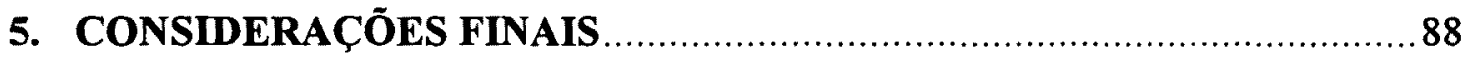

6. CONCLUSÕES

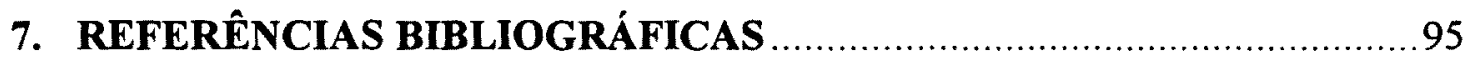

ANEXO - Relação das Reservas Legais do município de Descalvado 
LISTA DE TABELAS

Tabela 1 - Representatividade dos biomas brasileiros no Sistema Nacional de Unidades de Conservação Federal

Tabela 2 - Sintese das áreas de cerrado protegidas no Estado de São Paulo

Tabela 3 - Distribuição do número de propriedades rurais por área no município de Descalvado (SP)

Tabela 4 - Distribuição dos fragmentos de vegetação natural registrados na imagem Landsat, 1997.

Tabela 5 - Localização (em UTM) e avaliação de campo de alguns fragmentos de vegetação natural, com GPS e imagem de satélite, no município de Descalvado (SP)

Tabela 6 - Distribuição por tamanho (ha) das Reservas Legais averbadas registradas no município de Descalvado até dezembro de 1999 


\section{LISTA DE FIGURAS}

Figura 1 - Localização do municipio de Descalvado, SP.

Figura 2 - Transparência com a grade ("grid") de coordenadas UTM do município de Descalvado (SP), utilizada em campo.

Figura 3 - Imagem georreferenciada TM Landsat 1997 do município de Descalvado (SP), utilizada para identificação dos fragmentos de vegetação natural

Figura 4 - Matriz de vulnerabilidade ecológica simplificada para avaliação qualitativa dos fragmentos de vegetação natural

Figura 5 - Modelo digital de elevação do município de Descalvado (SP)

Figura 6 - Formação geológica do município de Descalvado (SP), com valores percentuais por tipo de formação.

Figura 7 - Pedologia do município de Descalvado (SP), com a classificação das grandes classes e valores percentuais por classe de solo

Figura 8 - Mapa síntese de susceptibilidade à erosão do município de Descalvado (SP), com a classificação e valores percentuais por categoria em relação à área

Figura 9 - Vista da boçoroca de São Clemente, no município de Descalvado

Figura 10 - Hidrografia do município de Descalvado (SP)

Figura 11 - Vista de parte da área de preservação permanente marginal ao Rio do Pântano, no município de Descalvado (SP)

Figura 12 - Pegadas de fauna silvestre fotografadas na região

Figura 13 - Pegadas de fauna silvestre fotografadas na região .68

Figura 14 - Pegadas de fauna silvestre fotografadas na região 69

Figura 15 - Fragmentos de vegetação natural no municipio de Descalvado, SP, obtidos a partir da digitalização da imagem TM Landsat 1997 
Figura 16 - Numero de fragmentos florestais do municipio de Descalvado. acrupados por tamato de trea, em bectares.

Figura 17 - Porcentagem de trea de vegetaplo natural ocupada, por classes de tragmentos; ma legende consta tumben o nimero de fragmentos por classe

Figura 18 - Retireda de cascalho dentro de uma Reserva Leal de Floresta Estacional Semi-Decidua no municipio de Descalvado

Figura 19 - Desmuamento asorizado para aividade de minerapla, dencro de extenso fragmento de cerredo no municipio de Descalvado (SP)

Figura 20 - Desmatarento nlo autorizado realizado para implantaclo de Distrito Industrial dentro de extenso fragmento de cerrado no municipio de Descalvado (SP).

Figura 21 - Ocupeplo da margem do rio Mogj-Guapu por cutura de cane-de-apicar no municipio de Descalvado. SP

Figura 22 - Remanescentes de vegetaplo natural do municipio de Desealvado (F37 e F38), indicados como treas de iexeresse pere implanteclo de Unidades de Conservaplo -o Projato de Macroconenmento des becias dos rios Mogi-Guncu, Pardo e Madio Grande

Figura 23 - Corte raso de vegetaplo nativa após a averbeglo de Reserva Legal, no municipio de Descalvado (SP) 86 


\section{LISTA DE SIGLAS E ABREVIATURAS}

APA - Área de Proteção Ambiental

CETESB - Companhia de Tecnologia de Saneamento Ambiental

CMMAD - Comissão Mundial para o Meio Ambiente e

Desenvolvimento

CONAMA - Conselho Nacional do Meio Ambiente

CPRN - Coordenadoria de Proteção dos Recursos Naturais

DEPRN - Departamento Estadual de Proteção dos Recursos Naturais

ECO-92 - Conferência das Nações Unidas sobre Meio Ambiente e

Desenvolvimento

EEC - Escola de Engenharia de São Carlos .

FEHIDRO - Fundo Estadual de Recursos Hídricos

FLES - Floresta Estacional Semi-Decidual

GPS - "Global Positioning System"

ha - Hectares (10.000 metros quadrados)

L/B - Razão Interior Borda

IAC - Instituto Agrônomico de Campinas

IBAMA - Instituto Brasileiro do Meio Ambiente e dos Recursos

Renováveis

IBGE - Instituto Brasileiro de Geografia e Estatística

ICMS - Inposto sobre circulação de mercadorias e serviços

InB- Indice de Borda

ITR - Imposto Territorial Rural

LAPA - Laboratório de Análise e Planejamento Ambiental

ONU - Organização das Nações Unidas

RPPN - Reserva Particular do Patrimônio Natural

SMA - Secretaria de Estado do Meio Ambiente do Governo do Estado

de São Paulo

TAC - Termo de Ajustamento de Conduta

TM - "Thematic Mapper"

UC - Unidade de Conservação 
UTM - Projeção Universal Transversa de Mercator

ZEE - Zoneamento Ecológico-Econômico 


\section{INTRODUÇÃO}

Historicamente, verifica-se que o desenvolvimento de uma nação tem sido acompanhado pelo esgotamento de seus recursos naturais, tanto pelo aumento de demanda da matéria prima como pela falta de planejamento na ocupação dos espaços fisicos.

Entretanto, na realidade, constata-se que, apesar do uso intensivo e predatório dos recursos naturais, uma considerável parcela da população mundial encontra-se em limites considerados abaixo da pobreza.

A constatação das conseqüências nefastas dessa forma predatória de crescimento gerou, nas últimas décadas, questionamentos que culminaram em consenso com relação ao conceito de "desenvolvimento sustentóvel".

Vários fatores diretamente relacionados ao desenvolvimento estão estreitamente ligados ao exaurimento dos recursos florestais de uma nação, tais como o extrativismo desordenado e excessivo e a expansão da fronteira agropecuária e urbana. Tais intervenções conduzem ao rompimento do equilíbrio de ecossistemas, que resulta em graves conseqüências ao bem-estar das populações, pelos inúmeros desequilibrios de balanço hídrico, pelo aumento da erosão do solo, pela degradação da flora e da fauna silvestres, pela deterioração da produção de alimentos, pelos desequilíbrios meteorológicos geradores de secas e enchentes, pelas mudanças causadas na paisagem e mesmo pela poluição ambiental que, em algumas condições extremas, pode atingir o nivel de irreversibilidade. Outro fator de preponderância fundamental no exaurimento dos recursos florestais é o aumento populacional de uma região (PÉLLICO NETO e BRENA, 1993).

Algumas das maiores pressões que ocasionavam os desmatamentos nos Países do Primeiro Mundo estão em declínio, em especial porque a madeira vem sendo pouco utilizada, por exemplo, na construção naval ou como combustivel na metalurgia. Essas foram as principais causas da destruição das florestas na Europa (ROOSE et al., 1997).

Todavia, nos paises tropicais, novas causas de desmatamento vieram somarse às antigas e o desflorestamento assumiu proporções inquietantes. Segundo estudos 
do Programa das Nações Unidas para o Meio Ambiente - PNUMA e da Organização das Nações Unidas para Alimentação e Agricultura - FAO, as florestas tropicais desaparecem à razão de 11,3 milhões de hectares por ano. Nesse ritmo, nove paises em desenvolvimento terão esgotado suas florestas em 25 anos, e outros 13, em cinqüenta anos (ROOSE et al., 1997).

O crescimento das terras cultiváveis constitui a principal causa do desflorestamento tropical. Sob a pressão de um povoamento humano cada vez mais denso, a agricultura invade as áreas florestais. A criação da malha rodoviária permitiu que a exploração chegasse a regiões florestais até então impenetráveis.

A utilização de madeira como combustível é a outra significativa contribuição ao desflorestamento tropical. A quantidade de árvores abatidas para produzir lenha para aquecimento e carvão vegetal é aproximadamente oito vezes maior do que a quantidade derrubada para produção industrial de madeira. Quanto à exploração industrial, que deve responder a uma demanda crescente de madeira de lei e de pasta de papel, constitui uma séria ameaça de destruição das florestas, caso não haja um planejamento racional. Às causas anteriores somam-se os efeitos sobre a cobertura florestal por causa das pastagens, pela caça e pela prática das queimadas (ROOSE et al., 1997).

No Brasil, a alta concentração industrial no Sul/Sudeste ocasiona forte pressão sobre a cobertura florestal, e a sua exploração ainda ocorre acima do limite de equilibrio na ocupação de seu espaço vital. Além desse fato, a melhoria do padrão de vida da população gera um aumento na demanda por produtos oriundos da madeira, tais como papel, construção de moradias e mobiliário, entre outros (PÉLLICO NETO e BRENA, 1993).

Historicamente, o processo de ocupação do território nacional até a década de 1940 estava exclusivamente calcado na expansão horizontal das fronteiras agrícolas, principalmente das culturas de exportação, como a da cana-de-açúcar e o café, esta última a que mais contribuiu para a destruição dos ecossistemas naturais no Estado de São Paulo. Entre os anos 1950 e 1980, houve grande avanço na produção de industrializáveis, incrementando-se o processo de metropolização das cidades. Além disso, entre 1968 e 1980, periodo de rápido crescimento, a própria política governamental estimulou o avanco das fronteiras agropecuárias. com vouca atencão 
para os aspectos ambientais. Mais que isso, até estimulou, com incentivos fiscais, uma ocupação que implicou na conversão de áreas florestais em áreas de agropecuária, em grande parte dos casos no Cerrado e na Amazônia (BRITO et al., 1999; WWF e PRO-CER, 2000).

Embora os subsídios governamentais dessa natureza tenham cessado, processos de conversão de áreas de vegetação natural para outros usos continuam ocorrendo. $\mathrm{O} 1^{\circ}$ Relatório Nacional para a Convenção sobre Diversidade Biológica, de 1998, aponta que os biomas brasileiros continuam a sofrer conseqüências de estruturas econômicas e sociais geradas ao longo de séculos, assim como de politicas econômicas anteriores à definição de estratégias mais adequadas em termos ambientais (WWF e PRO-CER, 2000).

No Estado de São Paulo, a eliminação da vegetação natural foi ocorrendo por etapas, à medida que a fronteira agricola ia avançando do Leste para Oeste. A primeira formação florestal a ser praticamente extinta foi a floresta estacional semi decidual (Domínio de Mata Atlântica), que ocupava as terras férteis da Depressão Periférica e do Planalto Ocidental. De início, a floresta cedeu lugar às lavouras de café, depois à agropecuária e, atualmente, esse solo vem sendo ocupado pelas culturas de cana-de-açúcar, laranja e soja. As pequenas manchas de cerrado que sobreviveram à ocupação, por terem seus solos considerados marginais para agricultura, agora cedem lugar às florestas de produção (Pinus e eucalipto), ou mesmo a culturas agrícolas, que, através de melhoramento genético, foram adaptadas aos solos ácidos e de baixa fertilidade (SÃO PAULO, 1992).

Em São Paulo se localizam os maiores e mais preservados remanescentes de Mata Atlântica, e a quase totalidade desses remanescentes concentra-se em Unidades de Conservação, nas áreas mais inacessiveis da Serra do Mar, enquanto as partes Norte e Oeste do Estado foram quase inteiramente desmatadas à corte raso. Em conseqüência disso, perdem-se anualmente duzentos milhões de toneladas de solo agrícola, que são carreados para os corpos d'água pela erosão, gerando ao mesmo tempo assoreamento, comprometendo qualitativa e quantitativamente os recursos hídricos, e acelerando o processo de desertificação em dois milhões de hectares de terras (SÃO PAULO, 1993). 
Os remanescentes de matas e formações associadas no Estado de São Paulo somam 1.900 .000 ha, equivalentes a 7,5\% do seu território. As áreas mais expressivas e melhor preservadas, totalizando cerca de 840.000 ha, situam-se justamente nas Unidades de Conservação, administradas pelo Governo, perfazendo pouco mais de $3 \%$ do território paulista. Nos últimos anos, levantamentos comprovam a critica situação da cobertura vegetal do Estado de São Paulo, onde $80 \%$ da vegetação original foi substituída, restando hoje apenas fragmentos isolados de alguns ecossistemas, evidenciando a redução substancial de todos os tipos de vegetação e a ameaça de extinção de várias espécies da flora e da fauna silvestres (BRITO et al., 1999).

Os próprios remanescentes situados nas unidades de conservação não têm sua preservação assegurada, uma vez que o Estado detém o efetivo controle dominial de apenas $19 \%$ da área total. Em outros 10\%, representados por áreas em processo de regularização fundiária, o controle é relativo. Nos $71 \%$ restantes, há 127.600 ha de terras públicas passiveis de perda de controle patrimonial pela falta de fiscalização (SÃo PAULO, 1993).

Tanto a floresta estacional semi-decidual (Mata Atlântica) como o cerrado são biomas definidos como "hotspots" de biodiversidade pela Conservation International - CI, uma das maiores entidades ambientalistas do mundo, ou seja, são áreas consideradas com alto grau de diversidade biológica em termos de endemismo e que sofrem alto grau de ameaça (CONSERVATION INTERNATIONAL, 2000).

Por esses motivos, as questões ambientais vêm ganhando espaço nas agendas dos mais diversos setores sociais brasileiros, que demonstram interesse crescente em unir essas questões às analises sócio-econômicas e institucionais.

Sobre este pano de fundo, foi desenvolvido o presente trabalho, que propõe fornecer subsidios para otimizar o desempenho na gestão dos fragmentos florestais naturais, possibilitando uma visão mais abrangente de situações vistas, na maior parte das vezes, de forma pontual, facilitando,assim, a incorporação do conceito de sustentabilidade e manutenção da diversidade biológica às tomadas de decisão neste campo.

Embora os diversos critérios técnicos utilizados para emissão de autorizações de corte raso, manejo e determinação das reservas legais dos fragmentos florestais 
tenham por base estudos acadêmicos e científicos, faz-se necessária a utilização de uma metodologia que os incorpore e seja de fácil aplicação, para subsidiar a tomada de decisão.

Este trabalho propõe a utilização de tecnologias avançadas, tais como Sensoriamento Remoto e Sistema Geográfico de Informações, como ferramenta à atividade de gestão dos recursos naturais voltadas para uma abordagem ecossistêmica. A utilização da metodologia proposta poderá ser de substancial utilidade na prática do licenciamento e na avaliação da fragmentação da cobertura de vegetação natural de áreas extensas.

Outro aspecto a ser enfocado neste trabalho é a análise do instrumental legal aplicado à proteção dos recursos naturais e identificação de lacunas que permitem autorização à corte raso de fragmentos florestais que tecnicamente deveriam ser mantidos.

Por causa do enfoque sistêmico assumido na abordagem da gestão florestal e do licenciamento de recursos naturais, entendeu-se ser necessário acrescentar ao trabalho a evolução de alguns conceitos (desenvolvimento sustentável, biodiversidade, gestão ambiental e outros), bem como um aspecto institucional que permeia vários tópicos que, aparentemente, fogem ao escopo da matéria "florestal", mas que são imprescindiveis para o entendimento da questão do licenciamento florestal voltado para uma abordagem ecossistêmica.

Foi desenvolvida, assim, uma análise das bases conceituais e instrumentos legais, que nortearam a aplicação em um estudo de caso, realizado no município de Descalvado, Estado de São Paulo. 


\section{OBJETIVOS}

\section{Objetivo Geral}

Discutir políticas, critérios e instrumentos de gestão ambiental para subsidiar - estabelecimento de licenciamento de vegetação natural com uma abordagem ecossistêmica, em consonância com o conceito de desenvolvimento sustentável.

\section{Objetivos Específicos}

Utilização de Sensoriamento Remoto e Sistema Geográfico de Informações para realização da caracterização ambiental e avaliação da fragmentação florestal em uma aplicação de estudo de caso: Municipio de Descalvado, SP.

Revisão da questão florestal sob o ponto de vista legal, para verificar extensão da proteção da diversidade biológica. 


\section{REFERENCIAIS TEÓRICOS}

\subsection{A evolução do conceito de Desenvolvimento Sustentável}

Grande parte da humanidade vive intensamente a sua responsabilidade pelo futuro do planeta e pela sobrevivência das gerações vindouras. Por este motivo, temse questionado, no presente, o antigo conceito do desenvolvimento a qualquer custo, e colocado como meta ideal o modelo de desenvolvimento com a manutenção do suporte de vida.

Segundo ODUM (1988), um fenômeno que se pode descrever como um movimento mundial de consciência ambiental despontou durante os anos de 1968 a 1970, quando o mundo voltou suas atenções à poluição, às áreas naturais, ao crescimento populacional e consumo de alimentos e energia, conforme a ampla cobertura de assuntos ambientais na imprensa popular.

Alguns dos principais trabalhos dessa época foram divulgados pelo denominado Clube de Roma, grupo de 30 individuos com diferentes formações cientistas, pedagogos, humanistas, industriais, entre outros - que se reuniram, em 1968, para debater a crise atual e futura da humanidade. O grupo patrocinou uma série de relatórios, que portavam o rótulo geral de "A crise da Humanidade". $O$ primeiro relatório da série, "Os limites do crescimento", conhecido como "Relatório Medows", publicado em 1970, predizia como seria o futuro se não houvesse modificação nos métodos econômicos e políticos vigentes, com base em modelos computacionais. As saidas dos modelos demonstraram que, em muitos casos ou em relação a muitos recursos vitais, ocorreriam ciclos de crescimento e colapso. Este relatório denunciou a obsessão da sociedade com o crescimento, no qual, em todos os âmbitos, a meta era a de se tornar cada vez maior, mais rico e mais poderoso, sem considerar o custo final do crescimento exponencial. Embora o propósito fosse simplesmente mostrar o que poderia acontecer se não fossem mudados os hábitos, $o$ relatório teve um grande impacto; logo ganhou repercussão mundial, e muitos o entenderam como se estivesse prevendo o fim da civilização, desencadeando criticas ao que foi considerado seu tom apocalíptico. A este seguiram-se outros, que tentaram não apenas dar maiores detalhes sobre as situações atuais e possiveis cenários futuros, como também sugerir ações que deveriam ser realizadas a fim de se evitar o 
fim do mundo. Estas questões passaram a atrair mais intensamente o interesse acadêmico de diversas áreas do conhecimento conduzindo ao surgimento de inúmeras teorias, predições e exercícios teóricos sobre as relações entre desenvolvimento e meio ambiente. $O$ entendimento comum dominante à época era de que o desenvolvimento econômico e a qualidade ambiental eram antagônicos e, por vezes, inconciliáveis (ODUM, 1988; ALMEIDA, 1998; SOUZA, 2000).

Em 1972, foi realizada em Estocolmo a Conferência das Nações Unidas sobre o Ambiente Humano, com a participação de 113 países, 250 organizações não governamentais e organismos da ONU. Os principais resultados formais do encontro foram a "Declaração sobre o Ambiente Humano" e o "Plano de Ação para o Meio Ambiente". A conferência de Estocolmo foi o ponto de partida para que a discussão ambiental se disseminasse, perpassando o âmbito acadêmico para alcançar o circuito governamental multilateral e a sociedade civil (SÃO PAULO, 1992; ODUM, 1988; ALMEIDA, 1998; SOUZA, 2000).

A partir de então, segundo SACHS (1986), passou-se a dar ênfase à necessidade de considerar a gestão racional do meio e dos recursos naturais como dimensão adicional do desenvolvimento e não propriamente como nova forma do mesmo. Começou, então, a ser empregada nos diversos estudos internacionais sobre meio ambiente a abordagem do Ecodesenvolvimento, ou seja, o conceito de Desenvolvimento Sustemtável. Ignacy Sachs, integrante dos principais grupos de trabalho dos mais importantes eventos mundiais sobre meio ambiente, emprega os dois termos como sinônimos (SACHS, 1994).

Uma resposta às preocupações sobre o crescente impacto das atividades humanas sobre os recursos naturais surgiu em 1983, quando a Organização das Nações Unidas - ONU criou a Comissão Mundial para o Meio Ambiente e Desenvolvimento - CMMAD, presidida pela então primeira ministra da Nonuega, Harlem Gro Brundtland, com o objetivo de discutir e propor meios de harmonizar os dois conceitos. Esta Comissão lançou, em 1987, o relatório "Nosso Futuro Comum", também denominado "Relatório Brundtland", que aborda as complexas causas dos problemas sociais, econômicos e ecológicos de uma sociedade globalizada, relacionando economia, tecnologia, sociedade e política, e atentando para uma postura ética entre as gerações e a necessidade de uma equidade internacional. $O$ 
mesmo relatório apresenta a definição mais aceita atualmente para desenvolvimento sustentável, ou seja, "aquele que é capaz de suprir as necessidades da geração atual, sem comprometer a capacidade de atender as necessidades das gerações futuras". $O$ "Relatório Brundtland" torna-se, então, referência para as estratégias futuras, que culminou na Conferência das Nações Unidas sobre Meio Ambiente e Desenvolvimento - ECO 92, realizada em junho de 1992, no Rio de Janeiro.

$\mathrm{Na}$ ECO-92, foram assumidos alguns princípios de políticas de meio ambiente, especialmente aquelas relacionadas a problemas ambientais com repercussão global, tais como as convenções sobre mudanças climáticas e sobre a conservação da biodiversidade. Foi também aprovado um programa internacional de ação que permitisse interromper e reverter os efeitos da degradação ambiental, denominado "Agenda 21", recomendado para governos, agências de desenvolvimento, organizações das Nações Unidas e grupos setorias independentes. Segundo SOUZA (2000), a "Agenda 21" aponta para a necessidade de uma ampla revisão das ações humanas, com vistas a conceber novas práticas capazes de propiciar um desenvolvimento mais equilibrado.

De acordo com SACHS (1994), existem cinco dimensões de sustentabilidade: social, econômica, ecológica, espacial (configuração rural-urbana mais equilibrada) e cultural (respeito às especificidades). $\mathrm{O}$ autor relaciona, como os principais avanços obtidos na área ambiental, a partir de 1970 , os progressos conceituais, a ampliação do conhecimento científico sobre problemas ambientais, $o$ avanço na institucionalização da preocupação com a gestão ambiental (quase todos os paises possuem ministérios ou agências para planejamento e implementação de políticas ambientais, bem como legislação especifica), inúmeras convenções, acordos e tratados internacionais, além da crescente conscientização da opinião pública.

Essa evolução também afetou profundamente $o$ escopo da ecologia acadêmica, que antes era vista como uma subdivisão da biologia, e que, a partir da década de 1970, passou a ser vista como disciplina integradora, essencialmente nova, que une os processos físicos e biológicos e serve como ponte entre as ciências naturais e ciências sociais (ODUM, 1988).

A incorporação do conceito de desenvolvimento sustentável na utilização de recursos naturais é hoje reconhecida como imprescindivel para a estabilidade do 
planeta e perpetuidade das espécies. Pode ser consolidada pela utilização eficiente de instrumentos de gestão na implementação da política ambiental, sendo o licenciamento ambiental um dos mais efetivos, se bem utilizado.

No sentido de implementar o conceito de desenvolvimento sustentável nas tomadas de decisão relacionadas ao licenciamento de atividades que interferem nos recursos de vegetação natural foi efetuada, no decorrer deste trabalho, uma discussão abrangente de diversos fatores intervenientes: cenário da política florestal, instrumentos de gestão relacionados (caracterização ambiental, legislação, entre outros), bem como de conceitos, técnicas e critérios relevantes para enfatizar a abordagem ecossistêmica no licenciamento ambiental (florestal). Essas discussões foram traduzidas em um estudo de caso.

\subsection{Biodiversidade - Aspectos Conceituais}

É dificil compreender como a transformação de áreas florestais em extensas áreas de cultura de soja ou cana localizadas em uma determinada região pode, a longo prazo, trazer prejuízos ao sustento de uma população de uma região distinta, ou como o desmatamento na região amazônica pode afetar o clima global. Entretanto, estes exemplos referem-se à biodiversidade (PIRES, 1999).

As funções ecológicas da diversidade biológica, ou biodiversidade, ainda não são compreendidas em toda sua extensão, embora se considere que ela seja responsável pelos processos naturais e produtos fornecidos pelos ecossistemas e espécies que sustentam outras formas de vida e modificam a biosfera, tornando-a apropriada e segura para a vida. Além de seu valor intrínseco, possui valor social, econômico, científico, genético, recreativo, paisagístico, estético, entre outros (DIAS, 2000).

A diversidade biológica refere-se a toda variedade de vida no planeta, incluindo: toda variedade genética dentro das populações e espécies; a variedade de espécies da flora, da fauna e de microrganismos; a variedade de funções ecológicas desempenhadas pelos organismos nos ecossistemas, bem como a variedade de comunidades, habitats e ecossistemas formados pelos organismos. Refere-se tanto ao número (riqueza) de diferentes categorias biológicas quanto à abundância relativa (equitabilidade) dessas categorias. Inclui, ainda, a variabilidade em âmbito local 
(alfa-diversidade) e variabilidade entre paisagens (gama-diversidade). Em suma, considera a totalidade dos recursos vivos (biológicos), dos recursos genéticos e seus componentes (DIAS, 2000).

Tanto a comunidade cientifica quanto governos e sociedade civil vêm alertando para a perda da diversidade biológica em todo mundo e, em especial, nas regiōes tropicais.

Os principais processos responsáveis pela erosão da biodiversidade são: a perda e fragmentação dos habitats, introdução de espécies e doenças exóticas, exploração excessiva de espécies de plantas e animais, utilização de híbridos e monoculturas nos programas de reflorestamento, contaminação do solo, água e atmosfera por poluentes, e mudanças climáticas.

Para assegurar a conservação da diversidade biológica, são necessários investimentos consideráveis; entretanto, deve-se considerar as inúmeras vantagens no plano ambiental, social e econômico deles advindo, ainda que o desenvolvimento social e econômico e a erradicação da pobreza sejam prioridades nos países em desenvolvimento.

O Brasil é considerado o país com a maior diversidade biológica do mundo. Segundo DIAS (2000), estima-se que aqui ocorram de 10 a $20 \%$ do número total de espécies do planeta. $O$ País apresenta a flora mais diversificada do mundo, com mais de 55.000 espécies descritas, que representam $22 \%$ do total mundial, com 390 espécies de palmeiras e 2.300 espécies de orquídeas. Com relação à fauna, foram registradas 394 espécies de mamíferos, 1.573 de aves, 498 de répteis, 502 de anfibios e mais de 3.000 espécies de peixes Estima-se que existam mais de dois milhões de espécies diferentes de fauna, flora e microrganismos; entretanto, a real extensão da biodiversidade brasileira não é conhecida e talvez nunca venha a ser, em função da enorme complexidade ecológica decorrente da grande dimensão continental e de sua plataforma marinha.

\subsection{A Política Ambiental com vista à conservação da biodiversidade}

A politica pode ser vista como um processo por meio do qual interesses levam à formulação de decisões e ações significativas que sejam levadas adiante, de modo a modificar situações dentro da sociedade. No trato das questões ambientais, 
considerando o caráter de bem comum do tema, o Estado desempenha papel dominante (SOUZA, 2000). Segundo o autor, para a implementação consistente da política ambiental, além dos objetivos e premissas a serem atingidos, devem estar previstos outros elementos: os instrumentos (como implementar) e a definição dos aspectos institucionais (quem implementa).

Em 1981, foi criada a Lei Federal $n^{\circ}$ 6.938, que dispõe sobre a Política Nacional do Meio Ambiente, instituindo, em seu Artigo $9^{\circ}$, doze instrumentos para sua implementação (VENTURA e RAMBELLI, 1996). Decorridos quase vinte anos, verifica-se que somente três foram consolidados: 1) o estabelecimento de padrões de qualidade ambiental; 2) o licenciamento de atividades potencialmente degradadoras do meio ambiente, e 3) as penalidades disciplinares ou compensatórias ao não cumprimento das medidas necessárias à preservação ou correção da degradação ambiental. Outros dois encontram-se parcialmente implementados: 1) a avaliação de impacto ambiental (somente o Estudo de Impacto Ambiental - EIA) e 2) a criação de espaços especialmente protegidos, em situação muito aquém das necessidades e extensão do Pais. Os oito restantes, dentre os quais o zoneamento ambiental, incentivos à produção e instalação de tecnologias voltadas para a qualidade ambiental, e o sistema nacional de informações ambientais, encontram-se em fase incipiente ou sem utilização corrente.

Portanto, apesar de estarem claramente definidos os objetivos e premissas da Política Ambiental, faz-se necessária a operacionalização dos seus instrumentos, para que os mesmos sejam alcançados.

A política florestal no Brasil, inserida na política ambiental, incorpora os princípios do caráter de bem comum do meio ambiente, do conceito de desenvolvimento com sustentabilidade e da conservação da biodiversidade, expliciţados, entre outros, na própria Constituição Federal de 1988, além dos diversos acordos internacionais, tais como a Agenda 21 e a Convenção sobre a Diversidade Biológica, firmados pelo País.

A Agenda 21, em seu Capitulo 11 (Combate ao Desflorestamento), ressalta a importância de salvaguardar os múltiplos papéis das florestas e áreas florestais e aponta deficiência de políticas, métodos e mecanismos em apoiar e desenvolver os papéis ecológicos, econômicos, sociais e culturais destas áreas. Em seu Capítulo 21, 
trata da conservação da diversidade biológica e refere a necessidade de adoção de medidas nacionais eficazes para a conservação dos ecossistemas (SÃO PAULO, 1992).

A Convenção sobre a Biodiversidade, também instituída na Conferência das Nações Unidas, ECO RIO - 92, visa assegurar a conservação da diversidade biológica e utilização sustentável de seus elementos, a distribuição justa e igualitária das vantagens decorrentes da exploração dos recursos genéticos, e a transferência apropriada de tecnologia, considerando todos os direitos sobre esses recursos e às tecnologias, bem como mecanismos de financiamento adequados. Para tanto, os países signatários devem elaborar estratégias, planos, programas nacionais, de forma a assegurar a sua conservação ou adaptar a esta finalidade estratégias, planos ou programas existentes, que deverão contemplar as medidas enunciadas na referida Convenção. A Convenção responsabiliza os Estados signatários pela manutenção de sua diversidade biológica e utilização sustentável de seus recursos biológicos (BRASIL, 1994).

A Convenção representa um avanço no tratamento da questão, uma vez que aborda a biodiversidade em sua totalidade: em todos os niveis (genético, espécies, ecossistemas), categorias (plantas, animais, fungos e microrganismos) e tipos de ambientes (terrestres, marinhos e de águas continentais), silvestres ou cultivados, ameaçados ou não. Também inclui todas as diferentes formas de manejo, tais como: conservação in situ (proteção e recuperação de ecossistemas, espécies e populações no local onde desenvolveram suas características distintivas, de modo a garantir a continuidade dos processos evolutivos, através de parques, reservas e outras categorias de unidades de conservação), conservação ex situ (conservação fora dos ambientes naturais, como banco de sementes, pólen, sêmen, arboretos, jardim botânico, zoológico, etc.), uso sustentável (utilização econômica mantendo seu potencial futuro) e biotecnologia, entre outras.

Embora não se possa quantificar a importância da biodiversidade em toda a sua extensão, não se justifica a ausência de medidas de prevenção ou mitigação de uma ameaça de redução ou perda da biodiversidade.

Mais de 160 países firmaram esta Convenção; contudo, ainda não está claro como deverá ser implementada. É certo que o País, engajando-se a esse instrumento 
de politica internacional, não poderá se eximir da responsabilidade de manter políticas internas de proteção dos seus recursos biológicos, posicionamento este que lhe será cobrado pelos demais signatários. Neste sentido, no mês de abril de 2000 , foi criado, pelo Decreto Federal 3.420, o Programa Nacional de Florestas - PNF, inserido na Política Nacional de Florestas, em fase inicial de implementação, e que abrange a produção sustentável de bens e serviços florestais, a conservação dos ecossistemas e melhoria da qualidade de vida (PNF, 2000).

O PNF vem ao encontro das expectativas de uma grande parcela da população, para gerir o patrimônio florestal nacional compatibilizando os interesses conservacionistas e a promoção do desenvolvimento florestal sustentável, com participação da sociedade, que será efetivada através de consultas à população para o estabelecimento de suas metas e prioridades, entre outros itens.

A título de exemplo de implementação de uma política de exploração sustentada dos recursos florestais, pode-se citar o Canadá, não como comparação, uma vez que a situação ambiental é totalmente diversa das regiōes tropicais, com baixíssima diversidade de espécies se comparada à do Brasil (CANADA, 1994,19951996,1997-1998).

No Canadá, corte raso é o regime silvícola mais utilizado, e este modo de exploração cria espaços abertos e propícios ao crescimento da sementeira. Cerca de $60 \%$ da superficie florestal explorada se regenera naturalmente, às vezes com auxilio de escarificação ou através de métodos de exploração modificados. A regeneração do restante é efetuada por semeadura ou inoculação.

Entretanto, segundo relatado, as modalidades de corte raso se modificaram muito nos últimos vinte anos, pois foi compreendida a necessidade de manutenção do habitat das espécies selvagens, de proteção do solo, de favorecimento da regeneração natural, de preservação da paisagem natural e das jovens árvores nos maciços de onde são retiradas árvores adultas. As áreas médias de corte estão diminuindo, e o regime e localização dos cortes são adaptados em função da paisagem florestal natural. Uma das modificações mais notáveis é a utilização de métodos de exploração que favorecem a regeneração natural e permitem a proteção de plantas já em desenvolvimento no sub-bosque. 
Com relação aos fatores de distúrbio nas florestas canadenses, os incêndios e os insetos são os principais; os incêndios na floresta boreal do Oeste e os insetos nas florestas do Leste, enquanto que os cortes são os principais fatores de perturbação nas florestas costeiras da Colúmbia Britânica.

Os ecossistemas em boa condição de saúde podem suportar perturbações periódicas e sua renovação pode até mesmo depender delas, como é o caso da floresta boreal.

O governo canadense está desenvolvendo estratégias de gestão da fauna e flora através de espécies indicadoras dos habitats e dos ecossistemas, e até o momento foram descritas 300.000 espécies de fauna selvagem, sendo que $2 / 3$ delas vivem nas florestas (200.000 espécies) e 117 encontram-se sob ameaça de extinção (CANADA, 1994,1995-1996,1997-1998).

\subsection{Definições e Instrumentos de Gestão dos Recursos Naturais}

Gestão ambiental é definida como o conjunto de procedimentos que visam a conciliação entre desenvolvimento e qualidade ambiental. O termo gestão, quando relacionado ao assunto meio ambiente, assume um significado muito amplo, por envolver numerosas variáveis que interagem simultaneamente. Dessa forma, para gerenciar as atividades humanas com enfoque ambiental, deve-se ter a visão do todo, a integração entre as partes e o objetivo maior onde se insere a ação ou atividade que está se desenvolvendo. Essa forma de abordagem sistêmica do meio ambiente encontra na legislação, na política ambiental e seus instrumentos, e na participação da sociedade civil, suas ferramentas de ação (SOUZA, 2000).

Para TOLBA (1982), a gestão ambiental refere-se ao gerenciamento de todas as atividades humanas que tenham impacto significante sobre o meio ambiente, determinado a partir da devida consideração das características ambientais. Segundo o autor, o mais premente objetivo da gestão ambiental é buscar a realização das necessidades humanas, considerando-se os potenciais e as restrições dos sistemas ambientais, o que inclui os recursos naturais. Relacionar a gestão ambiental ao processo de desenvolvimento traz duas novas dimensões a este: alarga o seu conceito, ao incluir como objetivo maior a qualidade ambiental, e amplia-o no tempo, por permitir que o mesmo se dê por um longo prazo em bases sustentáveis. 
Segundo MORAES (1994), a gestão ambiental qualifica a ação institucional do poder público, no sentido de objetivar a política nacional de meio ambiente. $\dot{E}$, assim, uma ação pública, empreendida por um conjunto de agentes caracterizados na estrutura do aparelho do Estado, visando a aplicação da política ambiental.

$\mathrm{Na}$ esfera institucional, a politica ambiental no País vem sendo implementada pela criação e aglutinação de órgãos com a competência de gerir o meio ambiente através da aplicação de planos, projetos, e da legislação específica, entre outros.

Nesse sentido, foi criada, em 1986, no Estado de São Paulo, a Secretaria do Meio Ambiente - SMA (Decreto Estadual n. 24.932/86), a exemplo de outros Estados da federação e da própria União, com a criação do Ministério do Meio Ambiente. Para a estruturação da SMA, foram aglutinados órgãos com tradição em atividades ambientais, entre outros, o Instituto Florestal, o Instituto Geológico, o Instituto de Botânica, a Coordenadoria de Proteção de Recursos Naturais - CPRN e a CETESB. Entretanto, cada órgão é relacionado a aspectos especificos e setoriais do meio ambiente, atuando, ainda, de forma desconectada entre si, carecendo da visão integrada e abrangente da problemática ambiental em seu conjunto e da atuação sistêmica indispensável à gestão ambiental (SÃO PAULO, 1993).

O Licenciamento e a Fiscalização Ambiental no Estado de São Paulo são realizados por duas instituições: a CETESB, que realiza o controle das fontes de poluição, e a CPRN, a quem compete o controle das atividades ou empreendimentos que se apropriam de recursos naturais. A CPRN é constituída por três Departamentos, dos quais o Departamento Estadual de Proteção de Recursos Naturais - DEPRN e o Departamento de Avaliação de Impactos Ambientais - DAIA atuam em âmbito estadual. São órgãos encarregados de ações de controle preventivo, executadas através da emissão de licenças, autorizações e pareceres técnicos, com base na legislação de proteção e conservação da vegetação natural vigente e orientação das atividades relacionadas ao uso e exploração dos recursos naturais, em especial a fauna e a flora, e do controle repressivo.

A fiscalização efetuada pelo DEPRN, ou seja, o controle repressivo, é realizada em conjunto com a Polícia Militar Florestal e de Mananciais, atuando juntos na prevenção e repressão das infrações cometidas contra o meio ambiente. 
Todo o empreendimento ou atividade que intervém de alguma forma no meio ambiente, quer por causar poluição, quer por apropriação de recursos naturais, necessita de licenciamento ambiental por parte dos órgãos competentes. Entende-se, portanto, que o Licenciamento e Fiscalização Florestal são o braço executivo da implementação das políticas na área, e o seu desempenho depende da correta aplicação das leis, regulamentações, normas e diretrizes elaboradas para o setor.

\subsubsection{Legislação relacionada à proteção de florestas e demais formas de vegetação natural}

A legislação é a ferramenta de ação mais efetiva para implementação da politica e gestão ambiental, uma vez que disciplina juridicamente a matéria e a obrigação de fazer ou não fazer. Quando aplicada no decorrer dos processos de licenciamento, tem caráter de medida preventiva, na proteção das florestas e dos recursos naturais. Nas atividades de fiscalização, é aplicada como medida corretiva, com prescrição de penas e/ou multas aos infratores.

A legislação brasileira sobre meio ambiente é recente, considerando que as Constituições brasileiras anteriores à de 1988 nada traziam de específico sobre a proteção do meio ambiente. Desde 1946, apenas se extraía orientação protecionista do preceito sobre a proteção da saúde e sobre a competência da União para legislar sobre água, florestas, caça e pesca, que possibilitaram a elaboração de leis protetoras, como o Código Florestal e os Códigos de Saúde, das Águas e de Pesca (SILVA, 1998).

\section{$>$ As Constituiçōes Federal e Estadual}

A Constituição Federal de 1988 foi a primeira Constituição a tratar deliberadamente sobre a questão ambiental e assumiu o tratamento da matéria em termos amplos e modernos. Além de trazer um capítulo específico sobre Meio Ambiente - Da Ordem Social (Cap. VI do Título VIII), a questão ambiental permeia todo seu texto, correlacionada com temas fundamentais da ordem constitucional. Portanto, para compreensão do núcleo da questão ambiental, também deve-se levar em consideração outros dispositivos da Constituição a que se referem, explícita ou implicitamente (SILVA, 1998). Por exemplo, o Art. $5^{\circ}$, inciso XXIII, onde está 
descrito que a propriedade atenderá à função social, torna plenamente compreensivel que a propriedade deva atender os anseios tanto do proprietário quanto da sociedade. Também confere legitimação a qualquer cidadão para propor ação popular que vise anular ato lesivo ao meio ambiente e ao patrimônio histórico e cultural (Art. $5^{\circ}$, inciso LXXIII). Considera, entre os bens da União, as terras devolutas, indispensáveis à preservação do meio ambiente (Art. $20^{\circ}$, Inciso II).

Nos Artigos $23^{\circ}$ e $24^{\circ}$, a Constituição reconhece a competência comum da Uniāo, Estados e Municípios para proteger paisagens naturais notáveis e o meio ambiente, combater a poluição em qualquer de suas formas, e para preservar as florestas, a fauna e a flora, e dá competência concorrente à União, Estados e ao Distrito Federal para legislar sobre florestas, caça, pesca, fauna, conservação da natureza, defesa do solo e dos recursos naturais, proteção ao meio ambiente e controle de poluição, entre outros.

Já o Artigo 186, especialmente o inciso II, agrega a utilização adequada dos recursos naturais disponíveis e preservação do meio ambiente como função social da propriedade (Art. $5^{\circ}$, inciso XXIII).

Todos esses incisos, de extrema importância, inseridos fora do núcleo que trata especificamente do meio ambiente, fazem com que a proteção ambiental constitua um direito fundamental do cidadão.

Em seu núcleo ambiental (Capitulo VI - Do meio Ambiente, Artigo 225), a Constituição de 1988 assegura o direito de todos os indivíduos viverem em um meio ambiente saudável, responsabilizando tanto o Poder Público como a coletividade a defendê-lo e preservá-lo "para as gerações presentes e futuras". Entretanto, determina ao Poder Público a responsabilidade de preservar, restaurar, manejar os processos ecológicos essenciais, a fauna e a flora e a diversidade genética, definir espaços a serem especialmente protegidos, bem como fiscalizar e controlar atividades potencialmente poluidoras ou que coloquem em risco a sua função ecológica.

Segundo MACHADO (1996), na Constituição de 1988 (Artigo 225, parágrafo $3^{\circ}$ ), foi dado um grande passo na responsabilidade penal relativa aos atos lesivos ao meio ambiente, pois, além da pessoa fisica, também a pessoa jurídica está sujeita à responsabilização criminal (BRASIL, 1999). 
A Constituição Federal de 1988 declara ainda, de antemão, como Patrimônio Nacional: a Floresta Amazônica, a Mata Atlântica, o Pantanal Mato-grossense e a Zona Costeira, ficando a exploração dessas áreas sujeita a condições que assegurem a preservação dos seus recursos naturais (Constituição Federal, Artigo 225, parágrafo $\left.4^{\circ}\right)$

Esses dispositivos constitucionais proporcionam ao cidadão a segurança de que a legislação específica venha a ser cumprida.

Na Constituição do Estado de São Paulo (SÃO PAULO, 1989), constata-se a preocupação com a instituição de uma política de meio ambiente, contemplando desde a criação de órgãos executivos até a previsão de ações conjuntas do poder público com a coletividade, buscando a preservação ambiental (Artigo 193), e dá competência constitucional à Policia Militar, pela Polícia Florestal e de Mananciais, para prevenção e repressão às infrações cometidas contra o meio ambiente (Artigo 195).

\section{$>$ O Código Florestal}

No escopo do presente trabalho, o instrumento legal mais utilizado na prática das questões relacionadas à proteção das florestas e demais formas de vegetação e, por conseqüência, de muitos atributos associados, como solo, recursos hídricos e fauna, é a Lei Federal 4.771/65, modificada pela Lei 7.803/89, que alterou o Código Florestal (VENTURA e RABELLI, 1996).

O Código Florestal traça normas sobre exploração e manejo de florestas e demais formas de vegetação existentes em nosso território, considerando-as como bens de interesse comum a todos os habitantes do Pais.

No seu Artigo $1^{\circ}$, declara que "as florestas existentes no território nacional. $\mathrm{e}$ as demais formas de vegetação, reconhecidas de utilidade às terras que revestem, são bens de interesse comum a todos os habitantes do país, exercendo-se os direitos de propriedade com as limitações que a legislação em geral e especialmente esta Lei estabelecem".

O objetivo da Lei, em seu Artigo $1^{\circ}$, é de proteger a biodiversidade das florestas e demais formas de vegetação que são próprias do País (nativas) e o 
patrimônio genético existente nas áreas florestadas, contribuindo para a proteção do solo, das águas, da fauna; em resumo, dos ecossistemas.

As limitações legais ao direito de propriedade a que se refere o enunciado versam sobre a utilização racional (sustentada) dos recursos naturais. Isso não significa que o dono não pode dispor de suas terras, mas que, ao fazê-lo, deverá seguir certas regras impostas pela Legislação, remetendo-se ao enunciado constitucional de que é função social da propriedade a utilização adequada dos recursos naturais e a proteção do meio ambiente. Desse modo, o proprietário que de alguma forma se vir legalmente impedido de utilizar parte de sua propriedade, pela existência nesses locais de características que inviabilizam sua utilização plena, não o farão por mero impedimento do Poder Público, mas sim por decorrência da própria característica do imóvel, uma vez que os rios já ali estavam, as montanhas já ali estavam, e também as nascentes. Assim, por exemplo, aqueles que adquiriram um imóvel onde existiam encostas e não podem roçá-las, já o adquiriram com aquela restrição, pois as encostas ali estavam e necessitam das matas protetoras para evitar a erosão do solo e assoreamento dos rios (DUARTE, citado por SILVA, 1998).

Dentre as disposições do Código Florestal mais utilizadas na prática do Licenciamento e Fiscalização, destacam-se os Artigos $2^{\circ}$ e $3^{\circ}$, que determinam a localização das florestas e demais formas de vegetação consideradas de preservação permanente, e o Artigo 16, que dispõe sobre a permissão de exploração com restrições de manutenção de uma Reserva Florestal na propriedade.

No Artigo $2^{\circ}$, no texto "considera-se de preservação permanente, pelo efeito desta Lei, as florestas e demais formas de vegetação situadas.......", encontra-se o conceito de que as limitações impostas perpassam a qualidade da vegetação da cobertura e abrangem as áreas dentro das metragens determinadas na Lei, independentemente de serem ou não florestadas. Assim, são consideradas em razão da localização geográfica e do papel de proteção que desempenham. As áreas consideradas de preservação permanente são aquelas elencadas nas alineas daquele Artigo, quais sejam: ao longo de rios, ao redor de nascentes e olhos d'água, ao redor de lagos artificiais ou naturais, nos topos de morro, nas encostas de montanhas, nas áreas com altitudes superiores a 1.800 metros, nas restingas, etc.. 
A Resolução CONAMA n. ${ }^{\circ} 004 / 85$ (BRASIL, 1985) transforma em Reservas Ecológicas as formações floristicas e as áreas de florestas de preservação permanente, além daquelas descritas no Artigo $2^{\circ}$ do Código Florestal, que inclui outras situações geográficas (montanhas, serras, veredas, entre outras), o que possibilita salvaguardar, na maior parte das vezes, na atividade de licenciamento, a vegetação natural associada a estas áreas acidentadas.

Em seu Artigo 18, a Lei 4771/65 indica a necessidade de revegetação ou replantio com espécies nativas das áreas de preservação permanente.

Portanto, da leitura do conjunto de Artigos do Código Florestal relativo às áreas de preservação permanente (Artigos $2^{\circ}, 3^{\circ}$ e $18^{\circ}$ ), subtrai-se que, além da manutenção da vegetação de preservação permanente, a Lei determina a criação de florestas nesses locais, instituindo a obrigatoriedade de plantar, nos casos onde seja necessário (MORAES, 1999), exatamente porque a referida vegetação destina-se a proteger recursos naturais essenciais.

Qualquer proprietário poderá averbar sua Reserva Florestal, desde que seja constatado pela autoridade florestal ganho ambiental ("interesse público"), segundo o Artigo $6^{\circ}$ - "O proprietário de floresta não preservada nos termos dessa Lei, poderá gravá-la com perpetuidade, desde que verificado o interesse público pela autoridade florestal." Na prática, poucos o fazem de forma voluntária como prescreve o Artigo, uma vez que, no entendimento (sentimento) geral da população, a averbação de Reserva Legal constitui uma intervenção do Estado na propriedade privada; mas é oportuno lembrar que o parágrafo $2^{\circ}$ do Artigo 16, no mesmo Código, expressa um comando claro na obrigatoriedade da aludida averbação.

O Artigo $9^{\circ}$ do Código Florestal diz que "as florestas particulares, quando indivisas com outras, sujeitas a regime especial, ficam subordinadas às disposições que vigorarem para estas". Entende-se por "regime especial" as limitações impostas pelo Código Florestal às áreas florestadas, como por exemplo as reservas legais, florestas de preservação permanente. Segundo o enunciado, numa floresta contígua a uma Reserva Legal, não será permitida, por exemplo, autorização à corte raso, bem como nenhuma autorização além daquelas possíveis a esta (MORAES, 1999). Tecnicamente, tal determinação encontra fundamento na formação de fragmentos florestais mais amplos ou para conexão entre dois fragmentos, independentemente do 
limite dominial, para manutenção do fluxo de fauna e dos habitats. Entretanto, na prática este não é um dispositivo muito utilizado, talvez pela pontualidade de visão quando do Licenciamento.

O Artigo $10^{\circ}$ introduz limitações ao corte raso de florestas protetoras de áreas declivosas (declividade de 25 a 45\%), porém tolera a exploração de maneira racional, desde que exista floresta. Neste trabalho, considera-se essas declividades bastante críticas, muito acentuadas, para ficarem a descoberto de cobertura arbórea; porém, quando a floresta não existe nessas encostas, não se dispõe de instrumentos para dissuadir o proprietário a abandonar o uso e deixar a floresta se regenerar naturalmente. Entende-se que, nessa faixa de declividade, outros fatores de análise deveriam ser somados (vulnerabilidade do solo, drenagem e entorno), quando do Licenciamento.

O outro Artigo muito utilizado nas atribuições do Licenciamento Florestal, e também o que gera mais questionamentos por parte dos proprietários, é o Artigo 16, que institui a obrigatoriedade de manutenção de uma reserva florestal de, no mínimo, $20 \%$ da área total da propriedade para concessão de autorização de desmatamento: “As florestas de dominio privado, não sujeitas ao regime de utilização limitada e ressalvadas as de preservação permanente, previstas nos Art. $2^{\circ}$ e $3^{\circ}$ desta Lei, são suscetíveis de exploração, obedecidas as seguintes restrições:...." Apresenta, então, quatro Incisos, delimitando regiões do país, e permitindo a derrubada, desde que respeitado o limite de manutenção de, no mínimo, $20 \%$ ou $50 \%$ da área da propriedade, conforme a região, com cobertura arbórea localizada à critério da autoridade competente.

No caso do Estado de São Paulo, aplica-se o disposto no inciso (a) do Código Florestal, ou seja, respeitando-se um mínimo de $20 \%$ da área de vegetação nativa em cada propriedade. Com o objetivo de se evitar a alteração da finalidade da área, o parágrafo $2^{\circ}$ do mesmo Artigo determina a averbação da Reserva Legal na matrícula do imóvel, sendo vedada sua alteração, nos casos de transmissão, a qualquer título.

No sentido de coibir maior fragmentação dos maciços florestais, quando dos desmembramentos de propriedades, somada à obrigatoriedade e inalterabilidade de averbação de Reserva Legal referida no Artigo 16, ficou estabelecido, através da Portaria DEPRN 001/85, que a área florestal mínima de $20 \%$ de uma propriedade é 
calculada em função da gleba total, tomando-se o ano de 1985 como referência, ou seja, considerando toda cobertura florestal existente na área referida na matricula original até o ano de 1985 ou anterior a ele. Dessa forma, se um proprietário adquiriu uma área em 1991, desmembrada de gleba maior e requer ao DEPRN uma autorização de corte raso, o minimo de $20 \%$ de Reserva Legal será calculado em relação à matricula de 1985 (gleba-mãe). Caso não exista na gleba-mãe no mínimo $20 \%$ de remanescente florestal, averbado na matrícula do imóvel ou não, o corte raso na gleba desmembrada somente poderá ser concedido após a complementação do percentual mínimo proporcional à área da gleba original, observando-se, em qualquer caso, o minimo legal.

Na prática, em sua grande maioria as Reservas Legais somente são averbadas quando o proprietário procura o DEPRN para requerer autorização de desmatamento ou quando autuado, para cumprir requisitos do Ministério Público, como parte do Termo de Ajustamento de Conduta, ou ainda como resultado de uma Ação Civil Pública movida para tal finalidade. Via de regra, quando são obrigados a averbar a Reserva Legal, os proprietários sentem-se lesados no seu direito de propriedade. Remete-se, então, novamente ao Artigo constitucional da função social da propriedade. Das fontes citadas, nenhum autor questiona a obrigatoriedade de manutenção de Reserva Florestal. A discussão maior situa-se no âmbito da gratuidade dessa obrigação. Segundo MACHADO (1996), essa é uma obrigação sem direito à indenização, enquanto outros (MORAIS, 1999), contrariamente, acreditam que da mesma deva o proprietário ser indenizado.

Atualmente, não há floresta que possa ser livremente explorada, porque qualquer tipo de exploração depende de autorização ou licença do poder público.

É obrigatória a autorização da autoridade competente, no caso de São Paulo, o DEPRN (Artigo 19 do Código Florestal), para qualquer tipo de exploração (corte raso ou não) de vegetação natural a partir de estágio inicial de regeneração, ou seja, acima de $1,5 \mathrm{~m}$ de altura e $3 \mathrm{~cm}$ como diâmetro de caule ao nível do solo (Res. CONAMA 01/94). Abaixo desse padrão (vegetação pioneira) o corte é livre, desde que a área não seja de relevante interesse ambiental e considerada de preservação permanente. 
Já as florestas plantadas, desde que cultivadas fora de áreas consideradas de preservação permanente e de reserva legal, são livres para o corte, conforme preconiza o Artigo 12 do Código Florestal. Segundo entendimento de MORAIS (1999), o licenciamento pode ser exigido no sentido da verificação do fato, bem como nos casos de comercialização, pois a mesma sem a devida licença implicará na responsabilidade do adquirente, portanto, a necessidade do monitoramento da exceção.

Atualmente, alguns juizes também têm exigido a averbação da Reserva Legal quando das ações de Retificação Judicial de Ȧrea. Entretanto, esse procedimento ainda não está bem estabelecido, faltando ao serviço público maior agilidade no sentido de responder a essa nova demanda, de forma a não desmobilizar o juizo na continuidade dessa prática. Afora essas situações, existem raros casos em que o proprietário se apresenta voluntariamente para averbar sua reserva legal, embora a mesma seja obrigatória.

A averbação da Reserva Legal acima do minimo exigido, ou seja, mais do que $20 \%$ da área total da propriedade, é conseguida com muita dificuldade, quase sempre associada à autorização de corte raso de áreas grandes ou de vegetação com padrão de desenvolvimento mais expressivo.

Apesar da averbação da Reserva Legal ser um bom instrumento para coibir a degradação total dos habitats florestais, sua prática acaba fragmentando os remanescentes, ocorrendo a criação de muitas "ilhas em meio a um mar contendo atividades agropecuárias, urbanização, mineração e suas conseqüências, que servem como barreira para as espécies que não possuem sistema de deslocamento aéreo privilegiado" (LINBERG, citado por PIRES, 1995).

O Artigo 19 outorga a autoridade ao IBAMA, nos casos de exploração de florestas e de formações sucessoras. Segue-se comentário sobre o referido Artigo: "A conservação de uma floresta não quer dizer só imobilização, mas também o aproveitamento sustentado, que é de vital importância. $O$ manejo florestal sustentado consiste num modo de exploração florestal de forma que se respeitem as características básicas dos ecossistemas, pela sustentação dos processos ecológicos essenciais e da diversidade genética da área, levando-se em conta que cada floresta é o lugar de diversos nichos ecológicos, cuja destruição ou perturbação importam para 
o desequilibrio, não raro, fatal para espécies daquele habitat. $O$ manejo florestal sustentado propicia rendimento sustentado, que corresponde ao incremento da floresta, rendimento inesgotável porque mantém sua fonte de sustentação permanente. Vale observar que o desequilíbrio dos ecossistemas não provém apenas do corte irracional de árvores, mas também pela introdução de espécies exóticas. Como se pode observar, sob as florestas exóticas plantadas pouco proliferam herbáceas e as demais formas de vegetação de sub-bosque que verificamos nas florestas nativas". Este texto, transcrito na íntegra, é de autoria do eminente jurista José Afonso da Silva (SILVA, 1998), e foi assim utilizado no sentido de demostrar o embasamento e responsabilidade de um professor de Direito Constitucional, discorrendo sobre um tema diverso à sua especialidade, para alertar sobre as formas inadequadas de exploração florestal e de reflorestamento, que encontrava fundamento no enunciado do Artigo 19 do Código Florestal, anterior à sua modificação, que assim dizia: "Visando ao maior rendimento econômico, é permitido aos proprietários de florestas heterogêneas transformá-las em homogêneas, executando trabalho de derrubada a um só tempo ou sucessivamente de toda vegetação a substituir desde que assinem, antes do início dos trabalhos, perante a autoridade competente, termo de obrigação de reposição de tratos culturais". Neste texto legal, o rendimento econômico era fator primordial, autorizando o corte raso de vegetação nativa e estimulando o proprietário a destruir a floresta (floresta natural, mata virgem) heterogênea, substituindo-a por homogênea com vistas à obtenção de lucros, destruindo os ecossistemas relacionados e, conseqüentemente, a diversidade genética neles envolvidos e deles subsistentes.

O texto do Art. 19 foi reeditado duas vezes (Lei Federal 7.511/86 e Lei Federal 7.803/89) e apresenta hoje uma intenção mais ecológica e compatível com a Constituição de 1988. A redação atual é a seguinte: "Artigo 19 - A exploração de florestas e de formações sucessoras, tanto de domínio público quanto de domínio privado, dependerá de aprovação prévia do IBAMA, bem como da adoção de técnicas de condução, exploração, reposição florestal e manejo compativeis com os variados ecossistemas que a cobertura arbórea forme.

Parágrafo Único - No caso de reposição florestal, deverão ser priorizados projetos que contemplem a utilização de espécies nativas." 


\section{$>$ Outras Leis e Regulamentações de Proteção a Florestas}

As formações de Mata Atlântica, tão raras na região de estudo, encontram-se bem protegidas pela Legislação através do Decreto Federal 750/93, que dispõe sobre - corte, exploração e supressão de vegetação primária ou nos estágios médios e avançados de regeneração, e várias regulamentações posteriores (SÃO PAULO, 1997).

Com exceção da Resolução Conjunta SMA/IBAMA/SP 2/94, alterada pela Resolução Conjunta SMA/IBAMA 5/96, que abriu precedentes autorizando a supressão de vegetação de restinga, possibilitando a ocupação e parcelamento do solo, realizado de forma visivelmente predatória, sobretudo nas praias do litoral norte de São Paulo, as várias regulamentações posteriores estabeleceram ou definiram claramente parâmetros para análise dos estágios de regeneração, bem como procedimentos preservacionistas para proteção de corredores de fauna entre remanescentes florestais (Resolução CONAMA 10/93; Resolução CONAMA 01/94/93; Resolução CONAMA 07/96; Resolução CONAMA 09/96) (SÃO PAULO, 1997).

Na Resolução CONAMA 9/96, que versa sobre as áreas que se prestem a corredores entre remanescentes de Mata Atlântica, verifica-se a possibilidade e a indicação da avaliação macro-ambiental dos ecossistemas, considerando para tanto os elementos da ecologia da paisagem (heterogeneidade), o que se considera um grande avanço, sobretudo no que diz respeito às intervenções necessárias à sua recomposição florística com espécies nativas .

As florestas e demais formas de vegetação natural em várzeas não apresentam proteção legal suficiente, através do Decreto Estadual $n .^{\circ} 39.473 / 94$ e da Resolução Conjunta SAA/SMA/SRHSO n. ${ }^{\circ}$ 4/94, que prevêem a utilização dessas áreas em $80 \%$, desde que cumpridas algumas exigências técnicas, tais como parecer da Secretaria da Agricultura e manutenção de $20 \%$ da várzea como Reserva Legal.

O Cerrado, uma das fisionomias mais ameaçadas do Brasil e do Estado de São Paulo, é o principal bioma na área de estudo, município de Descalvado, e está desaparecendo, apesar do reconhecimento cientifico do seu valor em termos de manutenção de diversidade biológica. Não existe Legislação específica para sua 
proteção. No Código Florestal, esse bioma é referido como forma de vegetação que é passivel de autorização à corte raso em $80 \%$ da área.

No Estado de São Paulo, foi criado um Grupo de Apoio ao Licenciamento das Áreas de Cerrado (Resolução SMA n. ${ }^{\circ}$ 55/95), como órgão consultivo, que dá pareceres para o licenciamento à corte raso de áreas maiores que 20 hectares em zona rural, 10 hectares em zona urbana, ou faça parte de fragmentos contínuos superiores a 50 hectares em qualquer situação. O Grupo do Cerrado é formado por especialistas de diferentes órgãos da Secretaria de Estado do Meio Ambiente: Instituto de Botânica, Instituto Florestal, Departamento de Avaliação de Impactos Ambientais DAIA e Departamento Estadual de Proteção de Recursos Naturais - DEPRN. Este grupo leva em consideração, também, a lista oficial de espécies da fauna ameaçadas de extinção (Decreto Estadual 42.838/98), que é o instrumento legal que tem auxiliado na conservação dessas áreas. Praticamente todos os pareceres emitidos por esse grupo de especialistas foram acatados no âmbito do DEPRN, para concessão de Licenciamento (SÃO PAULO, 1998).

\section{> Lei Orgânica do Município de Descalvado - Artigos referentes à proteção ambiental \\ O município de Descalvado apresenta em sua Lei Orgânica, promulgada em} abril de 1990, todo um capítulo voltado à proteção ambiental, que segue o mesmo modelo da Constituição Estadual, delegando ao poder público a obrigação de propor politicas ambientais e, entre outras, a de "promover e manter o inventário e o mapeamento da cobertura vegetal nativa, visando à adoção de medidas especiais de proteção, bem como incentivar o reflorestamento, em especial às margens dos rios e córregos, visando a sua perenidade". O Artigo 151 dessa Lei determina que são espaços especialmente protegidos alguns atributos da paisagem local, sejam eles: o Salto Dom Lino (no rio do Pântano), o Morro da Janelinha e a Serra do Descalvado.

Além dos dispositivos supra citados, o Artigo 152 institui áreas de preservação permanente, tais como as margens de rios, córregos e nascentes, limitações estas impostas pelo Código Florestal, acrescentando ao mesmo "os cursos dos Rios Bonito e do Pântano", as duas principais sub-bacias do município, como objetos de proteção máxima. 
Comparado a outros municípios da região, Descalvado apresenta posições avançadas com relação à postura ambiental, haja vista a criação da APA de Descalvado (Lei $\mathrm{n}^{\circ} 1.600$ de junho de 1996), com perímetro muito próximo daquele proposto por OLIVEIRA (1995), tendo sido alterado sobretudo nas áreas de cerrado, onde se desenvolve a atividade de extração de areia da Mineração Descalvado. $O$ Município ainda está propondo à esfera estadual que a APA municipal seja incorporada à APA Estadual - Perímetro Corumbataí (Decreto $n^{\circ}$ 20.960/83), contígua e com os mesmos atributos de proteção, sejam eles as "cuestas", áreas de recarga de aqüifero e a proteção da biota local (cerrado e fauna associada).

\section{$>$ Lei de Crimes Ambientais}

Com a aprovação da Lei de Crimes Ambientais - Lei 9.605/98, as condutas lesivas ao meio ambiente passaram a ser punidas civil, administrativa e criminalmente. Vale dizer, uma vez constatada a degradação ambiental, o infrator (poluidor ou degradador), além de ser obrigado a promover sua recuperação, através de procedimento judicial civil, responde com o pagamento de multas pecuniárias e com processo criminal.

Grande parte das contravenções contidas nas alíneas (a) a (q) do Artigo 26 do Código Florestal foram revogadas e transformadas em crimes, tais como: destruir, danificar, cortar árvore, penetrar com instrumentos de caça e extrair minerais em florestas de preservação permanente; causar danos a Unidades de Conservação; usar de fogo em florestas; transportar ou guardar madeira sem licença, entre outros. Apenas a alíneas $\mathrm{g}$, j e 1 não foram revogadas, e continuam como contravenção. As demais passaram a ser crimes pela Lei $9.605 / 98$, com penas previstas de detenção ou multa, ou ambos.

Em 1985, foi editada a Lei Federal 7.374, que disciplinou a ação civil pública por responsabilidade de danos causados ao Meio Ambiente, entre outros, denominada Lei dos Direitos Difusos, que, com base no Artigo $1^{\circ}$ da Lei Federal $n^{\circ}$ $6.938 / 81$, obriga o poluidor a indenizar ou reparar o dano ambiental independente da existência de culpa, criando-se, dessa forma, a responsabilidade objetiva.

A Ação Civil Pública foi, sem dúvida, o passo mais importante dado nos últimos anos para a defesa do meio ambiente (Lei 7.347/85). Ela é proposta no foro 
onde ocorrer o dano, cujo juízo terá competência funcional para processar e julgar a causa. A regra é simples, com uma ressalva: quando figurar como autora, ré, assistente ou opoente a União Federal, Autarquia Federal ou Empresa Pública Federal, a competência será da Justiça Federal. Entretanto, não sendo o local dos fatos sede de Vara Federal, poderá a ação civil pública ser proposta pela Justiça Estadual, com recurso para o Tribunal Federal competente (FREITAS e FREITAS, 1991).

O Art. $5^{\circ}$ da Lei $7.347 / 85$, supra mencionada, atribui legitimidade para propor a ação civil pública ao Ministério Público Estadual, União, Estados, Municípios, Autarquias, Empresas Públicas, Fundações, Sociedades de Economia Mista e Associações. O órgão mais adequado para o relevante mister sem dúvida é o Ministério Público, gozando de independência e garantias estampadas na norma constitucional, e que dispõe de meios para fazer valer os dispositivos da lei. Portanto, um simples requerimento ao Promotor Público da Comarca poderá ser o suficiente para prevenir, reprimir ou recuperar sério dano ao meio ambiente (FREITAS e FREITAS, 1991).

Dependendo da Comarca, a maior parte das infrações ambientais são resolvidas no Ministério Público, sem necessidade da propositura da Ação Civil Pública, através de Termo de Ajustamento de Conduta - TAC, firmado pelo causador do dano ambiental com a Promotoria, onde são fixadas as medidas de reparação, com prazos e multas estabelecidas em caso de descumprimento do Termo. Geralmente, o teor técnico desses TACs é aquele que consta do Laudo de Dano Ambiental efetuado pelos técnicos do DEPRN, na figura de assistente técnico ou perito. Caso não seja firmado ou cumprido o referido Termo, a Ação Civil Pública será proposta pelo Promotor no foro local, e o juiz irá processar e julgar a causa, sempre observando o instituto da responsabilidade civil objetiva pelo dano ambiental, conforme disposto no Artigo 14, parágrafo $1^{\circ}$, da Lei $n^{\circ} 6.938 / 81$.

Nos últimos anos, o Ministério Público, de uma forma geral, através de suas Curadorias do Meio Ambiente, vem atuando com muita competência na fiscalização do cumprimento dos ditames legais em defesa do meio ambiente. 


\subsubsection{Licenciamento e Fiscalizaçāo dos Recursos Naturais}

Em seus Artigos 19 e 22, o Código Florestal dispõe sobre a competência da fiscalização e possibilidade de delegação através de convênios celebrados com o órgão executivo federal.

A competência para fiscalização do Código Florestal foi dada pelo DecretoLei 289/67, Artigo $3^{\circ}$, IX ao extinto Instituto Brasileiro de Desenvolvimento Florestal - IBDF, mais tarde substituído pelo IBAMA, como órgão executor. No Artigo $5^{\circ}$ do Decreto de sua criação, O IBDF recebeu autorização para celebrar convênios com entidades públicas ou privadas, face às dificuldades de atuar em todo território nacional. Por esse instrumento de convênio, a fiscalização no Estado de São Paulo passou a ser efetuada, pela delegação do órgão federal, por órgão ambiental da administração direta do Estado, atualmente o Departamento Estadual de Proteção de Recursos Naturais - DEPRN, da Secretaria de Estado do Meio Ambiente, em conjunto com a Polícia Militar Florestal e de Mananciais.

MACHADO (1996) acredita que o poder de polícia, embora possa ser atribuído a funcionários da administração indireta, é mais eficaz se exercido por funcionário público com garantias de estabilidade na relação empregatícia, considerando toda sorte de pressões exercidas sobre o técnico que de alguma forma se contrapõe ao interesse privado, em defesa do coletivo.

Ainda sob esse aspecto, o órgão do Ministério Público deve ser buscado como garantia da prevalência do trabalho imparcial do técnico face a interesses privados que, nessas disputas, quase sempre são prejudiciais ao meio ambiente, uma vez que o conceito do ideal de desenvolvimento sustentável nem sempre é respeitado.

Face ao exposto, pode-se extrair que, apesar da clara intenção legal de manutenção de todas as áreas com relevante interesse à conservação da diversidade biológica, ainda são autorizadas à corte raso diversas formações florestais que tecnicamente deveriam ser mantidas. Nesse sentido, entende-se que a implementação de outros instrumentos de gestão previstos em Lei, tais como instrumentos econômicos de estimulo à manutenção de áreas florestadas, as Unidades de Conservação, o Plano Diretor, o Zoneamento Ambiental, entre outros, seriam de extrema validade na prática do Licenciamento, pois através deles agrega-se valores 
ambientais que não são considerados quando da análise pontual das áreas florestais. Na seqüência, serão destacados aqueles considerados mais relevantes.

\subsubsection{Instrumentos econômicos para implementação da política ambiental}

Diversos instrumentos de ordem econômica, como por exemplo, aplicação de taxas (princípio do poluidor/pagador) e subsidios (financiamentos a baixo custo) vêm sendo utilizados em várias partes do mundo como forma de incentivar os agentes poluidores a adotarem medidas de redução da degradação ambiental (ALMEIDA, 1998). Diferem dos instrumentos de regulação direta ou controle, como por exemplo, estabelecimento de padrões de qualidade e limites de emissão; entretanto, a nosso ver, as suas aplicações não são incompatíveis entre si, no que se refere à conservação dos recursos naturais e recuperação de áreas de vegetação natural. Por exemplo, atualmente são autorizadas à corte raso áreas florestais excedentes aos padrões legais estabelecidos (mecanismo de regulação direta), mesmo que estas sejam importantes para as condições do entorno ou para manutenção das qualidades ambientais no local. Caso houvesse uma valoração econômica para manutenção dessas áreas florestadas em percentual acima do mínimo legal exigivel, o proprietário privado e as administrações públicas não teriam interesse em suprimi-las. Existem algumas pequenas iniciativas nesse sentido, que não atingem o resultado esperado, que seria o de estimular a manutenção das áreas florestadas, bem como sua recuperação. Dentre elas, pode-se citar:

- Isenção de Imposto Territorial Rural - ITR das áreas relativas à Preservação Permanente - APP, às Reservas Particulares do Patrimônio Natural - RPPN e das Reservas Legais Averbadas (MINISTÉRIO DA FAZENDA, 1997).

- Recursos financeiros provenientes do FEHIDRO alocados pelos Comitês de Bacias Hidrográficas para projetos de recomposição ambiental das bacias hidrográficas, como por exemplo, recomposição das matas ciliares .

- Reposição florestal: todos os consumidores de madeira são obrigados a plantar área equivalente à madeira cortada, com o objetivo de não reduzir o patrimônio florestal. Muitos consumidores que não podem ou não desejam plantar podem recolher ao IBAMA, ou a Associações de Reposição Florestal cadastradas pelos órgãos competentes, os valores correspondentes à obrigação de plantar. Estes 
valores deverão ficar no Estado, para utilização exclusiva em plantio de florestas de objetivos ambientais e sociais (BRANDÃO, 1997).

- ICMS Ecológico: verba repassada aos municipios em função da manutenção, em seus limites, de áreas com vegetação natural preservadas.

Encontra-se em pauta, na esfera federal, a alteração do Código Florestal. Dentre outras, está em discussão a possibilidade do proprietário privado vender ou locar áreas florestais que excedam o percentual mínimo de $20 \%$ para aqueles que não disponham de áreas florestadas para constituir sua reserva florestal. Entende-se que tal medida irá diminuir substancialmente, se não terminar, com os requerimentos de desmatamento no Estado de São Paulo, que, pelo aumento da demanda, passarão a ter uma intensa valorização comercial, uma vez que a cobertura florestal total alcança no máximo cerca de $7 \%$ da superficie.

\subsubsection{Sistemas de Unidades de Conservação - Instrumento para conservação da} biodiversidade in situ.

A criação de Unidades de Conservação (UC) tem sido adotada pelos governos, em todos as esferas (federal, estadual e, sobretudo, municipal) para implementação de políticas de conservação da biodiversidade, com a finalidade de diminuir o ritmo de perda das espécies. Nestas Unidades de Conservação, busca-se manter os ambientes e as inter-relações existentes entre as espécies ali presentes, além dos processos associados à sua dinâmica de desenvolvimento. Têm sido criadas em todos os países do mundo e em número crescente, ao longo dos anos. As Unidades de Conservação promovem também a conservação de unidades paisagisticas significativas e, em algumas categorias, propiciam a manutenção do modo de vida de populações humanas tradicionais. A conservação in situ da biodiversidade visa manter os ecossistemas e habitats naturais com populações viáveis de espécies em seus meios naturais de ocorrência. De um modo geral, as Unidades de Conservação são grandes áreas naturais (terrestres ou marinhas) pouco alteradas pela ação humana, representativas dos ecossistemas existentes nas diferentes partes do planeta (BRITO et al., 1999).

Para DIEGUES (1994), a forma como foram estabelecidas as áreas protegidas desconsiderou a presença e o conhecimento de populaçōes tradicionais, sem consulta 
às regiões envolvidas, tampouco às populações afetadas em seu modo de vida. Segundo o autor, a criação das Reservas Extrativistas reflete as tendências internacionais, cujos principios aliam a conservação da biodiversidade e a inserção econômica das populações tradicionais, e substitui a concepção de proteção integral pela postura de que, para assegurar a diversidade biológica, é imprescindível o conhecimento e inserção das populações locais. $O$ autor ressalta a necessidade de conhecer melhor as relações entre a manutenção da diversidade biológica e a conservação da diversidade cultural e conclui que existe necessidade de interdisciplinaridade entre cientistas das áreas das ciências biológicas e das ciências humanas, quando da avaliação de uma área a ser declarada unidade de conservação.

As Unidades de Conservação brasileiras estão subtilizadas e precariamente protegidas e manejadas (DIAS, 2000). De acordo com BRITO et al. (1999), contribuem para a qualidade de conservação:

- o status da biodiversidade da área, quando esta foi definida como Unidade de Conservação;

- o grau de ameaça a que está afeta;

- o grau de conhecimento científico que se tem sobre a mesma;

- o manejo a que está submetida; e

- o grau de prioridade que a unidade merece no sistema.

Neste sentido, informações que tratam do formato das unidades, situação fundiária, ocupação e uso do solo na área de entorno, bem como da infra-estrutura para pesquisa e visitação, são muito importantes.

Segundo PIRES (1999), conservar ou preservar a biodiversidade não significa simplesmente manter um determinado número de espécies em uma Unidade de Conservação, considerando que cada uma destas espécies continuará desempenhando sua função no ecossistema. A autora entende que a proteção da diversidade biológica requer um compromisso de proteção de sistemas inteiros, onde grandes áreas devam ser protegidas em uma estratégia inter situ, ainda que apenas algumas sejam mantidas como Unidades de Conservação. Aponta para a necessidade do planejamento da conservação das paisagens regionais, que necessita contemplar qualquer tamanho de área natural que possa fazer parte desse sistema de proteção. 
São consideradas Unidades de Conservação, entre outras:

- Parques Nacionais, áreas geográficas extensas e delimitadas, dotadas de atributos excepcionais, objetos de preservação permanente, submetidas à condição de inalienabilidade e indisponibilidade no seu todo (Decreto Federal $n^{\circ} 84.017 / 79$ );

- Parques Estaduais e Municipais, criados com a finalidade de resguardar os atributos excepcionais da natureza, conciliando a proteção integral da flora, da fauna e das belezas naturais com a utilização para objetivos educacionais, recreativos e científicos (Lei n. ${ }^{\circ} 4.771 / 65$ - Código Florestal);

- Estações ou Reservas Ecológicas, que são áreas representativas de ecossistemas brasileiros, destinadas à realização de pesquisas básicas e aplicadas de Ecologia, à proteção do ambiente natural e ao desenvolvimento da educação preservacionista, onde $90 \%$ ou mais da área total será destinada, em caráter permanente, à preservação integral da biota. São assim consideradas as florestas e demais formas de vegetação consideradas de preservação permanente no Artigo $2^{\circ}$ do Código Florestal, bem como as que assim forem estabelecidas por ato do poder público pela União, Estados e Municípios, em terras de seus domínios (Lei 6.938/81, Decreto Federal n. ${ }^{\circ} 89.336 / 81$ e Resolução CONAMA n. ${ }^{\circ}$ 04/85);

- Reservas Particulares do Patrimônio Natural (Reservas Legais): imóvel de domínio privado, por destinação de seu proprietário e em caráter perpétuo, onde, no todo ou em parte, sejam identificadas condições naturais primitivas, semiprimitivas, recuperadas, ou cujas caracteristicas justifiquem ações de recuperação pelo seu aspecto paisagístico ou para preservação do ciclo biológico de espécies da fauna ou da flora nativas do Brasil (Decreto Federal n. ${ }^{\circ}$ 98.914/90);

- Áreas de Proteção Ambiental: unidades de conservação, destinadas a proteger e conservar a qualidade ambiental e os sistemas naturais existentes, visando a melhor qualidade de vida da população local e também objetivando a proteção dos ecossistemas regionais. São implementadas por Zoneamento EcológicoEconômico - ZEE, abrangem áreas de domínio privado, e apresentam relativa proteção aos ecossistemas (Resolução CONAMA 10/88).

A situação da representatividade dos biomas em Unidades de Conservação no Brasil encontra-se na Tabela 1. Segundo os autores, há uma grande disparidade em 
termos de número de Unidades de Conservação, de extensão coberta e efetividade de conservação da biodiversidade, dentre outras (BRITO et al., 1999).

Tabela 1 - Representatividade dos biomas brasileiros no Sistema Nacional de Unidades de Conservação Federal (seg. BRITO et al., 1999).

\begin{tabular}{cc}
\hline Biomas & \% do Território do Bioma sob Proteção \\
\hline Amazônia & 10 \\
Cerrado & 0,2 a 0,7 \\
Caatinga & menos de 1 \\
Mata Atlântica & 2 \\
\hline
\end{tabular}

Existem oitenta e cinco Unidades de Conservação no Estado de São Paulo, perfazendo uma área total de $897.121,69$ ha, equivalente a 3,14\% do território estadual. Todas são geridas pela Secretaria de Estado do Meio Ambiente de São Paulo. Excetuam-se deste total as Áreas de Proteção Ambiental - APAs, que abrangem áreas de dominio privado e devem ser implementadas por ZEE, apresentando proteção relativa.

\section{$>$ Unidades de Conservação no domínio do cerrado}

O cerrado abriga uma biodiversidade ímpar, e a região do município de Descalvado é um dos últimos e poucos locais do Estado onde pequenas manchas são encontradas mais ou menos conservadas. Destacam-se aqui alguns dados relativos a esse bioma, considerando o seu elevado interesse regional.

O cerrado apresenta físionomias e composição floristica variáveis, sistemas subterrâneos muito desenvolvidos e/ou profundos, geralmente ocorrendo sobre solos álicos, altamente intemperizados como latossolos e areias quartzosas, ou ainda cambissolos em paisagens morfogeneticamente envelhecidas, sob climas estacionais. As fisionomias variam de desde florestas (cerradão) até semelhantes a pradaria (campo limpo), de aspecto geral escleromorfo. As árvores e arbustos apresentam troncos retorcidos, casca grossa, folhas grandes e pilosas, podendo ser deciduo na estação seca. As ervas predominantemente graminóides cespitosa, e subarbustos geralmente perdem total ou parcialmente a parte área na estação seca. A sinusia 
arbórea, quando presente é rica em espécies de Leguminosae, Bigoniaceae, Myrtaceae, Melastomataceae, entre outras. A sinusia arbustiva, quando presente, é rica em espécies de Rubiaceae, Melastomataceae, Verbenaceae, entre outras. A sinusia herbácea, quando presente é rica em espécies de Poaceae (Graminae), Asteraceae (Compositae), Cyperaceae, entre outras. Encontram-se elementos de fauna freqüentemente associados, as seguintes espécies: tamanduá bandeira (Myrmecophaga trydactyla), tatu-canastra (Priodontes giganteus), cervo (Blastocerus dichtomus), lobo-guará (Chryscyon brachyurus), onça pintada (Pantera onca), lontra (Lutra platensis), entre outras (Anexo 1 da Resolução SMA-55, de 13/10/1995) (SĀO PAULO, 1997).

No Brasil, os cerrados abrangem cerca de $1 / 4$ do território nacional, sendo o segundo maior bioma do Brasil e da América do Sul, ocupando mais de 200.000.000 mil ha e ocorrendo predominantemente na região Centro-Oeste. Abrigam um rico patrimônio de recursos naturais renováveis adaptados às duras condições climáticas, edáficas e hidricas, que determinam sua própria existência. São mais de $2.000 \mathrm{mil}$ espécies de plantas lenhosas nativas, um número ainda maior de espécies herbáceas. Por exemplo, são mais de 233 espécies de orquideas só no Distrito Federal e um número ainda desconhecido de animais. Só no Distrito Federal estão registradas mais de 430 espécies de aves. Os cerrados estão mais ameaçados e são menos conhecidos que a Amazônia (DIAS, 1996).

No Estado de São Paulo, as formações de cerrado não são continuas, ocorrendo como encraves à floresta mesófila, que é o bioma predominante. Embora fossem encontrados em expressões mais contínuas nas Regiões Administrativas de Ribeirão Preto, Sorocaba, Bauru e Campinas, atualmente verifica-se a sua ocorrência mínima em locais determinados do Estado. Na Região de Governo de São Carlos, que abrange o municipio de Descalvado, foi relatada uma redução de cerrado da ordem de 93\%, ou seja, 115.000 ha no periodo de 1962 a 1992 (KRONKA, 1998).

Existem no Estado, trinta e duas Unidades de Conservação com remanescentes de cerrado. Estas representam $37,6 \%$ do total das oitenta e cinco unidades consideradas, somando $43.619,46$ ha $(4,86 \%)$ da área total das Unidades de Conservação (Tabela 2). Da área total destas unidades de cerrado, apenas $38,8 \%$ dela 
encontram-se recobertas por essa vegetação (16.944,50 ha), ou seja, apenas $1,89 \%$ do universo total das Unidades (BRITO et al., 1999).

Tabela 2 - Sintese das áreas de cerrado protegidas no Estado de São Paulo (seg. BRITO et al., 1999).

\begin{tabular}{ccc}
\hline Unidades & N $^{\mathbf{0}}$ & Área (ha) \\
\hline Parque Estadual & 4 & $4.412,75$ \\
Estação Ecológica & 7 & $13.119,42$ \\
Reserva Biológica & 1 & $24.921,65$ \\
Estação Experimental & 17 & 470,04 \\
Floresta Estadual & 3 & 695,60 \\
\hline Total & 32 & $43.619,46$ \\
\hline Porcentagem & 37,65 & 4,86 \\
\hline
\end{tabular}

\subsubsection{Caracterização ambiental como base para implementação do licenciamento dos recursos naturais}

Para SOUZA (1993), cabe à caracterização ambiental determinar as vocações e as susceptibilidades naturais que a região apresenta, permitindo que as potencialidades sejam exploradas, respeitando-se os limites da capacidade de suporte do meio ambiente. Definir a capacidade de suporte dos ambientes é considerada uma das funções mais importantes da caracterização ambiental, por possibilitar elaboração de planos de ação que estabeleçam de antemão o ritmo e a concentração de atividades compatíveis com a exploração sustentável dos recursos. $O$ autor destaca, ainda, a importância no conhecimento do meio e dos processos inerentes a este, da atuação dos centros de pesquisa particulares e estatais, fundações, secretarias, departamentos e outros, que apresentem contribuições e/ou possam atuar na fiscalização, gestão, manejo e conservação do meio ambiente.

No presente trabalho, a caracterização ambiental é a primeira etapa para estabelecer a implementação do licenciamento florestal com uma abordagem ecossistêmica. Compreende o levantamento e sistematização de dados sobre aspectos 
fisicos (clima, geologia, pedologia, etc.), biológicos (fauna e flora), paisagísticos, antrópicos (uso do solo), entre outros, que possam intervir no sistema ambiental, e como eles se inter-relacionam.

O levantamento de dados para estabelecer a caracterização ambiental pode ser realizada em diferentes escalas geográficas, ou seja, considerando somente características localizadas, por exemplo, no perímetro de uma propriedade, com perda de grande parte de informações importantes relacionadas à visão ecossistêmica, ou a partir de uma visão macro do ambiente, através de imagens de satélites e modelos matemáticos, utilizados no âmbito da Ecologia da Paisagem.

Entende-se que, na prática, se aplicados individualmente os dois extremos, pode-se incorrer, com grande chance, na análise equivocada do ambiente. Considerase que, na atividade do licenciamento de áreas florestais voltada para a conservação da biodiversidade, uma conjunção das duas abordagens constitui a forma ideal de diagnóstico. A avaliação de campo fornece uma percepção das peculiaridades da área, que são impossíveis de serem percebidas pelas imagens. Em contrapartida, a imagem fornece uma visão macro do quadro ambiental, como a dispersão, fragmentação e conectividade entre as áreas de vegetação natural, acidentes topográficos de paisagem (serras e outros), bacia hidrográfica (drenagem), entre outros fatores, que são imprescindíveis de consideração quando da tomada de decisão relativa à apropriação de um recurso natural.

Para realizar a caracterização ambiental é necessário, também, investigar os fatores de perturbação que possam estar afetando um ecossistema. Por esse motivo, incluiu-se neste tópico conceitos teóricos e exemplos práticos sobre regressão de ecossistemas e sucessão de florestas, algumas recomendações sobre a importância de uso de solo, que incorpora fatores ambientais, na limitação de uso ou manejo. Além destes, serão incluidos alguns princípios e conceitos relativos à Ecologia da Paisagem, que foi parcialmente contemplada no desenvolvimento da metodologia utilizada.

\section{Ecossistemas Florestais: regressão e sucessão}

Segundo MOORE (1997), 50 a $75 \%$ de todos os seres vivos necessitam de floresta como habitat. Isso ocorre porque as partes vivas da árvore, principalmente 
seu tronco e sua copa, criam condições específicas que não existiriam sem a sua presença. A copa das árvores proporciona milhões de oportunidades para a vida de insetos e pássaros. Sob a copa das árvores, no interior da floresta, o ambiente é protegido de geadas, nos climas frios, do calor excessivo do Sol, nos climas quentes, e do vento em todos os tipos de clima. Dessa forma, são criados milhões de novos nichos ou habitats, para que novas espécies se desenvolvam e se tornem dependentes da floresta.

A integridade desses ecossistemas supõe a manutenção de uma larga gama desses processos ecológicos, que dão lugar a interações, colocando em jogo as plantas, os animais, os microrganismos, o solo, a água e o ar. São esses processos que determinam a formação dos solos, a reciclagem dos elementos nutritivos, o estoque de carbono e a depuração das águas, preenchendo outras funções essenciais à vida. A capacidade de produção de um ecossistema é a sua aptidão de produção e manutenção da vida.

Os ecossistemas florestais em boa saúde conservam sua integridade, sua resistência e sua capacidade de produção. Graças à sua grande resistência natural, os ecossistemas saudáveis podem adaptar-se e restabelecer-se de uma perturbação ou estresse (MOORE, 1997).

As florestas são resultado de uma evolução e adaptação às perturbações que se sucederam durante milhares de anos. Toda variação importante, em intensidade ou em regime de perturbação natural, como os incêndios, as pragas e as modificações climáticas, podem ser o sinal de uma modificação no estado de saúde dos ecossistemas. Os ecossistemas florestais sofrem o efeito das intervenções humanas, tais como o corte de madeira, a urbanização, as atividades recreativas, além de outros fatores como o estresse da poluição (MOORE, 1997).

O desflorestamento é o processo de desaparecimento das florestas por efeito direto ou indireto da ação humana, e que não ocorre de uma só vez. O corte das árvores é apenas a primeira fase do desflorestamento, porém, visualmente, aquela de maior impacto, uma vez que o aspecto é desolador e parece que tudo foi destruído. No entanto, as florestas se restabelecem depois de um corte raso - por meio de regeneração natural -, da mesma forma que se fossem destruídas pelo fogo ou por qualquer forma de evento catastrófico. As florestas tiveram de se recuperar de eras 
glaciais, furacões, vulcões e avalanches. $\mathrm{O}$ desflorestamento é um processo contínuo de intervenções que evitam o ressurgimento da floresta, sendo causado, principalmente, pela agricultura, pecuária, indústria e desenvolvimento urbano. $O$ fenômeno em que a composição das plantas e de outras espécies muda ao longo do tempo é conhecido como "sucessão ecológica florestal" (MOORE,1997).

Depois de uma grande perturbação como o corte raso ou queimada intensa, as primeiras plantas que se estabelecem na sucessão secundária são as de pequeno porte, chamadas pioneiras. Estas favorecem o aparecimento de outras maiores, que, por sua vez, sombreiam e eliminam as anteriores. Terminado o ciclo de vida das espécies de crescimento rápido, podem surgir clareiras, e reaparecer as espécies pioneiras. As condições criadas pelas espécies dos estágios iniciais da sucessão podem favorecer o aparecimento de espécies de climax, que são mais exigentes quanto aos aspectos nutricionais e condições microclimáticas (MANTOVANI, 1997).

Os elementos mais importantes no processo de sucessão de vegetação natural são: o solo, fornecendo nutrientes e mantendo sementes das espécies eliminadas, funcionando como "banco de sementes", e o entorno, que tem papel relevante, pela existência ou não de ilhas de vegetação, que sirvam como fonte de propágulos, que são levados por agentes dispersores (MANTOVANI, 1997).

Com relação à incidência de luz, quando são formadas clareiras, dependendo do tamanho, estabelecem-se espécies que precisam de muita luz e que se desenvolvem rapidamente, impedindo, dessa forma, que espécies com as mesmas caracteristicas daquelas que existiam anteriormente se estabeleçam, alterando dessa forma o processo de sucessão e conseqüente recuperação da área. Por exemplo, na Serra do Mar, algumas samambaias cobrem áreas que produzem substâncias alelopáticas, impedindo a sucessão. Os cipós, que são importantes componentes na diversidade de florestas, podem, em certas circunstâncias, recobrir a copa das árvores, competindo pela luz, e até mesmo causar sua morte. Em pequenos fragmentos de vegetação, é necessária a manutenção de uma faixa tampão com espécies heliófilas, que não permitam o estabelecimento de lianas (MANTOVANI, 1997). 
A definição do estágio sucessional da vegetação arbórea nos processos de licenciamento para emissão de autorização para supressão de vegetação natural é de extrema importância, uma vez que existe legislação relacionada a este parâmetro que pode ser impeditiva, especialmente a partir do estágio médio de desenvolvimento.

\section{$>$ Os solos}

A caracterização do solo é uma das informações mais relevantes na caracterização ambiental e deveria ser considerada na prática do licenciamento florestal. Os solos podem ser considerados como o terceiro maior componente suporte da vida na biosfera (ODUM, 1993). São o produto da alteração física e química da crosta terrestre (rocha matriz) e da atividade de vários organismos, especialmente vegetais e microrganismos. Os riscos das atividades humanas sobre este componente natural variam de acordo com a suscetibilidade ambiental natural dos solos e o tipo de tecnologia empregada pela atividade (PIRES, 1995).

Dentre os riscos ambientais a que os solos estão submetidos, a erosão pode ser considerada uma das maiores ameaças. Qualquer conversão do uso do solo da vegetação natural para outro uso, se realizada sem critérios de manejo conservacionistas, tendem a acelerar a taxa de erosão, trazendo efeitos negativos à qualidade ambiental, bem como às próprias atividades produtivas. A erosão diminui a produtividade do solo devido à perda da capacidade de estoque de água disponivel, perda de nutrientes e desagregação de sua estrutura. Por outro lado, as áreas que recebem os solos perdidos são impactadas negativamente, causando assoreamento dos corpos d'água e colmatação de outros sistemas naturais e artificiais, e as conseqüências correlatas à biota nesses locais.

A diversidade dos ecossistemas da região tropical é extremamente grande, e os solos fazem parte desse complexo de recursos naturais e, portanto, também variam significativamente. Sob esse aspecto, é fundamental o reconhecimento de suas potencialidades e limitações, objetivando não somente a produtividade econômica máxima como também protegê-los contra possiveis danos ambientais (PRADO, 1998). 


\section{Ecologia da paisagem}

Atualmente, quando se fala em caracterização ambiental, não se pode dissociar o aspecto da paisagem. A Ecologia da Paisagem é a matéria que enfatiza grandes áreas e os efeitos ecológicos da modelagem espacial dos ecossistemas.

A consideração de modelos espaciais distingue a ecologia da paisagem dos estudos da ecologia tradicional, que freqüentemente assumem que os sistemas são espacialmente homogêneos.

O termo Ecologia da Paisagem foi primeiramente utilizado por TROLL (1939, citado por TURNER e GARDNER, 1991), a partir da tradição européia de geografia regional e ciência da vegetação, e já está integrado no uso e planejamento de solo e tomadas de decisão na Europa.

Especificamente, são considerados em seu escopo:

- o desenvolvimento e dinâmica da heterogeneidade espacial;

- as interações e trocas entre paisagens heterogêneas;

- $a$ influência da heterogeneidade espacial nos processos bióticos e abióticos;

- gerenciamento da heterogeneidade espacial (TURNER e GARDNER, 1991).

A paisagem pode ser observada de vários pontos de vista, e o processo ecológico na paisagem pode ser estudado em diferentes escalas temporais e espaciais (TURNER e GARDNER, 1991). Paisagem comumente refere-se a formas de terra de uma região num conjunto, ou a superficie de terra e sua associação com habitats na escala de hectares a vários quilômetros quadrados. Mais simplesmente, a paisagem pode ser considerada como uma área espacialmente heterogênea.

Três características da paisagem são especialmente utilizadas para estudos: estrutura, função e modificação. Estrutura refere-se à relação espacial entre os ecossistemas distintos, isto é, a distribuição de energia, matéria e espécies em relação a tamanho, formas, números, fisionomias e configuração dos componentes. Função refere-se às interações entre os elementos espaciais, que são o fluxo de energia, matéria e organismos pertencentes a componentes dos ecossistemas. Modificação refere-se à alteração na estrutura e na função ao longo do mosaico ecológico, ao longo do tempo (TURNER e GARDNER, 1991).

Algumas definições são importantes quando se fala da análise dos processos ecológicos considerando alterações de paisagem: 
- Escala cartográfica: o grau de redução espacial indicando o comprimento usado para representar uma unidade de medida maior; relação de distância no mapa e distância na superficie da terra representada pelo mapa, usualmente expressa em $1: 10.000$, entre outras.

- Resolução: precisão de medida: tamanho de grão, se espacial.

- Grão: o mais fino nível de resolução possível com um dado conjunto de dados; por exemplo, tamanho do "pixel" para dađos raster.

- Nível de organização de população: a localização dentro de uma hierarquia biótica (organismo, demo, população, etc.).

- Extensão: o tamanho da área de estudo ou duração de tempo sob consideração.

- Extrapolação: a inferência a partir de dados conhecidos; estimativa de um valor a partir de condições de argumento não utilizado no processo de estimativa; transferência de informações de uma escala a outra, ou de um sistema a outro na mesma escala.

- Limiar crítico: o ponto no qual existe uma abrupta modificação na qualidade, propriedade ou fenômeno.

- Escala absoluta: a distância real, direção, forma e geometria.

- Escala relativa: uma transformação de escala absoluta a uma escala que descreve a distância relativa, direção ou geometria baseada em alguma correlação funcional (por exemplo: distância relativa entre dois locais com base no esforço requerido por um organismo para mover-se entre eles; extensão geográfica da espécie).

- Mancha de habitat: o local onde a população existe.

Novas idéias na dinâmica ecológica têm surgido pelos estudos de paisagem, e conduzido a hipóteses que podem ser testadas numa diversidade de sistemas e em várias escalas. Diversos estudos indicam que a paisagem tem limites críticos, nos quais os processos ecológicos poderão apresentar modificações qualitativas relevantes. Por exemplo, o número e o comprimento dos contornos das manchas numa paisagem podem variar rapidamente próximo do limiar crítico, e esta modificação pode ter importantes implicações para a persistência das espécies. A fragmentação de habitat pode progredir com pequeno efeito na população até que a configuração crítica de conectividade seja interrompida; então, uma pequena 
alteração próximo ao limiar crítico pode ter conseqüências dramáticas para a persistência da população. Similarmente, um amplo distúrbio através de uma paisagem pode ser controlado pela freqüência da perturbação quando o habitat está abaixo do limiar crítico (TURNER e GARDNER, 1991). As hipóteses relativas à existência e efeitos de limiares críticos na configuração espacial podem agora ser testadas pela utilização de uma diversidade de paisagens, processos e escalas.

No presente estudo, foram considerados especialmente as formas e tamanho dos fragmentos de vegetação natural (manchas de habitats), como base para análise da fragmentação, cujo resultado deverá servir como subsídio para tomada de decisão nos processos de licenciamento ambiental. 


\section{ESTUDO DE CASO}

Com o intuito de aplicar os fundamentos apresentados a uma situação real, foi realizado um estudo de caso, utilizando o municipio de Descalvado, Estado de São Paulo, como unidade territorial básica.

\subsection{Metodologia}

\subsection{1. Área de estudo}

O município de Descalvado abrange área de aproximadamente 75.720 ha $\mathrm{e}$ encontra-se cerca de $242 \mathrm{Km}$ a noroeste do municipio de São Paulo. O principal acesso é feito pelas rodovias dos Bandeirantes e Anhangüera até Porto Ferreira, dai acessando a SP-215, que conduz a Descalvado.

Está situado na porção nordeste do Estado de São Paulo, entre as coordenadas aproximadas de $21^{\circ} 44^{\prime}$ e $22^{\circ} 04^{\prime}$ de latitude sul e $47^{\circ} 30^{\prime}$ e $47^{\circ} 47^{\prime}$ de longitude oeste (Figura 1). O município faz divisa com os municipios de Luís Antônio e Santa Rita do Passa Quatro, ao norte, Porto Ferreira e Pirassununga, a leste, São Carlos, a oeste, e Analândia ao sul. O último censo do IBGE, de 1991, registrou uma população de 25.734 habitantes.

\subsubsection{Levantamento e sistematização das informações para caracterização ambiental.}

Para a caracterização ambiental do município, foram levantados os mapas e respectivas escalas disponíveis, contendo informações relativas aos aspectos físicos e biológicos relevantes para uma avaliação ambiental abrangente, enfatizando a avaliação da paisagem:

- Topografia, hidrografia e infra-estrutura: Carta do Brasil, escala 1:50.000, folhas Descalvado, Luiz Antônio, Corumbataí, Porto Pulador e São Carlos, do IBGE, 1971.

- Pedologia: Levantamento pedológico semidetalhado do Estado de São Paulo, escala 1:100.000, Folhas São Carlos e Descalvado, do IAC (Instituto Agronômico de Campinas), 1981 e 1982, respectivamente, digitalizadas com a discriminação das grandes classes. 


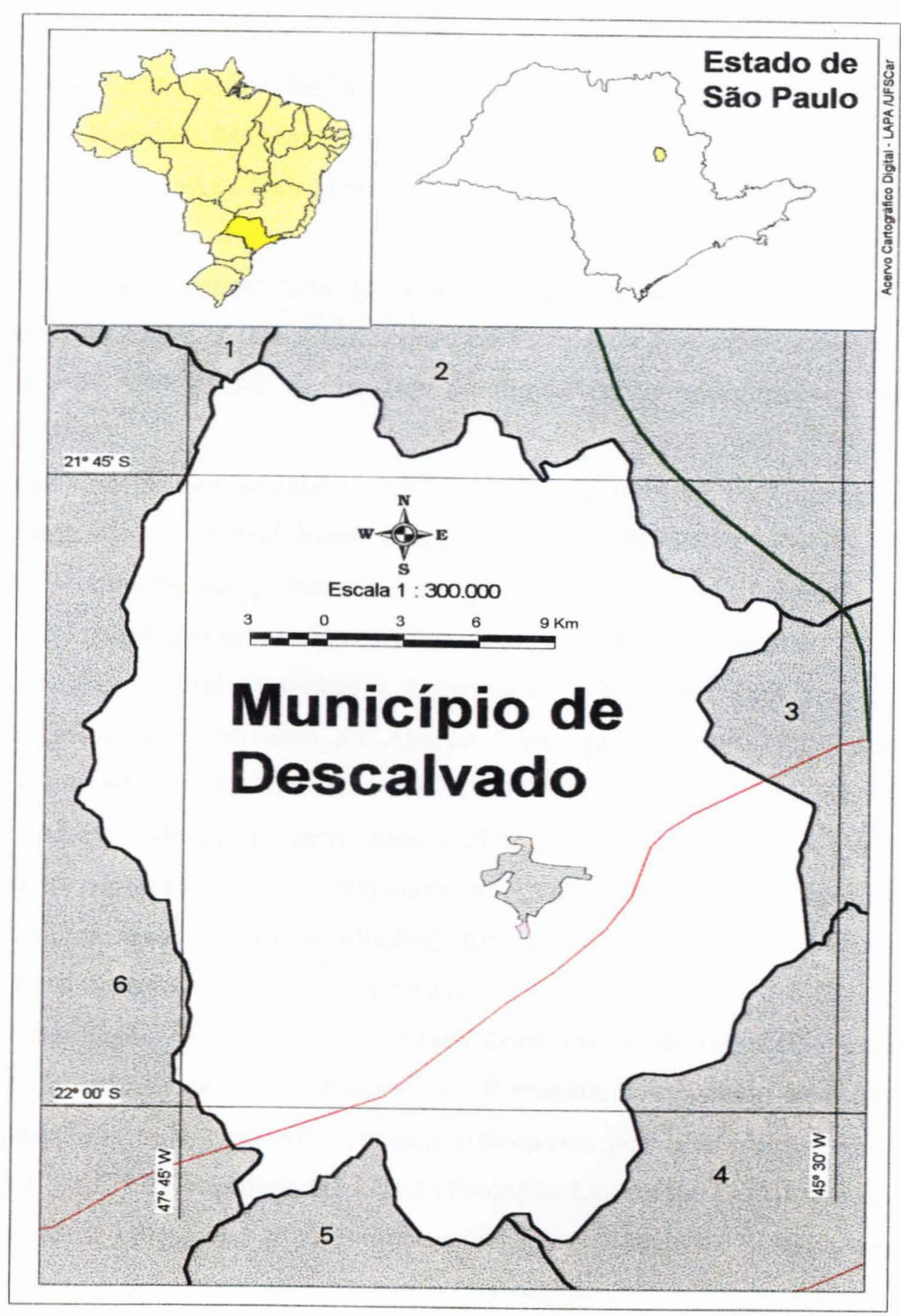

Figura 1 - Localização do município de Descalvado, SP; (1) município de Luís Antônio; (2) município de Santa Rita do Passa Quatro; (3) municipio de Porto Ferreira; (4) município de Pirassununga; (5) município de Analândia; (6) município de São Carlos (UFSCAR/LAPA, 2000). 
- Geologia: mapa de Formação Geológica de superficie, escala 1:50.000, folhas Descalvado, Luiz Antônio e Corumbataí, do Instituto Geológico, 1984.

- Vegetação Natural: Mapeamento de vegetação natural do Estado de São Paulo, escala 1:50.000, folhas Descalvado, Luiz Antônio, Corumbataí e Ibaté, do DEPRN, 1989.

A cartografia supracitada foi transformada numa base de dados digital no Departamento de Hidráulica e Saneamento da Escola de Engenharia de São Carlos da Universidade de São Paulo; os detalhes da digitalização encontram-se referidos em RANIERI (2000).

O trabalho de campo relativo à análise dos fragmentos de vegetação nativa foi realizado segundo a metodologia empregada por PIRES e PIRES (no prelo). Basicamente, consiste no processamento de uma imagem TM Landsat, 1997, em formato digital, onde são separados os fragmentos de vegetação natural.

A imagem digital contendo a informação sobre os fragmentos florestais da Cidade de Descalvado pertence ao Acervo Cartográfico Digital do Laboratório de Análise e Planejamento Ambiental - LAPA da Universidade Federal de São Carlos UFSCAR. Através dessa imagem, foram obtidos dados relativos à quantidade dos fragmentos de vegetação natural existente no município e sua distribuição por área (hectares). Com base nestes resultados, foi discutida sua importância ambiental, sobretudo com relação ao tamanho e à forma.

A verificação de campo foi realizada com auxilio de um GPS modelo Garmin $12 \mathrm{XL}$, após a escolha de alguns fragmentos florestais, localizando-os a partir de uma carta-imagem (analógica) georreferenciada sobreposta por uma transparência contendo uma grade ("grid") de coordenadas UTM (Projeção Universal Transversa de Mercator) relativas ao local (Figuras 2 e 3), fixadas sobre uma prancheta. Sobre a transparência, foi anotada uma referência numérica para o fragmento.

Em folha à parte, foram anotados: a posição do fragmento em UTM, obtida com o GPS, as suas características fisionômicas genéricas e seu estado de conservação (bom ou mau).

Foram anotadas as seguintes características gerais:

- Cerrado - para formações ditas savânicas, denominadas: campo sujo, campo 
Municipio de DESCALVADO - Carta $p /$ Verdade Terrestre

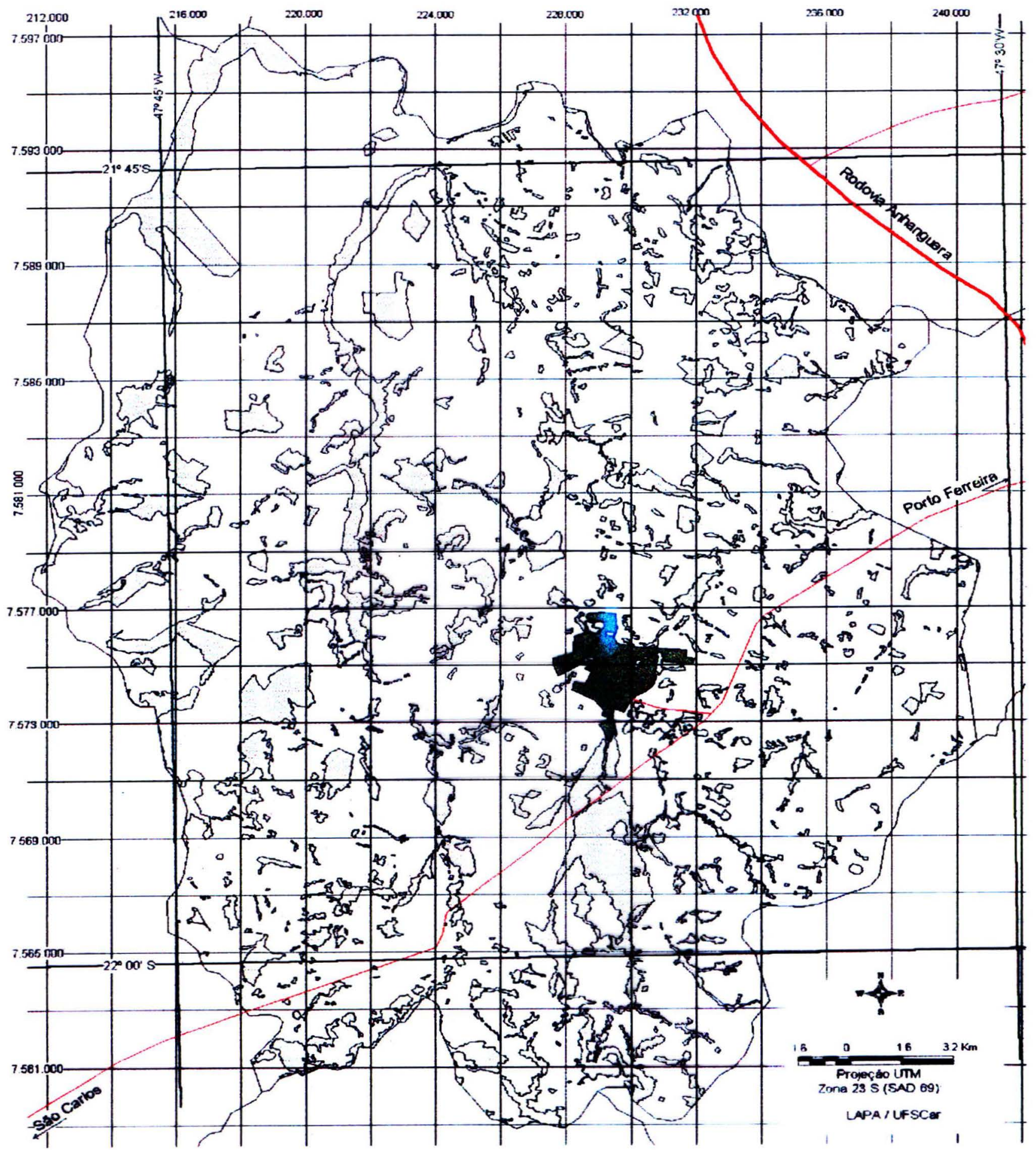

Figura 2 - Transparência com a grade ("grid") de coordenadas UTM do municipio de Descalvado (SP), utilizada em campo (UFSCAR/LAPA, 2000). 


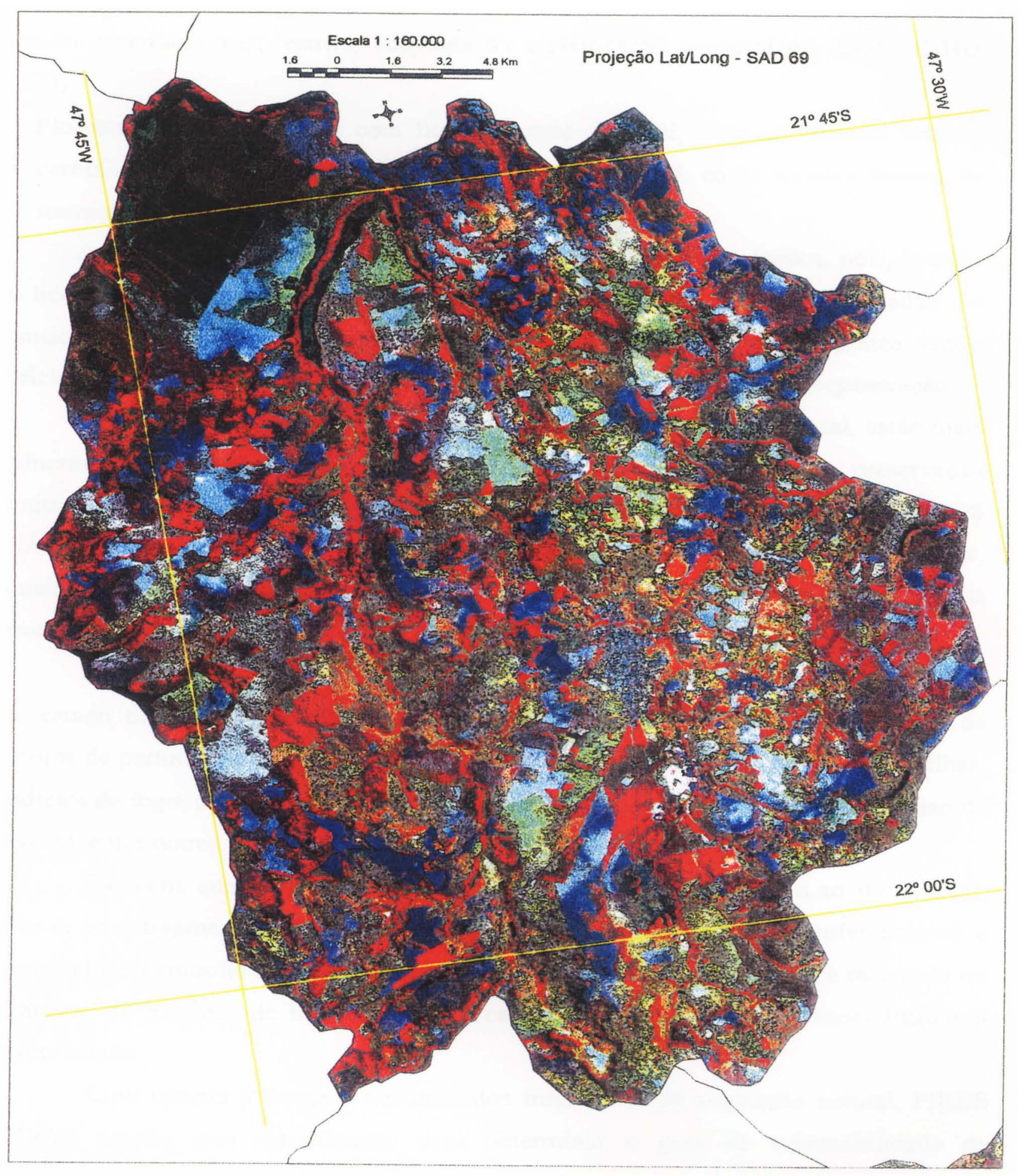

Figura 3 - Imagem georreferenciada TM Landsat 1997 do município de Descalvado (SP), utilizada para identificação dos fragmentos de vegetação natural (UFSCAR /LAPA, 2000) . 
cerrado e cerrado senso estrito, adaptada da classificação proposta por COUTINHO (1978).

- Floresta - para formações com fitofisionomia florestal, onde se inserem tanto o cerradão, as florestas estacionais semi-deciduais - FLES, como aquelas formas de transição de cerradão para FLES.

A diferenciação e simplificação devem-se ao fato de ordem prática, pois, quando do licenciamento para corte raso, as formaçōes florestais, por exemplo, o cerradão em transição para FLES, encontram amparo no Decreto n $750 / 93$ de Mata Atlântica, sendo suficientemente protegidos do corte raso a partir de seu estágio médio de regeneração.

Já as formações de cerrado, apesar da grande importância ambiental, estão mais vulneráveis, sob o aspecto de proteção legal, praticamente ficando a sua preservação limitada aos estritos $20 \%$ preconizados no Código Florestal. O Decreto $n{ }^{\circ} 42.838 / 98$ (SĀO PAULO, 1998), que declara as espécies silvestres ameaçadas de extinçāo é, atualmente, conforme já mencionado, o instrumento legal que vem auxiliando na proteção dessas áreas.

Com relação à qualificação dos fragmentos florestais vistoriados sob o aspecto do estado de conservação (bom ou mau), foi observada, sobretudo, a ocorrência de fatores de perturbação na sua borda ou em seu interior, tais como a presença de trilhas, indícios de fogo, clareiras, pastoreio, presença de vegetação invasora (capim, excesso de lianas), entre outros.

Também, quando possivel, foi anotada sua situação com relação ao status legal, isto é, se o fragmento era ou não averbado como Reserva Legal. Tal referência só é possivel pela consulta ao órgão ambiental (DEPRN), através de consulta à matricula no Cartório de Registro de Imóveis, ou em campo, por indagação às pessoas ligadas à propriedade.

Com relação à forma e tamanho dos fragmentos de vegetação natural, PIRES (1995) propôs uma classificação para determinar o grau de vulnerabilidade de fragmentos florestais, utilizando como ponderações o indice de borda (InB) e a razão interior/borda (L/B). Esta classificação pode auxiliar sobremaneira na identificação de áreas prioritárias para medidas de proteção e projetos de manejo. $O$ autor ressalta, entretanto, que nunca se deve perder de vista o nivel da escala de trabalho, tanto espacial quanto temporal, ao se realizar extrapolaçōes de conclusões e inferências, pois 
conclusões obtidas numa escala espacial ou temporal podem não ser verdadeiras em outra

Para uma consideração qualitativa de vulnerabilidade, relacionada à forma e tamanho dos fragmentos, adaptada de PIRES (1995), para fins práticos considerou-se os seguintes critérios para os fragmentos de vegetação natural na área de estudo (Figura 4):

1. Tamanho do Fragmento:

- Pequeno a médio $=$ até 100 ha

- Grande: acima de 100 ha

2. Forma do Fragmento:

- Arredondado: Ilha $(\operatorname{InB}=1)$

- Alongado: Corredor (InB $>>1)$

\begin{tabular}{|l|c|c|}
\hline $\begin{array}{c}\text { InB } \\
\text { (Tamanho) }\end{array}$ & $\begin{array}{c}\text { Arredondado } \\
(1)\end{array}$ & $\begin{array}{c}\text { Alongado } \\
(>>1) \\
\text { Ilha }\end{array}$ \\
\hline PEQUENO $(0)$ & Alta Vulnerabilidade & Alta Vulnerabilidade \\
\hline GRANDE $(>>1)$ & Baixa Vulnerabilidade & $\begin{array}{c}\text { Alta ou Média } \\
\text { Vulnerabilidade }\end{array}$ \\
\hline
\end{tabular}

Figura 4 - Matriz de vulnerabilidade ecológica simplificada para avaliação qualitativa dos fragmentos de vegetação natural (adaptada de PIRES, 1995).

Os valores referentes ao tamanho do fragmento foram definidos com base no perfil de distribuição dos fragmentos registrados na área de estudo.

Por essa interpolação de qualidades, pode-se inferir que os fragmentos pequenos, independentemente de sua forma, sempre são mais vulneráveis às perturbações do entorno. 
Algumas características e qualidades edáficas e ambientais que indicam o potencial de uso do solo também são fundamentais na caracterização ambiental, propiciando o reconhecimento das potencialidades e limitações de seu uso e tipo de ocupação, como, por exemplo, avaliação de susceptibilidade à erosão.

Os valores referentes ao tamanho do fragmento foram definidos com base no perfil de distribuição dos fragmentos registrados na área de estudo.

Por essa interpolação de qualidades, pode-se inferir que os fragmentos pequenos, independentemente de sua forma, sempre são mais vulneráveis às perturbações do entorno.

\subsubsection{Areas averbadas como Reservas Legais}

Foram levantadas, junto ao DEPRN - Equipe Técnica de São Carlos, as informações sobre todos os fragmentos florestais averbados à perpetuidade na matrícula do Cartório de Registro de Imóveis do municipio de Descalvado, como Reservas Legais.

\subsubsection{Legislação pertinente e procedimentos no Ministério Público}

Os textos legais foram obtidos a partir de consultas a livros jurídicos sobre Direito Ambiental, nos próprios Códigos, em sites especializados (via Internet) e no Diário Oficial. As discussōes foram feitas com base no entendimento dos juristas referidos na bibliografia e discussões pessoais com os promotores de Meio Ambiente do Ministério Público das Comarcas de São Carlos e de Descalvado. Os dados relacionados aos procedimentos na esfera da Promotoria de Descalvado iniciados por infrações ambientais foram fornecidos por este (MINISTÉRIO PÚBLICO DO ESTADO DE SÃO PAULO, 2000). 


\subsection{Resultados e Discussão}

\subsubsection{Caracterização da Área de Estudo.}

\section{Aspectos Físicos}

O município de Descalvado está inserido na província geomorfológica das Cuestas Basálticas, que "trata-se de relevo dissimétrico, constituído por um lado de perfil côncavo em declive íngreme, denominado fronte, e do outro de perfil suavemente inclinado, denominado reverso" (SÃO PAULO, 1995).

Verifica-se, regionalmente, uma diversidade de paisagens topográficas, permitindo distinguir quatro formas distintas de relevos (T. ALVES ENGENHARIA, 1990):

- Relevos de morros com encostas suavizadas, com declividades inferiores a $15 \%$ e amplitudes locais de 100 a 300 metros, predominando morros amplos. Constituem interflúvios arredondados com área superior a $15 \mathrm{Km}^{2}$, topos arredondados, vertentes com perfis retilíneos e convexos, baixa densidade de drenagem, padrão dendrítico, vales abertos e com planicies inferiores restritas, sujeitas a boçorocas.

- Relevos de transição com encostas não escarpadas, com declividades médias de 15 a $30 \%$ e amplitudes maiores que 100 metros. Ocorrência de desfiladeiros locais caracterizados por vertentes com perfis retilineos a convexos e trechos escarpados. Drenagem de média densidade e vales fechados com fundo chato.

- Relevos residuais suportados por rochas sedimentares, constituídos por mesas sedimentares com morros tubulares de bordas escarpadas, formando mesas isoladas ou conjunto de mesas, topos achatados, vertentes com perfis retilíneos, freqüentemente escarpadas e com exposições locais de rochas (morros testemunhos de arenitos Botucatu silicificados).

- Áreas com relevo de agradação, constituídos de planícies aluviais com terrenos baixos e razoavelmente planos, junto às margens dos córregos e do Rio MogiGuaçu, sujeitas a inundações periódicas (Figura 5). 

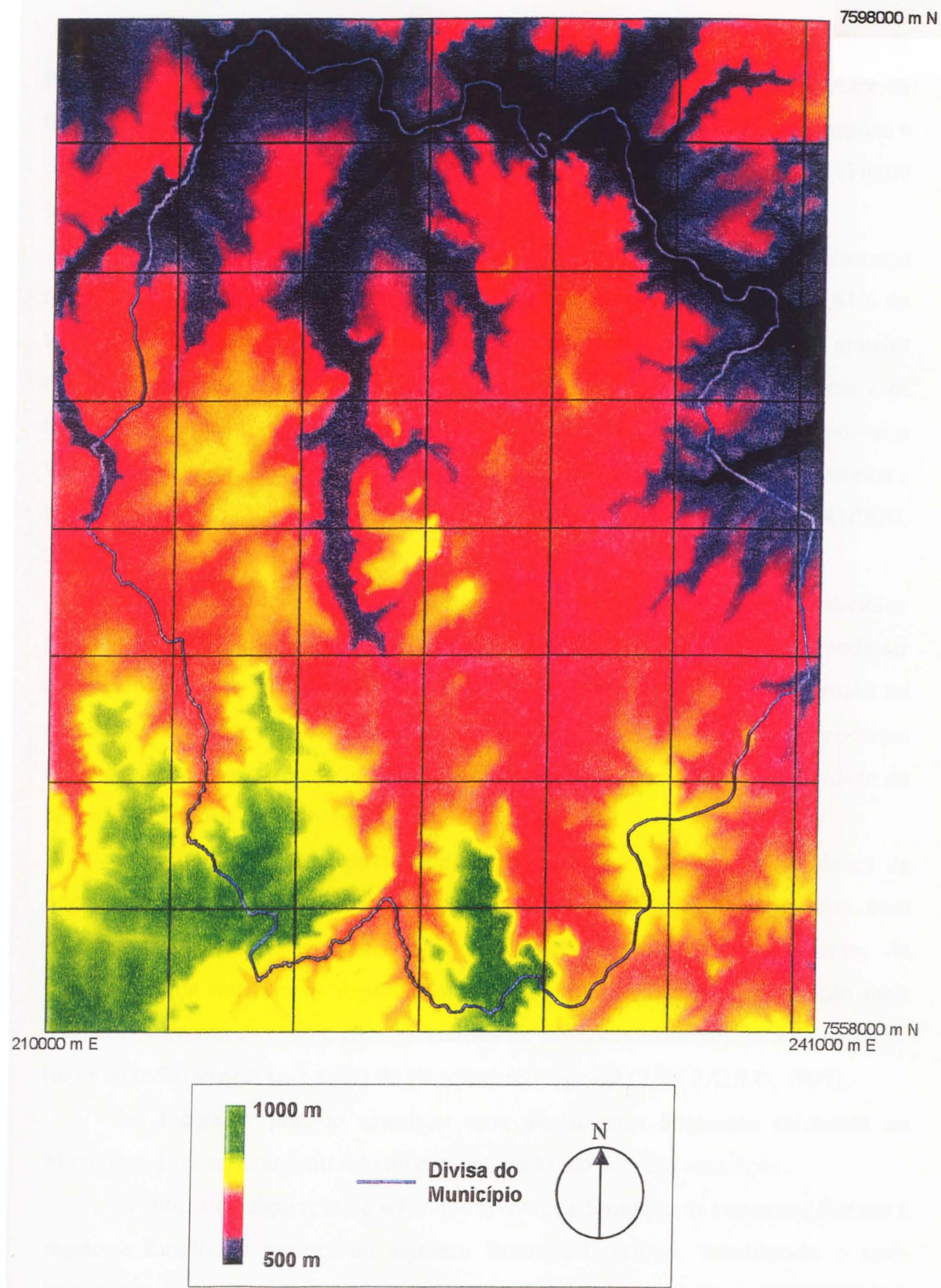

Figura 5 - Modelo digital de elevação do município de Descalvado (SP) (RANIERI, 2000). 
A formação geológica de superficie predominante é a Formação Santa Rita do Passa Quatro, com 52,37\% da área de estudo. Em menores percentuais aparecem as formações intrusivas básicas $(15,75)$ e outras formações: Serra Geral, areias, argilas e cascalho quaternário, Pirassununga, Botucatu, Pirambóia, Itaqueri e Corumbataí (Figura 6) (RANIERI, 2000).

Os solos do Município de Descalvado, formados a partir dos substratos mencionados, apresentam predominância de areias quartzosas profundas em $33,81 \%$ do território, decorrentes da decomposição da Formação Santa Rita, dominando grandes extensões contínuas. Com significativa expressão aparecem os latossolos roxos e os latossolos vermelhos-amarelos. Além destes, existe a ocorrência de latossolos vermelho-escuros, solos litólicos, solos hidromórficos, podzólicos vermelho-amarelos e terra roxa estruturada (Figura 7) (OLIVEIRA et al., 1982; PRADO, 1997, RANIERI, 2000).

A predominância dos solos arenosos, ácidos e pobres em fertilidade, condicionaos a uma grande fragilidade ambiental, que é formação de erosões. Conforme pode ser observado na Figura 8, que apresenta o mapa sintese de susceptibilidade à erosão no município, cerca de $40,8 \%$ da área apresenta susceptibilidade elevada a processos erosivos, que considera como fatores de risco o tipo de solo associado à declividade do terreno (RANIERI, 2000).

Quanto maior a susceptibilidade à erosão, maiores são as possibilidades de degradação dos recursos hídricos, resultado de desequilibrios pronunciados com aumento das taxas de escoamento superficial e diminuição dos coeficientes de infiltração, que resultam na diminuição da recarga dos aqüiferos, na produção mais freqüente e intensa de cheias, etc.. As análises de susceptibilidade constituem, portanto, importante ferramenta para ações de planejamento regional (SÃO PAULO, 1995).

$\mathrm{Na}$ Figura 9, pode-se visualizar uma das maiores boçorocas existentes no Municipio, já com manejo do solo do entorno, realizado para sua contenção.

A mesma configuração de solos que favorece a formação de boçorocas fornece à região a função de recarga do aqüífero Botucatu-Pirambóia, considerado o mais importante da América do Sul (OLIVEIRA, 1995; SÃO PAULO, 1995; PREFEITURA MUNICIPAL DE DESCALVADO, 1999). 


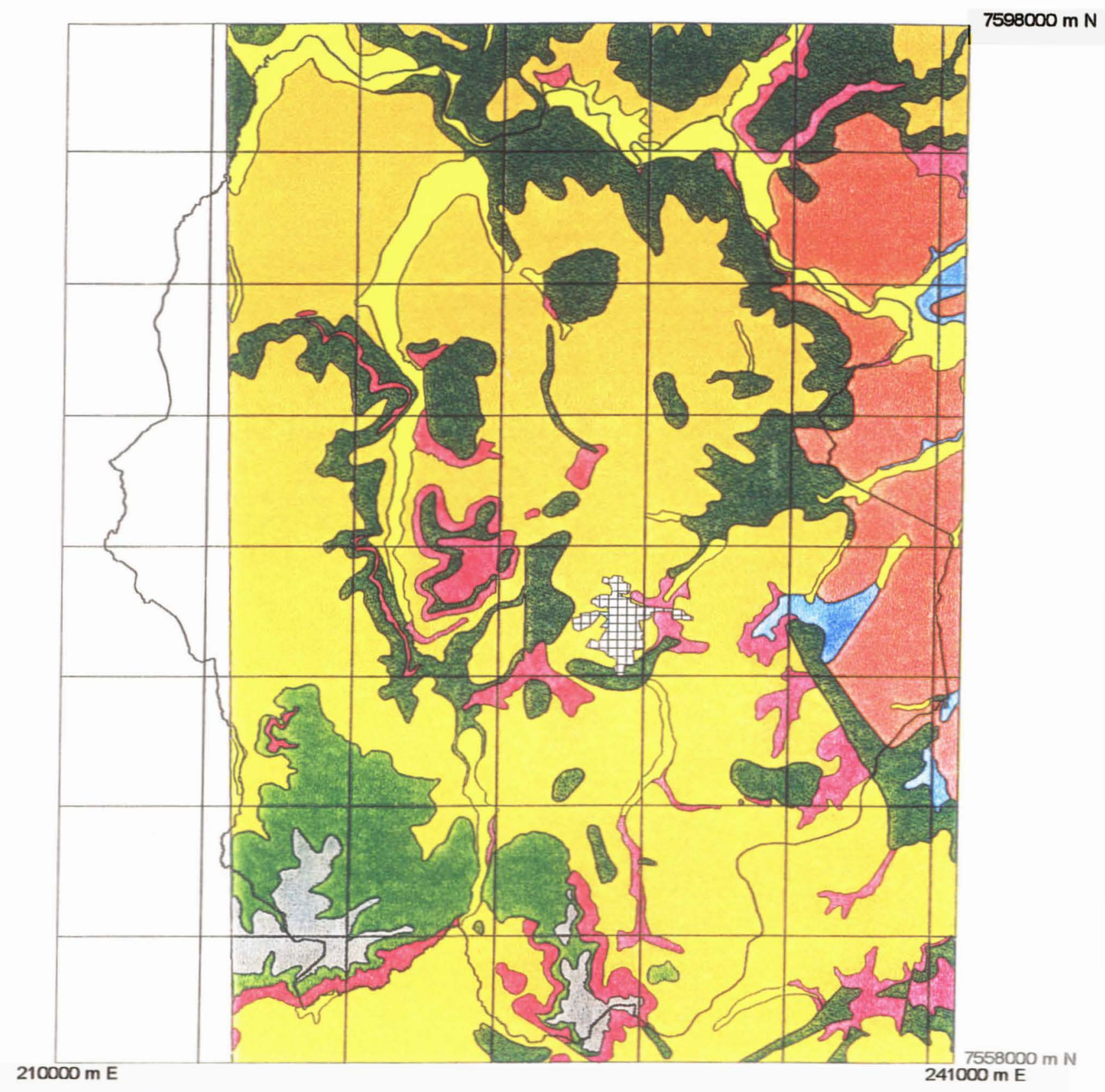

\begin{tabular}{|c|c|c|c|}
\hline$\square$ & Areias, Argilas e Cascalhos - 5.33\% & $\square$ & F. Botucatu - 3.98\% \\
\hline$\square$ & F. Santa Rita do Passa Quatro - 52.37\% & $\square$ & F. Pirambóia - $2.15 \%$ \\
\hline$\square$ & F. Pirassununga $-4.32 \%$ & $\square$ & F. Corumbataí - $0.66 \%$ \\
\hline$\square$ & F. Itaqueri - 1.74\% & $\square$ & Ärea não considerada \\
\hline 묘 & F. Serra Geral - 7.57\% & 田 & Área urbanizada \\
\hline $\mathrm{E}$ & Intrusivas Básicas - 15.75\% & 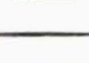 & Divisa do Município \\
\hline
\end{tabular}

Figura 6 - Formação Geológica do município de Descalvado (SP), com valores percentuais por tipo de formação (RANIERI, 2000). 

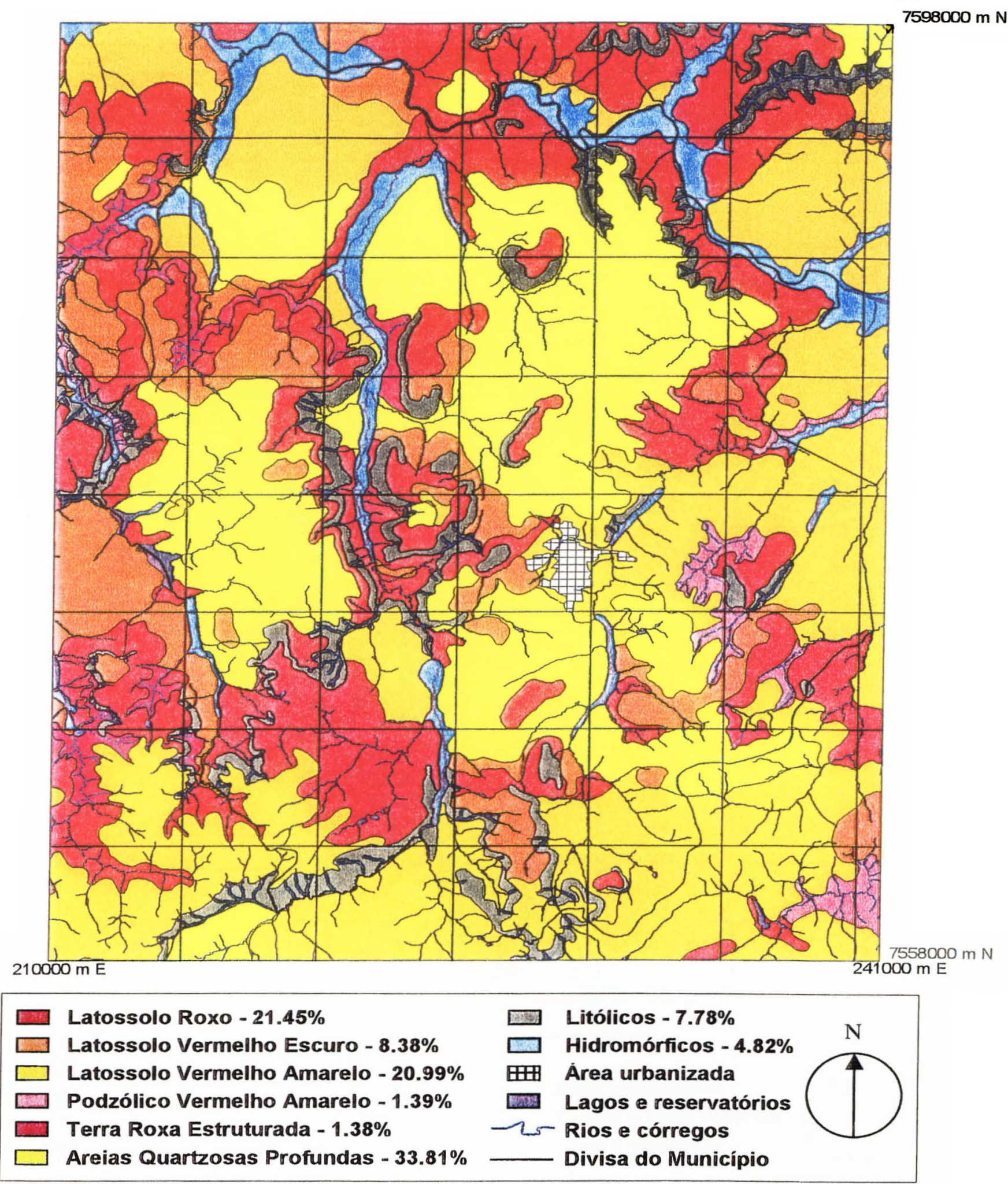

Figura 7 - Pedologia do município de Descalvado (SP), com a classificação das grandes classes e valores percentuais por classe de solo (RIZZINI, 2000). 

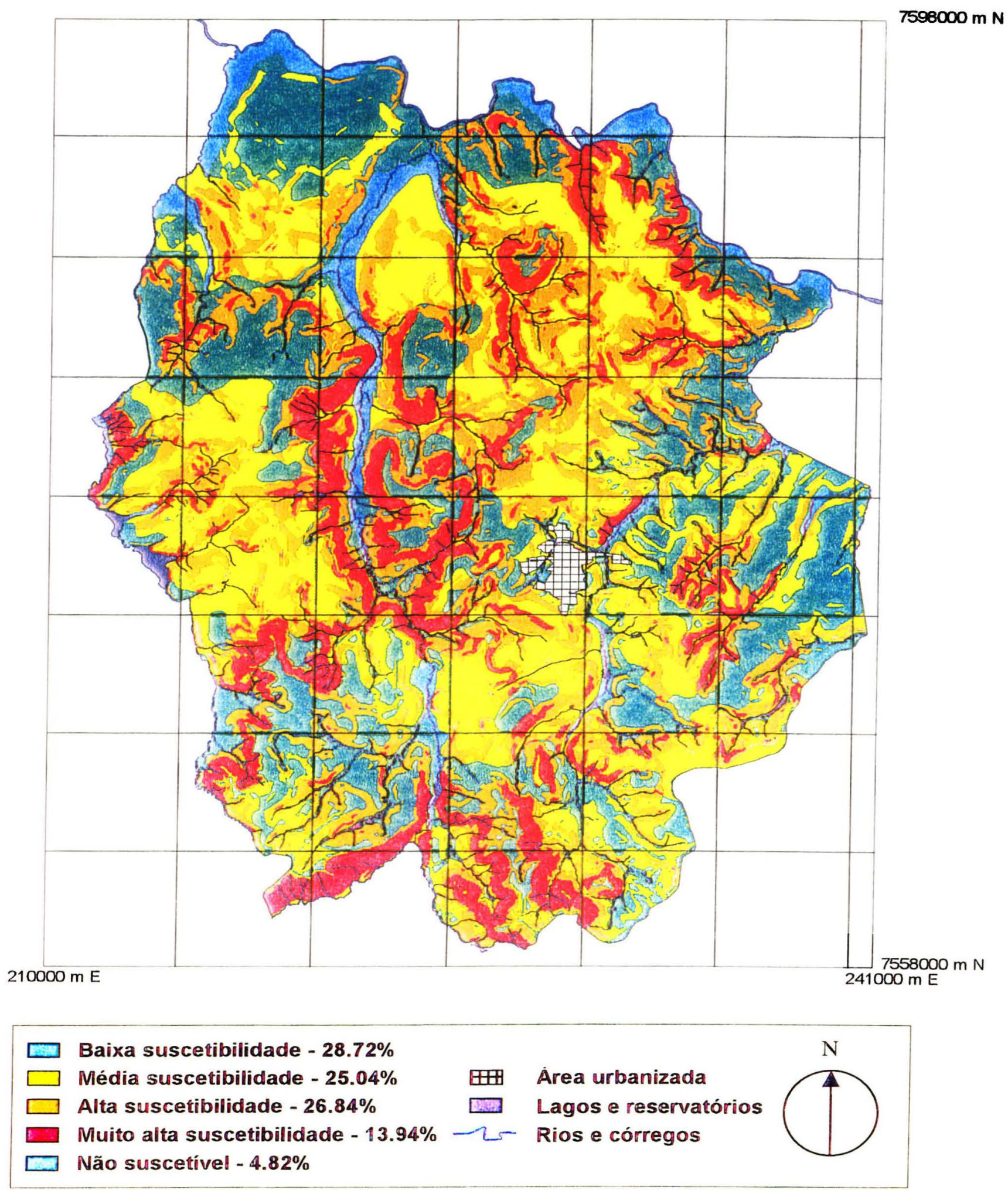

Figura 8 - Mapa síntese de susceptibilidade à erosão do município de Descalvado (SP), com a classificação e valores percentuais por categoria em relação à área (RANIERI, 2000). 


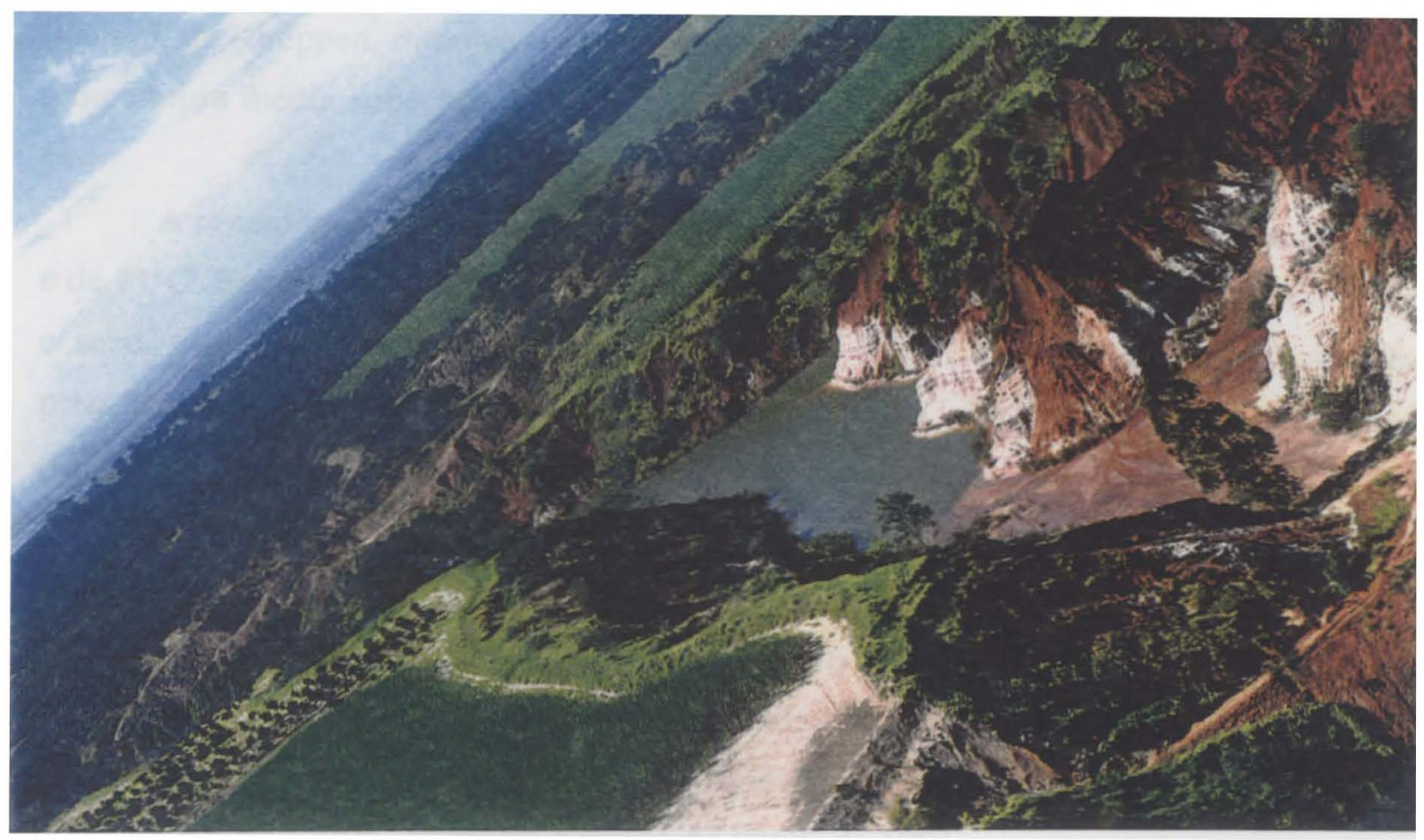

Figura 9 - Vista da boçoroca de São Clemente no municipio de Descalvado (SP) (DEPRN/ET São Carlos, 1999).

Com relação à hidrografia, o território é dividido entre duas microbacias hidrográficas principais - do Ribeirão do Pântano e do Rio Bonito - encaixadas em fundos de vale, cercados inicialmente por relevo ingreme, ao sul, passando por terras onduladas na região central até atingir, ao norte, parte da planície de inundação da média do Rio Mogi-Guaçu. Mais de 50 córregos se distribuem ao longo dessas microbacias (Figura 10). A microbacia do Pântano e as cabeceiras do Rio Bonito estão protegidas pela Área de Proteção Ambiental - APA de Descalvado (PREFEITURA MUNICIPAL DE DESCALVADO, 1999).

Destaca-se que o Rio Mogi-Guaçu delimita a divisa administrativa dos municípios de Descalvado e dos municípios de Luiz Antônio e Santa Rita do Passa Quatro. As várzeas do Rio Mogi-Guaçu e do Ribeirão do Pântano são consideradas de relevância ambiental no contexto da Bacia Hidrográfica do Mogi, Pardo e Médio 
Grande (SÃO PAULO, 1995).

Com relação ao clima, está sob influência do clima quente com inverno seco (Cwag), de Koeppen, onde se registra, para o mês mais seco, chuvas totais de $30 \mathrm{~mm}$, e temperatura média superior a $22^{\circ} \mathrm{C}$ no mês mais quente, e acima de $18^{\circ} \mathrm{C}$ no mês mais frio.

A precipitação anual média é de 1625,7 mm (1977-1994), e a temperatura média é de $21^{\circ} \mathrm{C}$. Existem duas estações bem definidas, verão quente e úmido e inverno quente e seco. O relevo influencia a ocorrência de um clima local no município, devido à presença das Cuestas, registrando próximo a esta área o aumento de chuvas (OLIVEIRA, 1995).

\section{Aspectos Sócio-Econômicos}

Quanto aos aspectos de uso e ocupação do solo, verifica-se que o município de Descalvado tem uma população de aproximadamente 26.000 habitantes, com grau de urbanização de $78,01 \%$, e apresentou, no período de 1980 a 1991 uma taxa anual de crescimento de 2,76\%, segundo o censo do IBGE de 1991.

Segundo levantamento realizado pela Secretaria de Agricultura e Abastecimento do Estado de São Paulo - Projeto LUPA, realizado nos anos de 1995/1996 (SAA, 1999), o município apresentava o seguinte perfil de distribuição, uso e ocupação de solos agrícolas:

- O solo rural estava dividido em 781 propriedades, perfazendo uma área total de $69.966,50$ ha, ou seja, $92,40 \%$ da área total do município.

- As áreas das propriedades rurais encontravam distribuidas conforme dados apresentados na Tabela 3.

- Da análise da Tabela 3, verifica-se que há um predominio de pequenas e médias propriedades com até 100 ha $(80 \%)$ que, entretanto, somam apenas $26 \%$ dos solos agricolas. Aproximadamente $74 \%$ da área rural do municipio encontra-se parcelado em somente $20 \%$ das propriedades (157 unidades acima de $100 \mathrm{ha}$ ), consideradas grandes para o perfil da distribuição. 

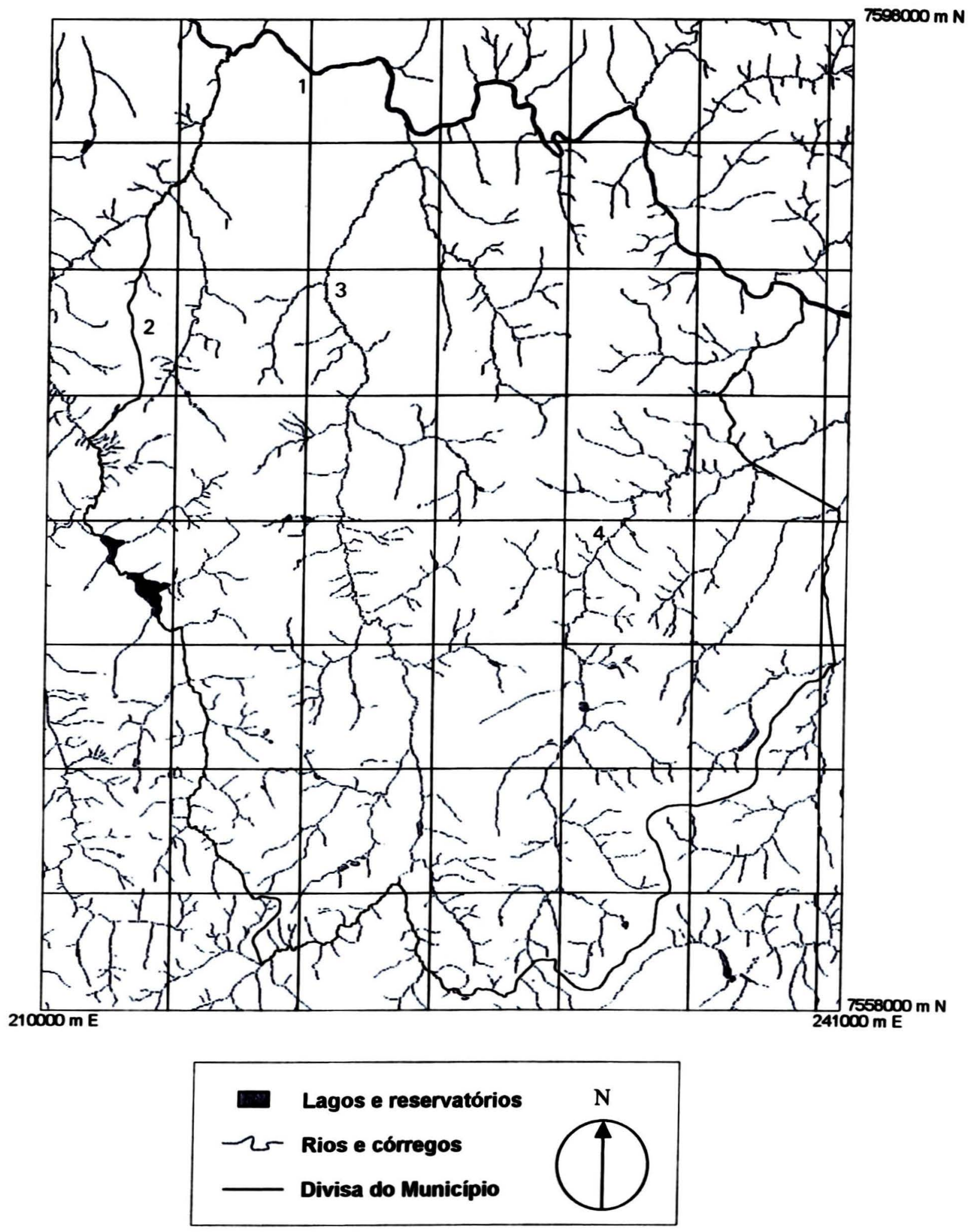

Figura 10 - Hidrografia do município de Descalvado, SP (RANIERI, 2000)

(1) Rio Mogi Guaçu; (2) Ribeirão do Quilombo; (3) Rio do Pântano; (4) Ribeirão Bonito 
- Com relação aos dados relativos à agricultura, os mesmos indicavam que, dos $69.966,50$ ha, $11.245,60$ ha $(16,07 \%)$ estavam ocupados por culturas perenes, sendo que a laranja apresentava a maior ocupação dessas áreas (10.424,00 ha); as culturas semi-perenes ocupavam uma área de $18.794,40$ ha $(26,86 \%)$ com a cultura de canade-açúcar prevalecendo em praticamente a totalidade da área $(18.700,30 \mathrm{ha})$; as culturas anuais apresentavam-se em $5.865,40$ ha $(8,38 \%)$.

Tabela 3 - Distribuição do número de propriedades rurais por área no município de Descalvado (SP) (modificado de Projeto LUPA, 1995/1996 - SAA, 1999)

\begin{tabular}{lcccc}
\hline Tamanho (ha) & $\begin{array}{c}\text { Número de } \\
\text { unidades }\end{array}$ & $\begin{array}{c}\text { \% de } \\
\text { unidades }\end{array}$ & Área (ha) & \% de área \\
\hline 0,1 a 5,0 & 79 & 10,11 & 261,80 & 0,37 \\
5,0 a 20 & 219 & 28,04 & $2.721,90$ & 3,89 \\
20 a 50 & 208 & 26,63 & $6.737,30$ & 9,62 \\
50 a 100 & 118 & 15,10 & $8.401,60$ & 12,00 \\
100 a 500 & 134 & 17,15 & $28.749,00$ & 41,08 \\
Acima de 500 & 23 & 2,94 & $23.094,90$ & 33,00 \\
\hline Totais & 781 & 100 & $69.966,50$ & 100 \\
\hline
\end{tabular}

- As pastagens apareceram com um total de $19.773,40$ ha $(28,26 \%)$, apresentando a pecuária como principal atividade desenvolvida.

- Os reflorestamentos apresentaram 1.804,20 ha, com 2,5\% de cobertura, sendo quase a totalidade com eucalipto $(1.767,20 \mathrm{ha})$.

- O levantamento indicava, ainda, que a cobertura de vegetação natural era de $8.373,00$ ha, ou seja, $11,9 \%$ da área rural ou 11,05 da área total (segundo informações fornecidas pelos próprios proprietários rurais).

A avicultura, segundo OLIVEIRA (1995), é uma das atividades de maior destaque, tendo sido o município considerado como a "capital do frango de corte". A atividade encontra-se organizada em sistema de cooperativa ou de integração, com emprego de alta tecnologia, criação por confinamento com alta produtividade e grandes investimentos. Entretanto, este setor vem enfrentando sérias dificuldades econômicas. 
No setor secundário, destacam-se, entre as grandes empresas, a Mineração Jundú, a Mineração Descalvado, a Usina de Açúcar e Álcool Ipiranga, além de fábricas de ração animal e implementos agrícolas, entre outras.

O setor terciário apresenta o predominio das micro e pequenas empresas de administração familiar, com significativa participação na economia local (OLIVEIRA, 1995). Também foi inaugurado, em 1999, um "campus" universitário, com vários cursos de graduação.

\section{Aspectos Biológicos}

Com relação aos aspectos de fauna e flora, o município de Descalvado, sob o clima tropical, com duas estações distintas e pertencente à província geomorfológica das Cuestas Basálticas, possui uma vegetação que representa uma zona de transição entre a savana (cerrado) e a floresta mesófila estacional semi-decídua, sendo que a floresta mesófila aparece amplamente disseminada em áreas de cerrado, em forma de manchas, e onde a distribuição das duas formações vegetais está associada às condições edáficas (RIZZINI,1979, citado por OLIVEIRA, 1995).

As formações de vegetação nativa identificadas em campo foram: cerrado, em todas as suas fisionomias; floresta estacional semi-decidual, matas de galeria e campos de várzea.

A floresta mesófila caracteriza-se por uma vegetação de porte médio a alto, com dossel fechado, sub-bosque bastante denso e pobre quanto ao estrato herbáceo, presença de lianas e epifitas. Em termos de composição florística, apresenta similaridade com as florestas úmidas do litoral do Estado de São Paulo, no entanto, com estrutura menos complexa. Possui espécies em comum com o cerrado, sendo uma forma de transição em composição de espécies entre a floresta sempre verde litorânea e o cerradão. Sujeita a regimes estacionais, apresenta adaptações à deficiência hidrica e caráter semidecíduo (EITEN, 1970).

O cerrado é um complexo de formações vegetais que apresenta fisionomia e composição florística variáveis, que vão desde campo limpo (formação campestre) até cerradão (formação florestal), representando em suas formações savânicas intermediárias (campo sujo, campo cerrado e cerrado senso estrito) verdadeiros ecótonos de vegetação entre aquelas duas formações. As formas savânicas podem 
apresentar a mais ampla gama de características fisionômicas e estruturais, dependendo das condições ecológicas em cada ecossistema de cerrado se aproximarem ora mais do ótimo campestre, ora mais do ótimo florestal. Várias dessas condições ecológicas podem interferir na expressão das características do cerrado, tais como condições físicas ou quimicas do solo, geomorfologia, topografia, freqüência de queimadas, pastoreio, etc. (COUTINHO, 1978).

Os cerradões, cerrados e campos ocupam formas topográficas planas e maciças, nos interflúvios dos chapadões, além de solos pobres, os quais descem até a base das vertentes, onde surgem os solos aluvionares dos vales e se implantam as florestas ciliares (AB'SABER, 1963 citado por KRONKA, 1998).

Às margens dos rios aparecem formações características denominadas, no domínio de cerrado, como matas de galeria (matas ciliares). Nos vales fluviais mais encaixados, formados por vertentes íngremes, a floresta assemelha-se bastante à mata mesófila semi-decidual, enquanto que, em vales mais amplos, apresenta o predomínio de vegetação arbustiva (OLIVEIRA, 1995).

Existem também, na área de estudo, os campos de várzea, que apresentam estruturas variáveis, distinguindo-se dos demais campos por permanecerem inundados durante algum tempo, por estarem localizados nas baixadas que margeiam os rios. Além da várzea do Rio Mogi-Guaçu, existe, no município, a extensa várzea do Ribeirão do Pântano, com 278 ha (Figura 11) (SÃo PAULO, 1995).

As várzeas são conhecidas como depósitos aluvionais e baixadas aluvionais, na linguagem geomorfológica, o leito maior dos rios. Devido às suas características, como solo saturado de água periodicamente, vegetação tolerante à inundação e adaptada à seca e fauna típica, são considerados ecótonos ciliares, ou seja, áreas de transição entre os ecossistemas aquáticos e terrestres. Quanto às suas funções, são refúgio de fauna silvestre, local de reprodução de peixes, de controle de cargas difusas e dos diversos contaminantes que ocorrem no corpo d'água. O estudo e definição de manejo das várzeas é fundamental, tanto do ponto de vista sócio-econômico como ecológico. Descalvado está localizado no trecho médio do Rio Mogi-Guaçu, na porção da planicie meândrica de inundação, onde são comuns as lagoas marginais (SÃO PAULO, 1995).

Segundo BURNETT el al. (citado em PIRES, 1999), a diversidade geomorfológica influencia a diversidade de espécies decorrente da variedade de 
habitats. Analisando a elevada diversidade geomorfológica encontrada na área de estudo, que apresenta duas microbacias hidrográficas principais - do Rio do Pântano e do Rio Bonito -, verifica-se que a mesma condiciona uma grande diversidade de habitats que, consequentemente, está relacionada a uma elevada biodiversidade na área de estudo.

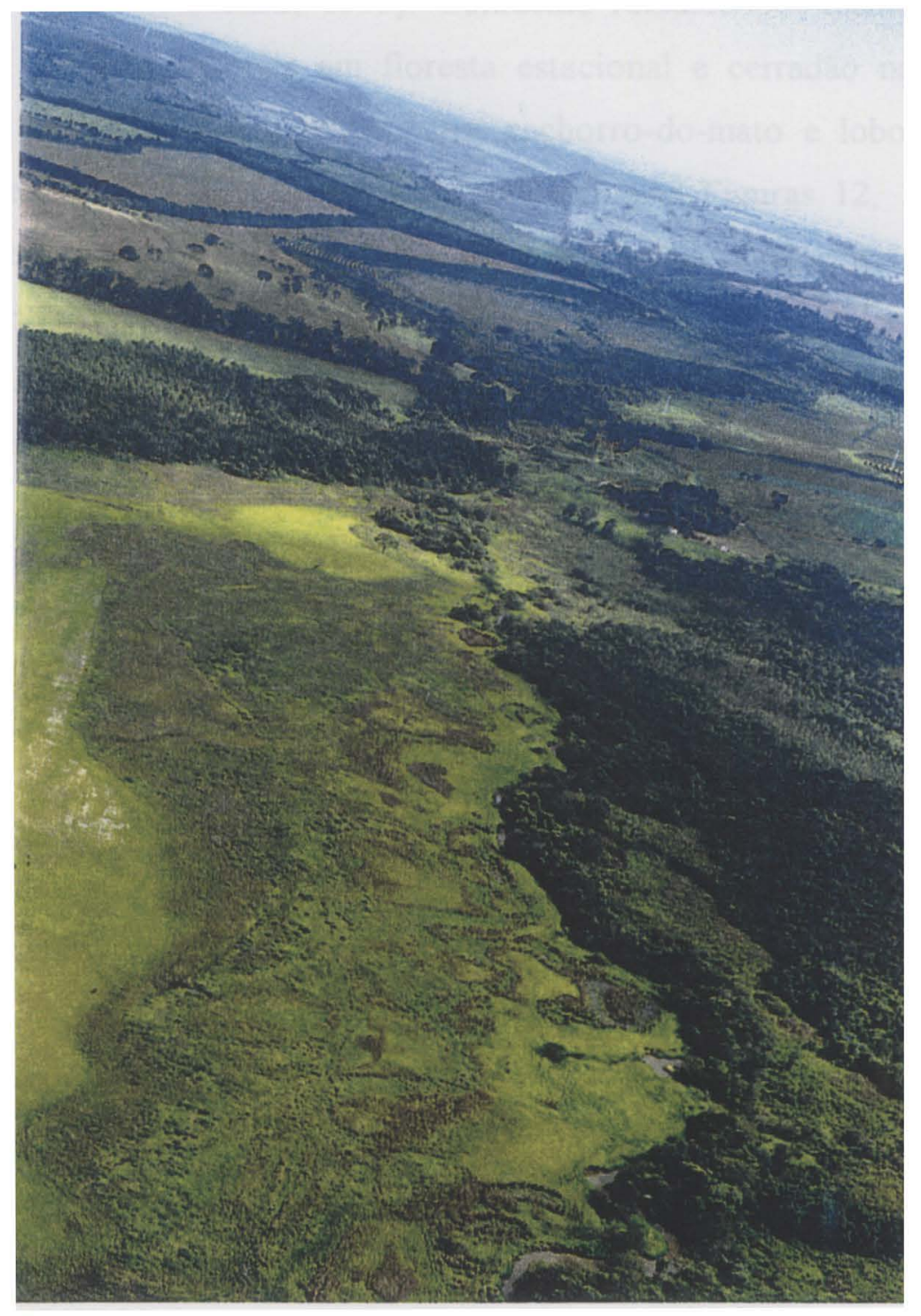

Figura 11 - Vista de parte da área de preservação permanente marginal ao Rio do Pântano, no município de Descalvado (SP) (DEPRN/ET São Carlos) 
A ocorrência de elevada diversidade de espécies na área de estudo é confirmada através de resultados de levantamentos faunisticos e florísticos realizados na Estação Ecológica do Jataí - EEJ, localizada no município limitrofe de Luiz Antônio, na mesma bacia hidrográfica, portanto, com ampla similaridade ambiental com a área de estudo. A EEJ apresenta uma área de apenas $4.532,18$ ha, onde foram identificadas 186 espécies de vegetais, 224 espécies de aves, 46 de serpentes e 32 de peixes (TOLEDO FILHO, 1984; PINTO, 1992; CASTELUCCI, 1995; DIAS FILHO, 1994; TALAMONI, 1996; DALMOLIN, 1999, PIRES, 1999). Conforme relatado por técnicos do DEPRN, foi observada, durante vistorias em floresta estacional e cerradão na área de estudo, a ocorrência de veado catingueiro, tatus, cachorro-do-mato e lobo-guará, espécies da fauna silvestre regional ameaçadas de extinção. As Figuras 12, 13 e 14 apresentam pegadas de animais da fauna silvestre fotografadas na região rural de Descalvado, por técnicos do DEPRN/DAIA/SMA.

TALAMONI et al. (1994) citam, entre as espécies críticas, o lobo-guará (Chrysocyon brachyurus), ameaçado pela fragmentação e destruição do cerrado, e que consta da lista oficial do IBAMA como uma das espécies da fauna brasileira (e do Estado de S, Paulo) ameaçadas de extinção. Estão também apontadas como espécies ameaçadas ou vulneráveis: a onça parda (Felis concolor), a jaguatirica (Felis pardalis), o tamanduá-bandeira (Myrmecophaga tridactyla), o cateto (Tayassu tajacu), o sauá (Callicebus personatus), a cuica-lanosa (Caluromys lanatus) e o bugio (Alouatta caraya). A fragmentação progressiva e conseqüente perda de habitats vem causando a preocupante redução da diversidade faunística na região.

$\mathrm{Na}$ área de estudo, o lobo-guará é considerado como espécie-chave, pois, como elemento de topo na rede trófica, constitui importante referencial para pesquisas, servindo para avaliar a extensão de territórios, o funcionamento dos ecossistemas e definir planos de manejo (PIRES e al., 2000).

A análise ambiental voltada ao planejamento focaliza a diversidade de ecossistemas ou habitats, conforme abordagem adotada no presente trabalho, uma vez que a diversidade biológica ao nivel de espécies e genes é extremamente dificil de ser avaliada. 


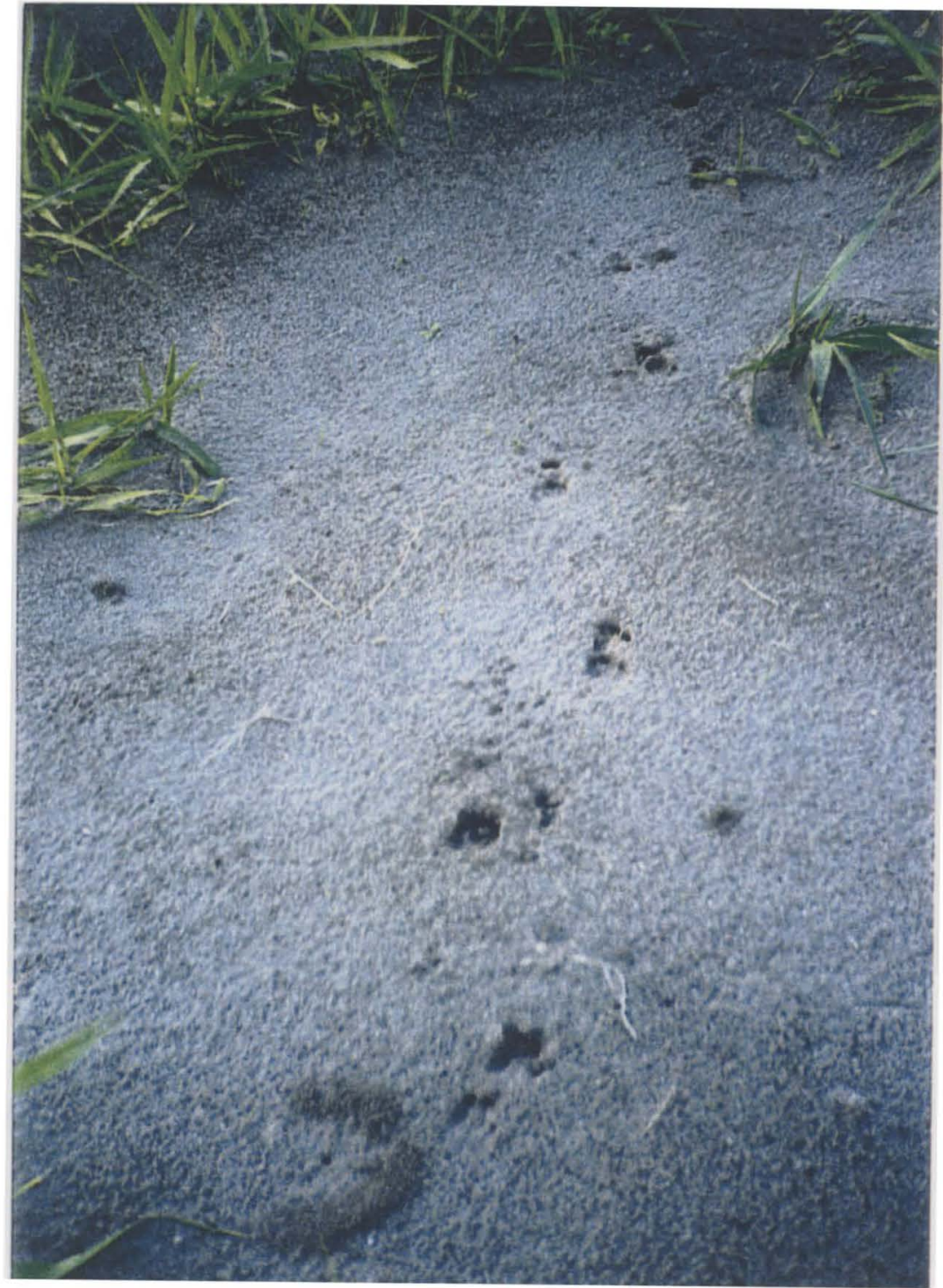

Figura 12 - Pegadas de fauna silvestre fotografadas na região (DEPRN/DAIA, 1999) 


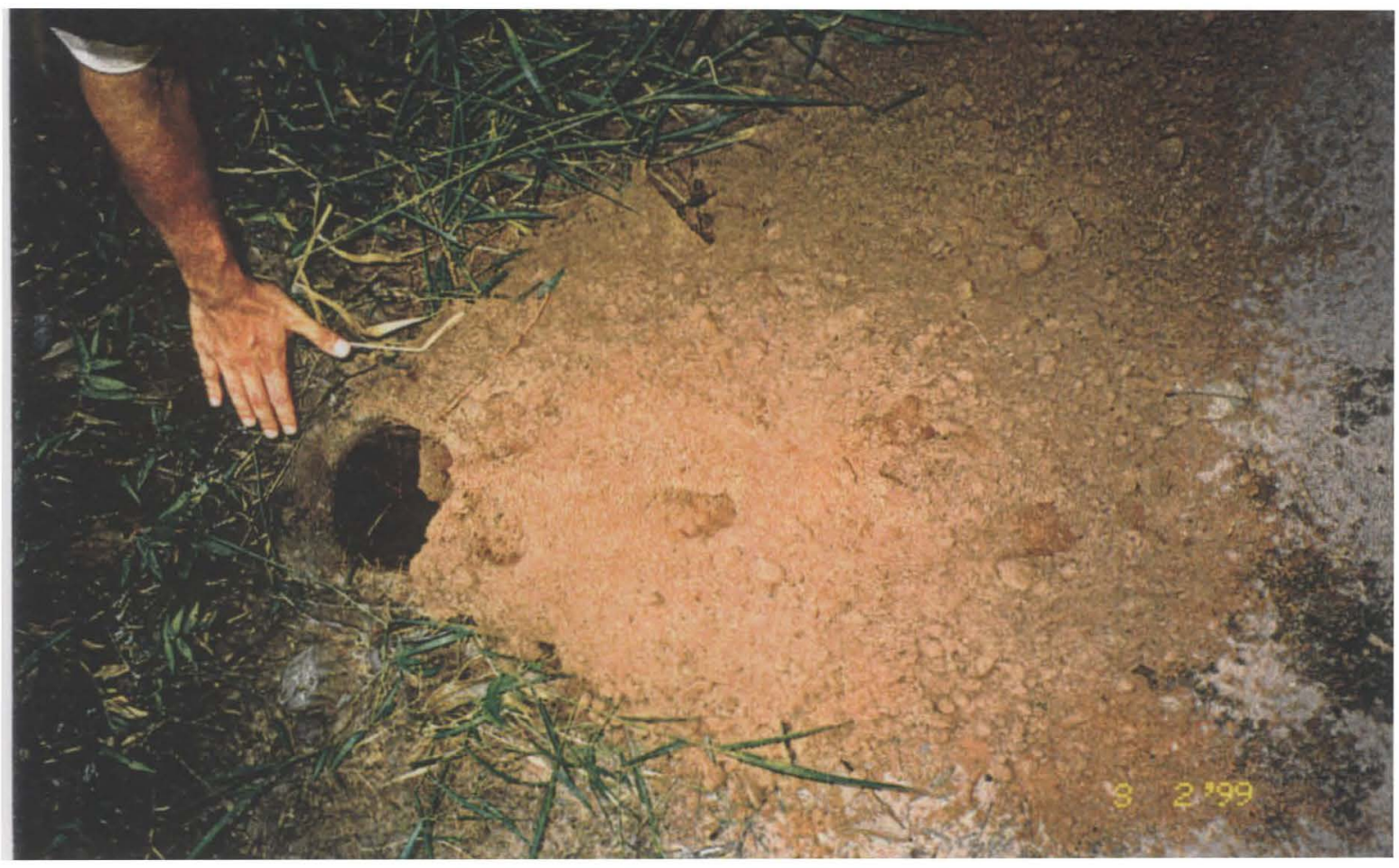

Figura 13 - Pegadas de fauna silvestre fotografadas na região (DEPRN/DAIA, 1999) 


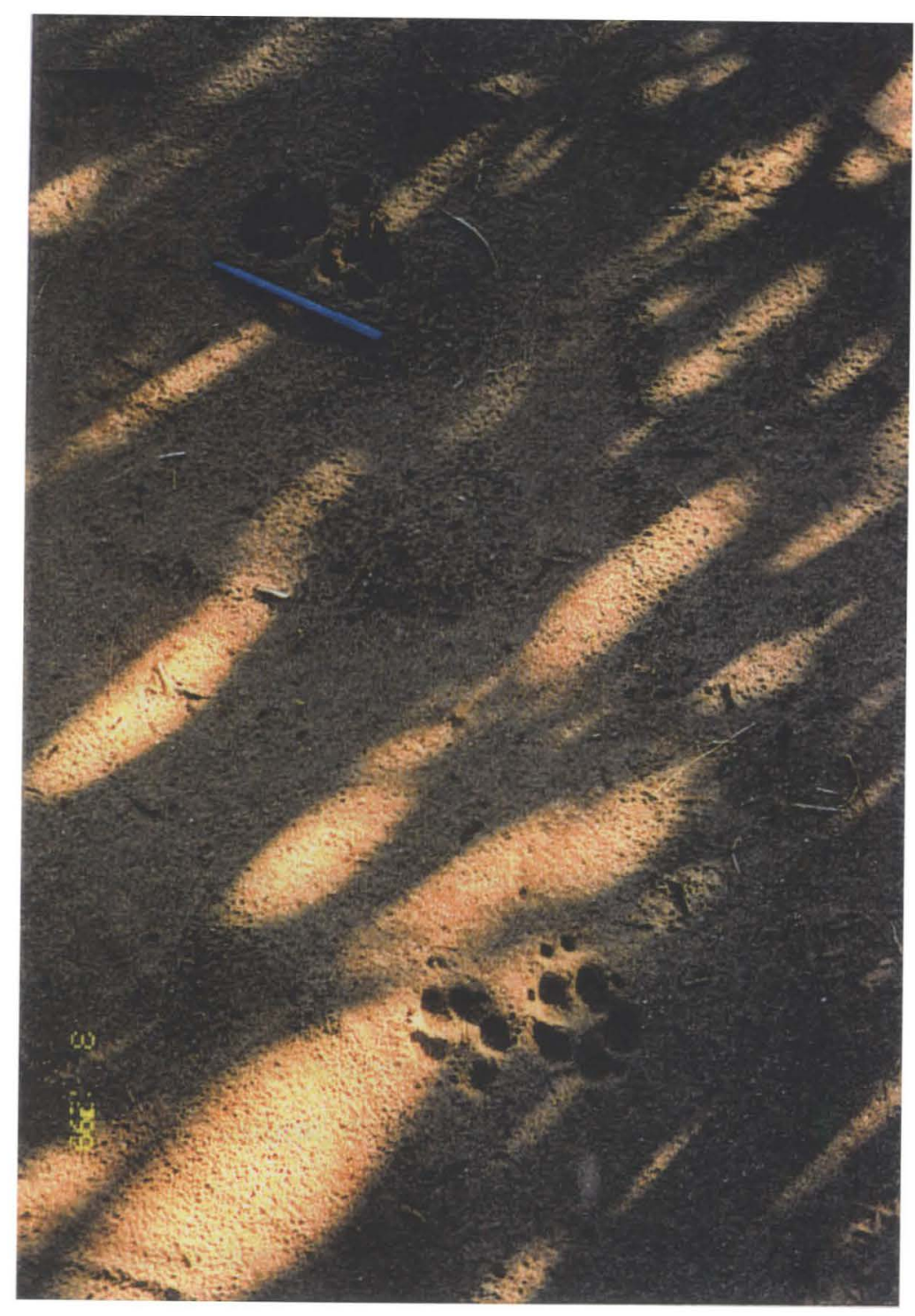

Figura 14 - Pegadas de fauna silvestre fotografadas na região (DEPRN/DAIA, 1999)

\subsubsection{Identificação dos fragmentos de vegetação natural}

De acordo com o levantamento de vegetação nativa efetuado através do "Projeto Olho Verde", da Secretaria do Meio Ambiente (SÃO PAULO, 1995), o município de Descalvado apresentava, em 1989/1990, 4.952 ha de vegetação nativa em seus 79.400 ha, ou seja, 6,49\% de sua área, com a seguinte distribuição: 1.041 ha de mata, correspondente a $1,31 \% ; 1.900$ ha de cerradão, correspondente a $2,39 \%$ e 2.011 ha de 
cerrado, correspondente a $2,53 \%$. Salienta-se que, embora a fonte citada refira a área do Município com 79.400 ha, o IBGE a aponta com 75.720 ha, valor que está sendo assumido nas interpretações efetuadas no presente trabalho.

Como base para as discussões deste trabalho, foram utilizados alguns aspectos conceituais do âmbito da Ecologia da Paisagem e adotados por PIRES (1995) em seus trabalhos de análise ambiental voltados ao planejamento e gerenciamento do ambiente rural. O presente trabalho utiliza a caracterização macroambiental do município de Descalvado como unidade de extensão geográfica, considerando como base a heterogeneidade da paisagem, que, no caso, é determinada pelas manchas de fragmentos de vegetação natural nos limites do município, registradas através da fotointerpretação de imagem de satélite georreferenciada e vistorias em campo.

A análise da imagem de satélite LANDSAT TM (1997) utilizada neste estudo mostrou que a cobertura de vegetação natural no municipio é de aproximadamente $14.397,61$ ha, que representa cerca de $19 \%$ da área total, incluindo as áreas com cobertura vegetal arbustiva e herbácea encontradas em áreas alagáveis, conforme pode ser visto na Figura 15. Este resultado pode apresentar alterações após avaliações de campo mais freqüentes e detalhadas; além disso, é comum encontrar-se resultados diferentes, devido a diferenças metodológicas.

Através da análise da imagem de satélite (Figura 3), foram identificados 684 fragmentos de vegetação natural, distribuidos conforme consta da Tabela 4.

Tabela 4 - Distribuição dos fragmentos de vegetação natural registrados na imagem LANDSAT, 1997.

\begin{tabular}{ccccc}
\hline Classe (ha) & $N^{\text {0 de Fragmentos }}$ & $\%$ de fragmentos & Área (ha) & \% da área \\
\hline 0,1 a 5,0 & 398 & 58,19 & 815,29 & 5,65 \\
5,1 a 20,00 & 177 & 25,87 & 1710,20 & 11,85 \\
20,1 a 100 & 82 & 11,99 & $3.506,98$ & 24,80 \\
$>100$ & 27 & 3,95 & $8.365,14$ & 58,10 \\
\hline TOTAL & 684 & 100 & $14.397,61$ & 100 \\
\hline
\end{tabular}


Em relação ao tamanho dos fragmentos, pode-se verificar que a maioria dos mesmos é de tamanho muito reduzido (entre 0,1 e 5,0 ha), recobrindo uma área de aproximadamente 815 ha. Outros 177 fragmentos são considerados de tamanho pequeno (entre 5,1 e 20,0 ha) e ocupam uma área de 1.710 ha. Os fragmentos considerados de tamanho médio, em função do perfil de distribuição (20 a $100 \mathrm{ha}$ ), representam quase $25 \%$ da área vegetada (Figuras 16 e 17).

Apenas 27 fragmentos apresentam tamanho superior a 100 ha, e naturalmente, muitos destes, especialmente os maiores, são constituidos de diversos tipos interconectados de ecossistemas, incluindo matas ripárias, áreas alagáveis e vegetação florestal. Além disto, podem ter sido considerados como uma única mancha devido à interpretação da imagem de satélite que, muitas vezes, não leva em consideração estradas de pequeno tamanho que os cortam e, em uma aproximação mais detalhada, possivelmente seriam separados em fragmentos menores.

As áreas referidas no presente trabalho como fragmentos de vegetação natural são consideradas remanescentes da cobertura original da área de estudo, que era composta por matas (florestas estacionais semi-deciduais), cerradões, cerrado senso estrito, campos cerrados, mata ripária ou ciliar e outras formações vegetais conhecidas por banhados, brejos ou várzeas. 


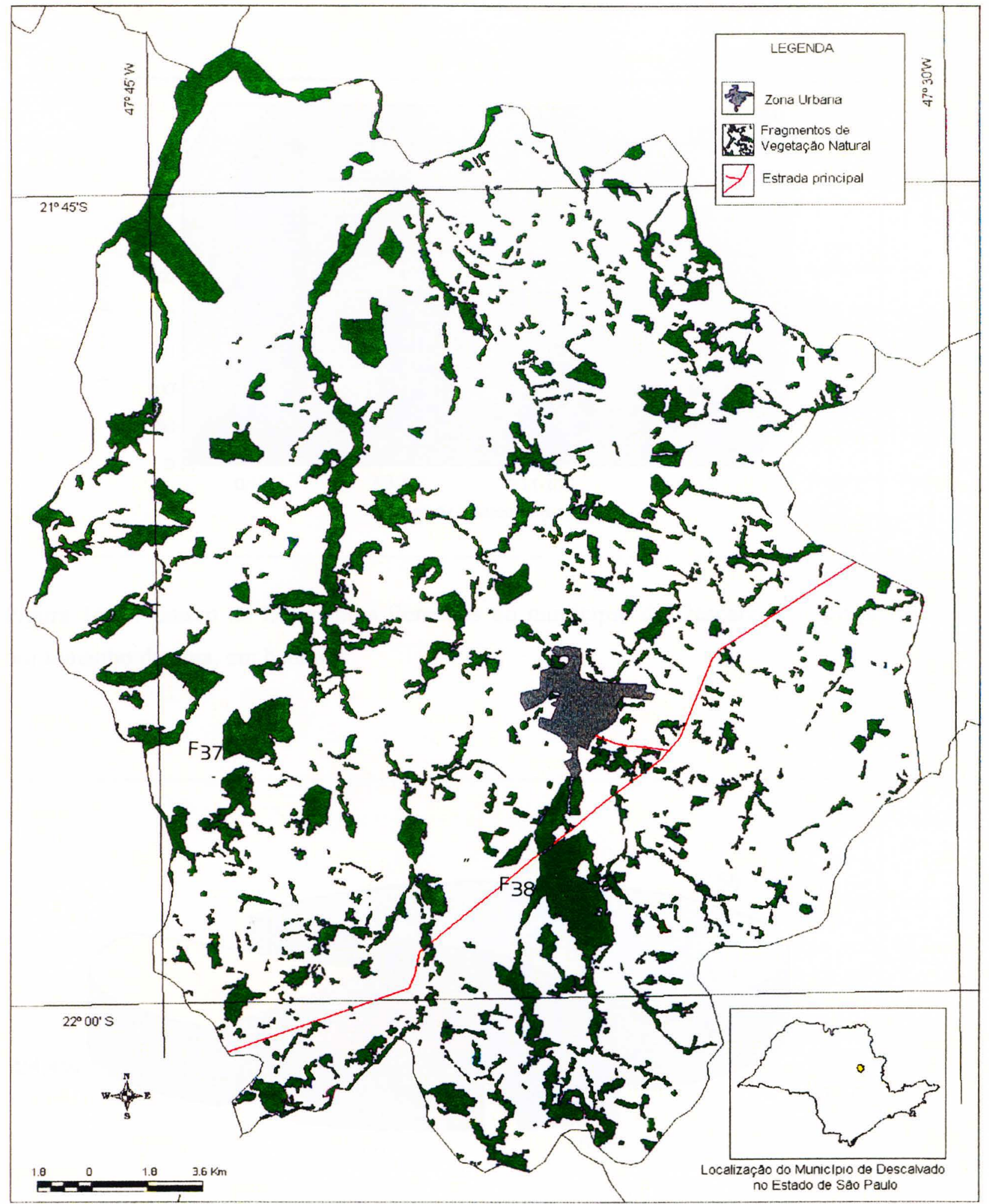

Figura 15 - Fragmentos de vegetação natural no município de Descalvado, SP , obtidos a partir da digitalização da imagem TM Landsat 1997 (UFSCAR/LAPA, 2000). 


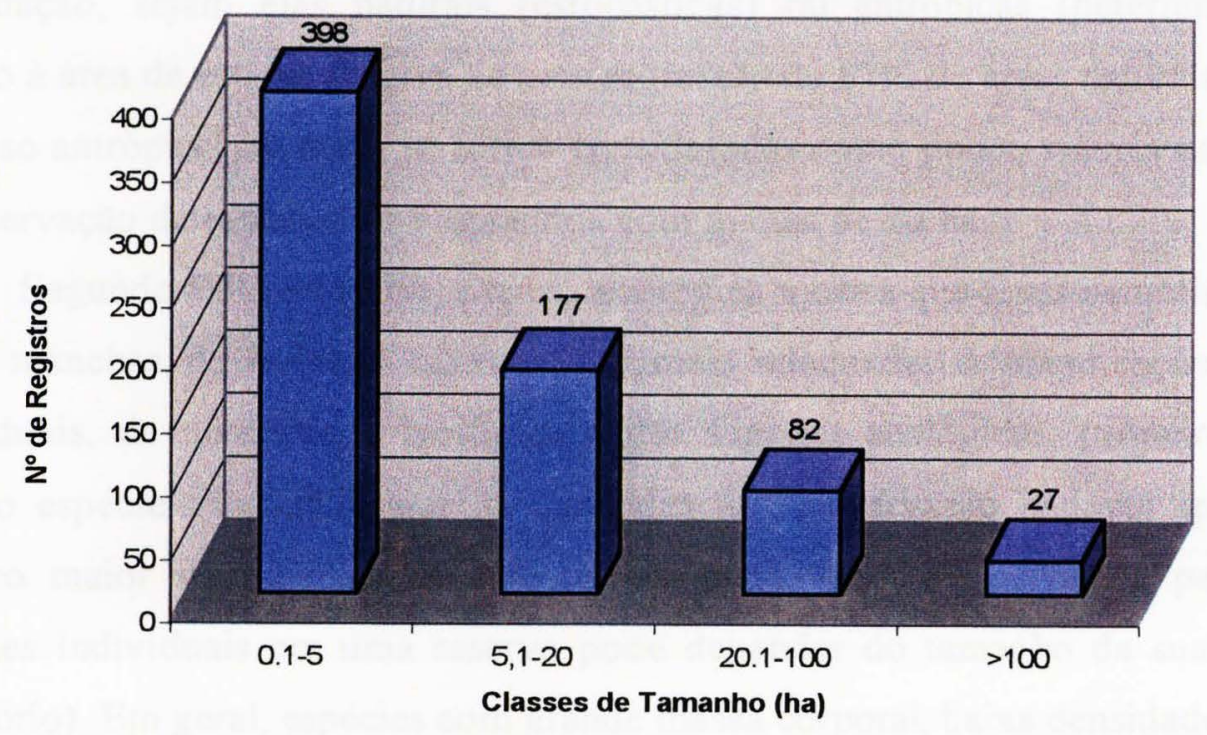

Figura 16 - Número de fragmentos florestais do município de Descalvado, agrupados por tamanho de área, em hectares.

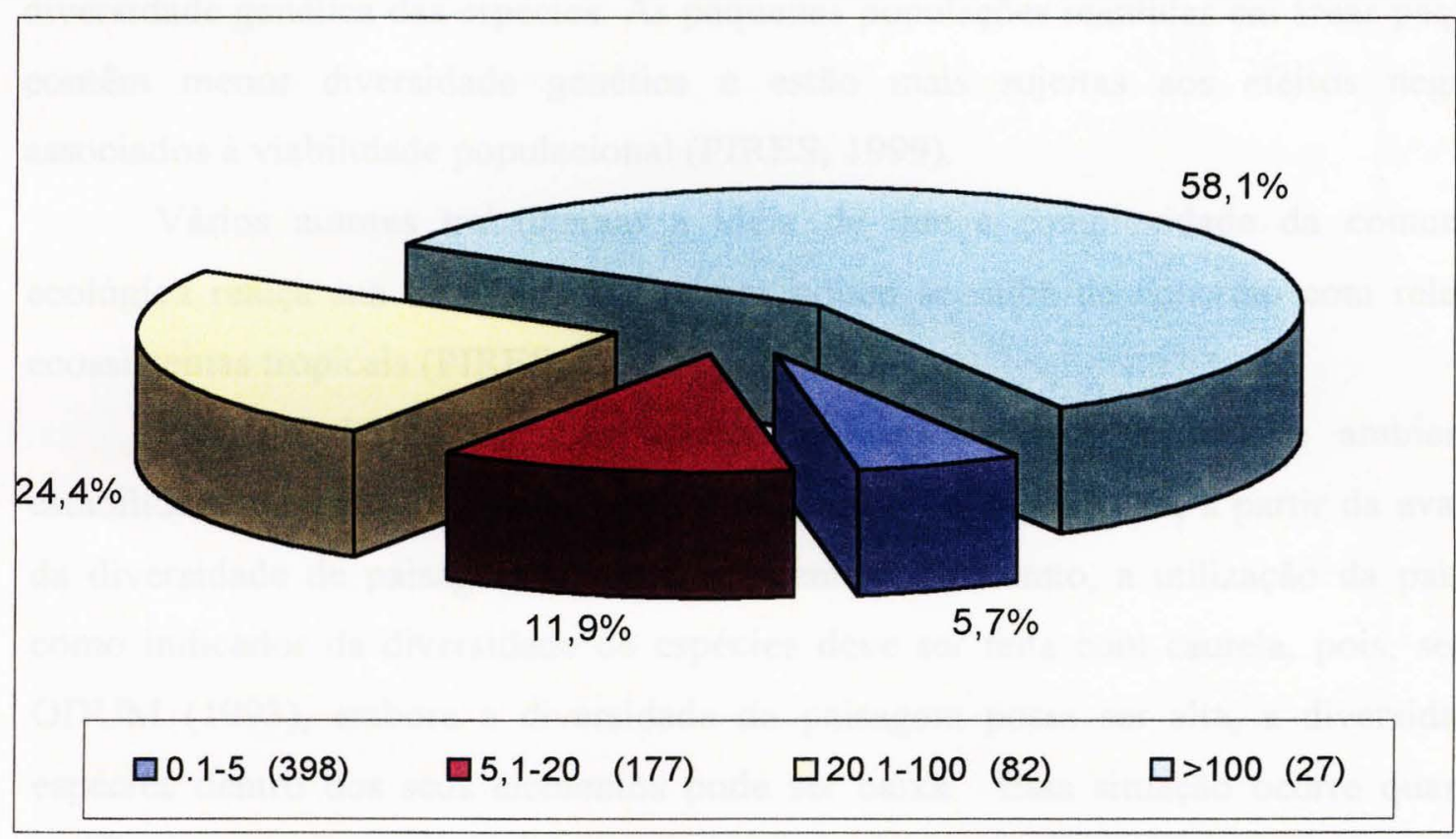

Figura 17 - Porcentagem de área de vegetação natural ocupada, por classes de fragmentos; na legenda, consta também o número de fragmentos por classe. 
Considerando que esses fragmentos remanesceram das diversas formas de perturbação, sejam elas naturais (estocásticas) ou antrópicas (deterministicas), em relação à área de estudo observa-se uma regressão de $81 \%$ de áreas naturais, convertidas para uso antrópico, ou mais, se forem consideradas como pouco viáveis na manutenção e conservação de espécies os fragmentos com menos de 20 ha.

Segundo PIRES (1999), a teoria ecológica mostra que áreas naturais (fragmentos como manchas de habitats maiores são mais adequadas à manutenção de espécies individuais, da diversidade biológica e das funções ecológicas; primeiro, porque a relação espécie/área indica que as Unidades de Conservação maiores apresentam um número maior de espécies do que as menores; segundo, porque a persistência de espécies individuais em uma reserva pode depender do tamanho de sua própria área (território). Em geral, espécies com grande massa corporal, baixa densidade e de topo de cadeia alimentar, com grande necessidade de espaço individual, necessitam de grandes áreas para manter populações viáveis por longo tempo. Ao contrário, espécies com pequenas massas corporais, alta densidade e nível trófico inferior necessitam de pequeno espaço individual.

Outra preocupação com relação ao tamanho das áreas é a manutenção da diversidade genética das espécies. As pequenas populações mantidas em áreas pequenas contêm menor diversidade genética e estão mais sujeitas aos efeitos negativos associados à viabilidade populacional (PIRES, 1999).

Vários autores trabalharam a idéia de que a complexidade da comunidade ecológica realça sua estabilidade, embora pouco se saiba de concreto com relação a ecossistemas tropicais (PIRES, 1995).

Partindo deste princípio, poder-se-ia considerar a capacidade ambiental e estabilidade de uma área, neste caso, o município de Descalvado, a partir da avaliação da diversidade de paisagens naturais existentes. Entretanto, a utilização da paisagem como indicador da diversidade de espécies deve ser feita com cautela, pois, segundo ODUM (1993), embora a diversidade da paisagem possa ser alta, a diversidade de espécies dentro dos seus elementos pode ser baixa. Essa situação ocorre quando se verifica, como nesse estudo de caso, a elevada ocorrência de muitos fragmentos pequenos ( 5,1 a 20 ha) e muito pequenos ( 0,1 a 5 ha), que, embora aumentem a diversidade da paisagem, contêm menor diversidade de diversidade de espécies devido 
aos efeitos negativos decorrentes da fragmentação e efeitos de borda e perturbações do entorno.

Do ponto de vista de conservação da biodiversidade, o ambiente dentro dos fragmentos deve ser examinado não somente sob o aspecto quantitativo, como também sob o aspecto qualitativo, pois ambos contribuem para determinação do número de indivíduos de uma espécie que podem ser encontrados dentro de um fragmento. A qualidade inclui o estado fisico do ambiente (incluindo a rede trófica) aliado ao fenótipo da população, como por exemplo abundância de recursos, ocorrência de perturbações, interação entre espécies (competidores, predadores, entre outros). Assim sendo, fragmentos naturais que possuem pouca diversidade de habitats no seu interior possuem menor chance de sustentar alta diversidade de espécies e populações Neste caso, a maioria das populações existentes possivelmente não poderá sobreviver a longo termo, pois, quanto menor a população, maior é a sua vulnerabilidade a perturbações e possibilidades de recuperação.

Diversos autores, citados por PIRES (1995), estudaram a formação de fragmentos, especialmente após um evento grave de perturbação, como a formação de ilhas decorrentes de construção de reservatórios. Nesses casos, o tamanho da população varia rapidamente, como resultado da morte ou danos individuais. Certas espécies tornam-se extintas localmente, ou migram, desaparecendo da área. Algumas podem sobreviver e permanecer em formas dormentes (esporos, sementes, cistos) ou populações reduzidas. $\mathrm{O}$ número de individuos das populações remanescentes pode crescer, dependendo das condições ambientais do fragmento (sucessão). Tem-se também a recolonização pela imigração, com a chegada de espécies mais adaptadas às novas condições do habitat. Esta seqüência de respostas à perturbação determina um certo equilíbrio no fragmento; entretanto, sua situação de isolamento frente às áreas adjacentes e o impacto permanente das atividades do entorno pode impedir o seu retorno ao estado natural anterior à fragmentação.

No caso em estudo, os tipos de perturbação sofrida pelos fragmentos podem ser classificados como agudos, pelo corte raso de grande parte da vegetação natural (em até $80 \%$ de sua área), e crônicos, como impacto de isolamento entre as áreas de vegetação natural e das atividades antrópicas circundantes, tais como agricultura, mineração, estradas com elevado fluxo de veículos, entre outros. Os principais riscos sobre os 
fragmentos naturais verificados na área de estudo e decorrentes das atividades agrícolas desenvolvidas no entorno são: o fogo e a contaminação e eliminação biológica por agrotóxicos. Além destes, pode-se citar a coleta e caça de exemplares de animais e flora silvestre, principalmente naqueles situados próximo de estradas e zonas urbanas. A título de exemplo, estão inseridas as Figuras 18, 19 e 20, indicando algumas perturbações agudas (decorrentes dos desmatamentos) e crônicas (pelas atividades do entorno) verificadas na área de estudo.

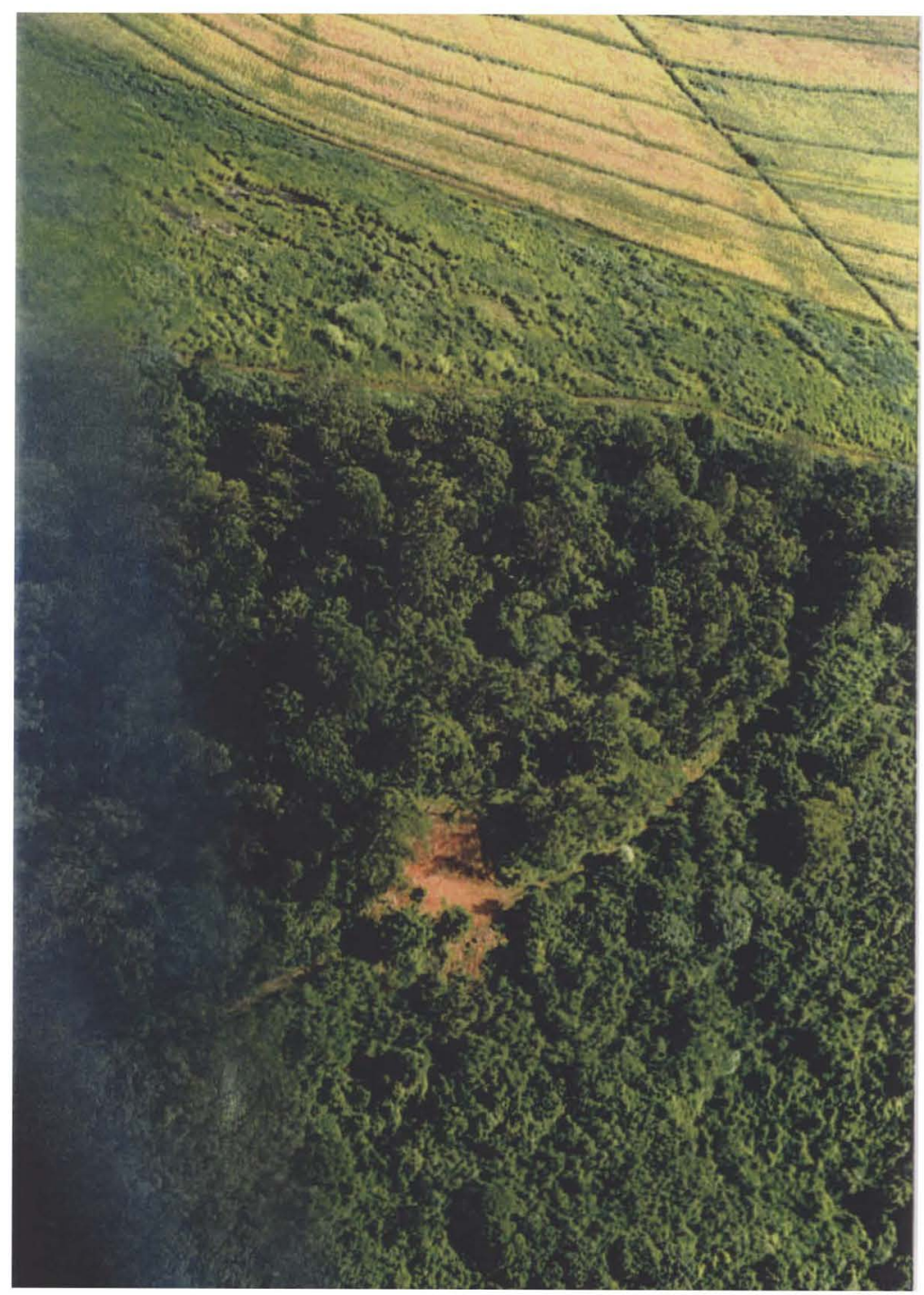

Figura 18 - Retirada de cascalho dentro de uma Reserva Legal de Floresta Estacional Semi-Decídua no município de Descalvado (SP) (SMA/DEPRN/ET São Carlos). 


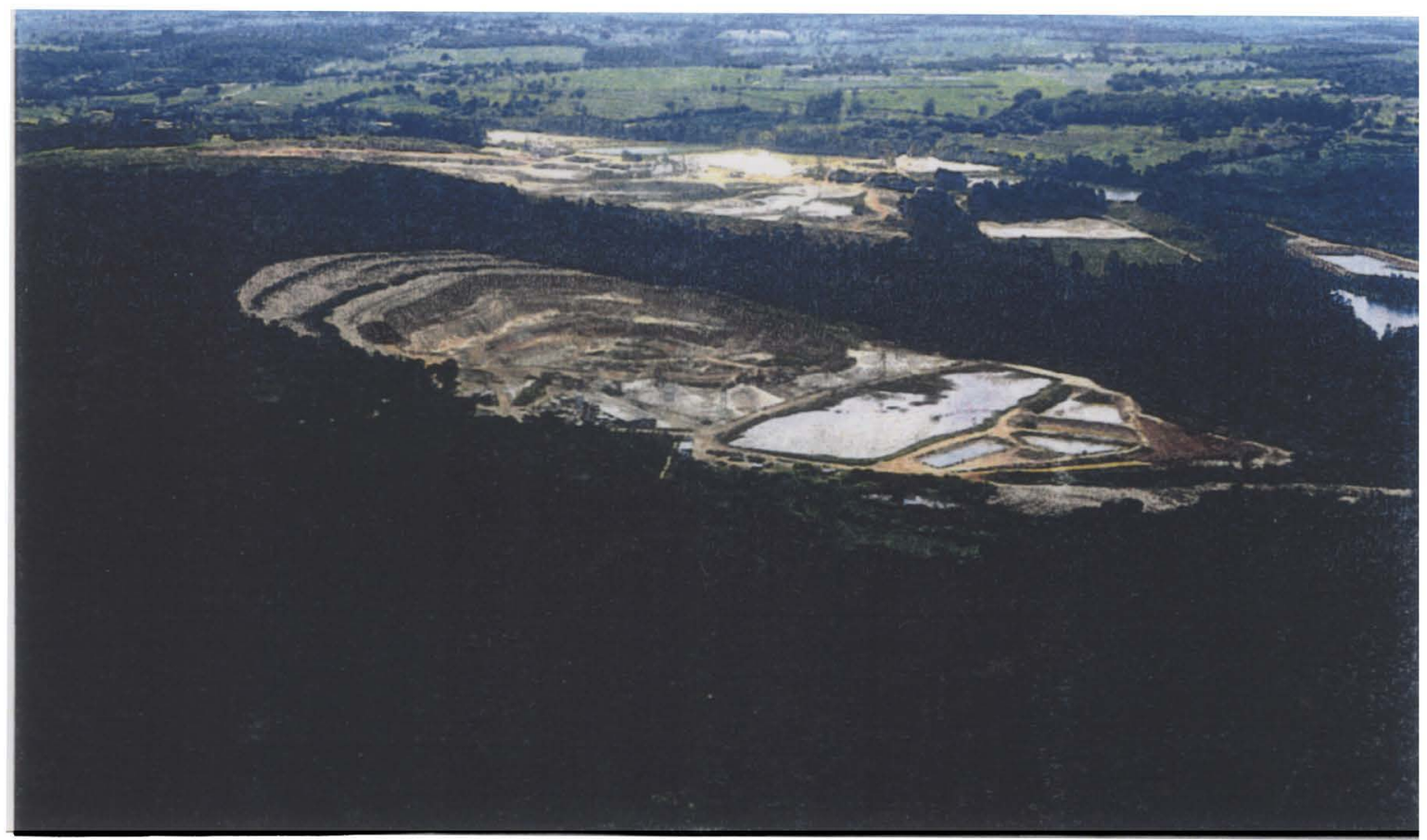

Figura 19 - Desmatamento autorizado para atividade de mineração, dentro de extenso fragmento de cerrado no Município de Descalvado (SP) (SMA/DEPRN/ET São Carlos).

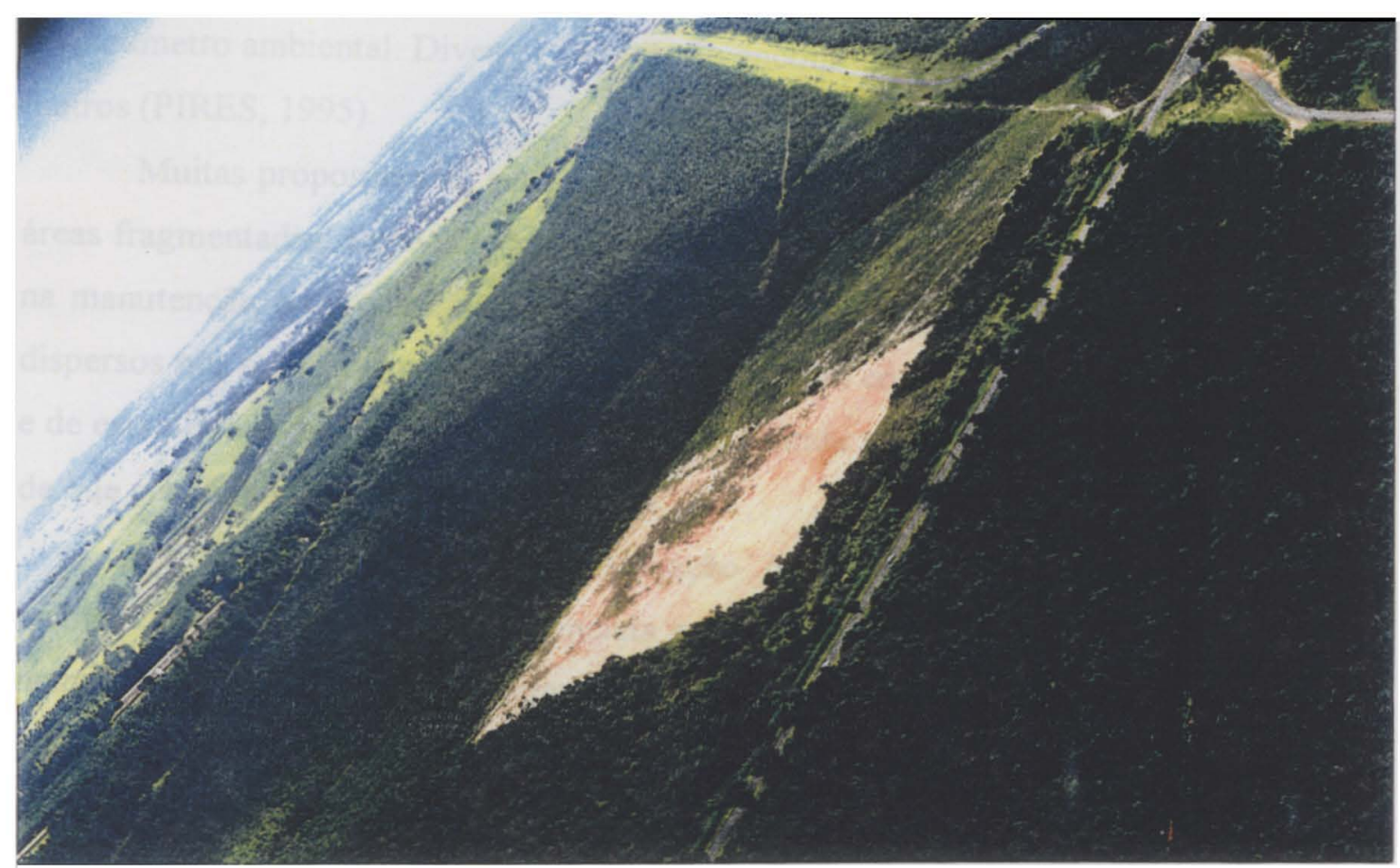

Figura 20 - Desmatamento não autorizado realizado para implantação de Distrito Industrial dentro de extenso fragmento de cerrado no Município de Descalvado (SP). Note-se a proximidade da área urbana e estradas cortando o fragmento (SMA/DEPRN/ET São Carlos). 
LINDBERG, citado por PIRES (1995), afirma que a fragmentação e o isolamemto das áreas naturais e devido a atividades antrópicas no entorno aproximam estas áreas da situação de ilha, que serve como barreira para o deslocamento das espécies. Nesse sentido, os pesquisadores que trabalham com a biologia da conservação de espécies desenvolveram um modelo conhecido como "biogeografia de ilhas", no qual a teoria do equilibrio entre extinções locais e recolonizações auxilia o entendimento e resolução de alguns aspectos relacionados à conservação desses fragmentos.

O efeito de borda é um fator de inquestionável importância sobre o número, tipo e fluxo de espécies, e está relacionado tanto ao tamanho como à forma do fragmento. Quanto maior a distância entre as bordas e o centro do fragmento, maior é a proteção das espécies do interior deste em relação às perturbações externas. Portanto, fragmentos grandes, apresentando formas mais próximas do círculo, teoricamente apresentam menor vulnerabilidade às ameaças externas. $O$ efeito de borda varia conforme a espécie ou parâmetro ambiental. Diversos limites são encontrados na literatura, desde 10 até 600 metros (PIRES, 1995).

Muitas propostas têm sido apresentadas para conservação da biodiversidade em áreas fragmentadas, entre elas a utilização de "corredores". Esses corredores consistem na manutenção e ou criação de ligações entre grandes fragmentos centrais e pequenos dispersos nos seus entornos, e em certa escala podem contemplar a idéia de manutenção e de estabilidade de uma paisagem. Entretanto, ainda não existem evidências científicas de que eles funcionem (PIRES, 1995).

Os aspectos relativos à conservação da vegetação para proteção de áreas ambientais relevantes, como mananciais e encostas, são motivos suficientes para sua manutenção. Entretanto, para cumprir a função ecológica de "corredores", devem ser efetuados estudos no sentido de verificar a sua eficácia com relação a permitirem o trânsito de espécies entre os fragmentos. As áreas marginais ao Rio do Pântano, que interligam as áreas montanhosas ao sul do município ao Rio Mogi-Guaçu, apresentam condições teóricas ideais para cumprir esta função, conforme pode ser visto na Figura 11. Entretanto, a ocupação por atividades antrópicas de áreas marginais a corpos d'água (conforme pode ser visto na Figura 21), proibidas por Lei, foi situação amplamente 
encontrada na área de estudo, especialmente pelo cultivo de cana-de-açúcar, manutenção de pastagens e ranchos de pesca nas áreas de preservação permanente.

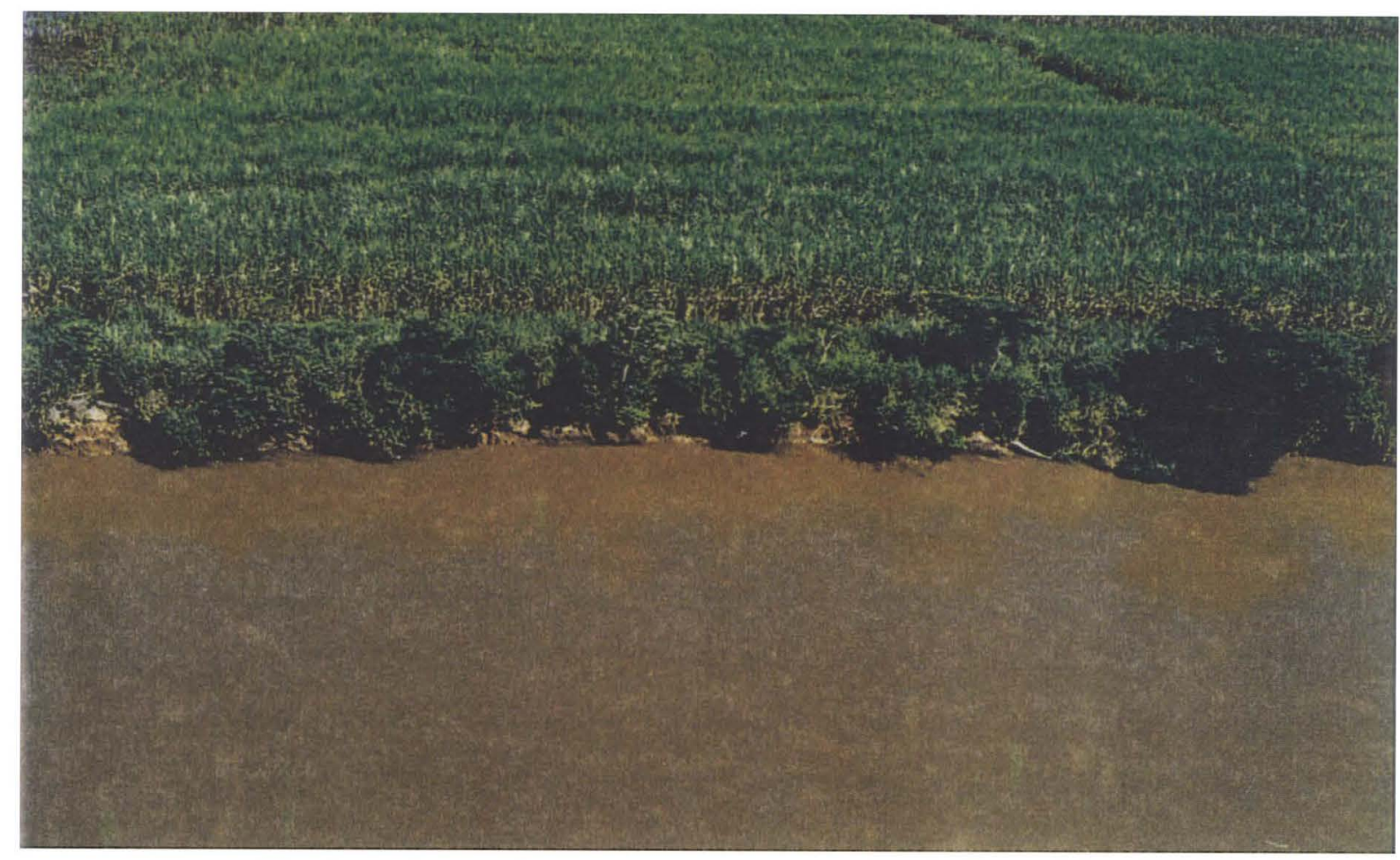

Figura 21 - Ocupação da margem do Rio Mogi-Guaçu por cultura de cana-de-açúcar, no município de Descalvado (SP) (SMA/DEPRN/ET São Carlos).

Toda a microbacia do Rio do Pântano encontra-se inserida na APA municipal de Descalvado, cuja criação foi subsidiada por estudos acadêmicos, dentre os quais a dissertação realizada por OLIVEIRA (1995), que estabeleceu inicialmente seus limites através da presença de elementos naturais de importância tanto regional como local, tais como: heterogeneidade da paisagem, condicionada pela presença da Serra Geral; potencial recreativo e turístico de sítios como o Salto do Pântano; ocorrência de remanescentes de vegetação com ocorrência de fauna endêmica e algumas em extinção, e fragilidade de ecossistemas que podem comprometer a produção de recursos essenciais (mananciais) e a produtividade agrícola. Para realização do referido estudo, a autora utilizou a técnica de geoprocessamento com sobreposição de cartas temáticas, com a descrição de aspectos físicos, biológicos, antrópicos e legais, integrando-as através do um Sistema Geográfico de Informações - SIG, de forma a gerar mapas 
sintese que possibilitaram, juntamente com o trabalho de campo, estabelecer diretrizes para o uso do solo, delimitação e regulamentação da APA Municipal.

$\mathrm{Na}$ análise da cobertura de vegetação natural efetuada no macrozoneamento das bacias dos rios Mogi-Guaçu, Pardo e Médio Grande (SÃO PAULO, 1995), foi apontada a grave redução dessas áreas, com uma preocupante perda da diversidade animal e vegetal. Neste estudo, foram selecionados no município de Descalvado dois fragmentos (F37 e F38, Figura 22) de cerrado e cerradão considerados relevantes para serem preservados como unidades de conservação. Contudo, na análise dos fragmentos obtidos da imagem Landsat 1997 e excursões a campo, verificou-se que os fragmentos mencionados (F37 e F38) foram altamente subdivididos e reduzidos, através de licenciamento, embora constituam ainda duas importantes áreas para conservação (Fig. $15)$.

À luz de todas essas considerações, verifica-se, na avaliação do quadro de fragmentação de vegetação natural obtido, a elevada ocorrência de fragmentos muito pequenos e pequenos (de 0,1 a 20 ha - 298 fragmentos), indicando que a área de estudo encontra-se sob forte pressão negativa em decorrência da atividade antrópica. Este quadro de extrema fragmentação, tanto sob o aspecto quantitativo como qualitativo, demonstra a grande importância na manutenção de todos os fragmentos florestais da área de estudo, bem como a necessidade de favorecer as ligações com outras áreas que tenham relevância na manutenção da diversidade biológica. Existem, nos municípios vizinhos e mesmo compartimento da bacia hidrográfica, três áreas legalmente protegidas, que poderiam servir como pontos de referência para diminuir os impactos da fragmentação, numa estratégia de conservação inter situ (PIRES et al., 2000). São elas: Parque Ecológico de Porto Ferreira, com 611, 55 ha de Mata Atlântica e cerrado, criado em 1981; Parque Ecológico da Vassununga, em Santa Rita do Passa Quatro, com 832,14 ha de Mata Atlântica, criado em 1970; e a Estação Ecológica do Jataí, com área de 4.532, 18 ha de cerrado, criada em 1982 (PIRES, 1999).

Com relação ao trabalho de campo, vistoriou-se 13 pontos, identificados por números com uma caneta de retroprojetor sobre uma transparência fixada na grade ("grid") em UTM, esta sobreposta à imagem georreferenciada de satélite. Com utilização do GPS anotou-se, em folha à parte, as coordenadas UTM e informações fisionômicas (cerrado ou floresta), estado de conservação (bom ou mau) e status legal 


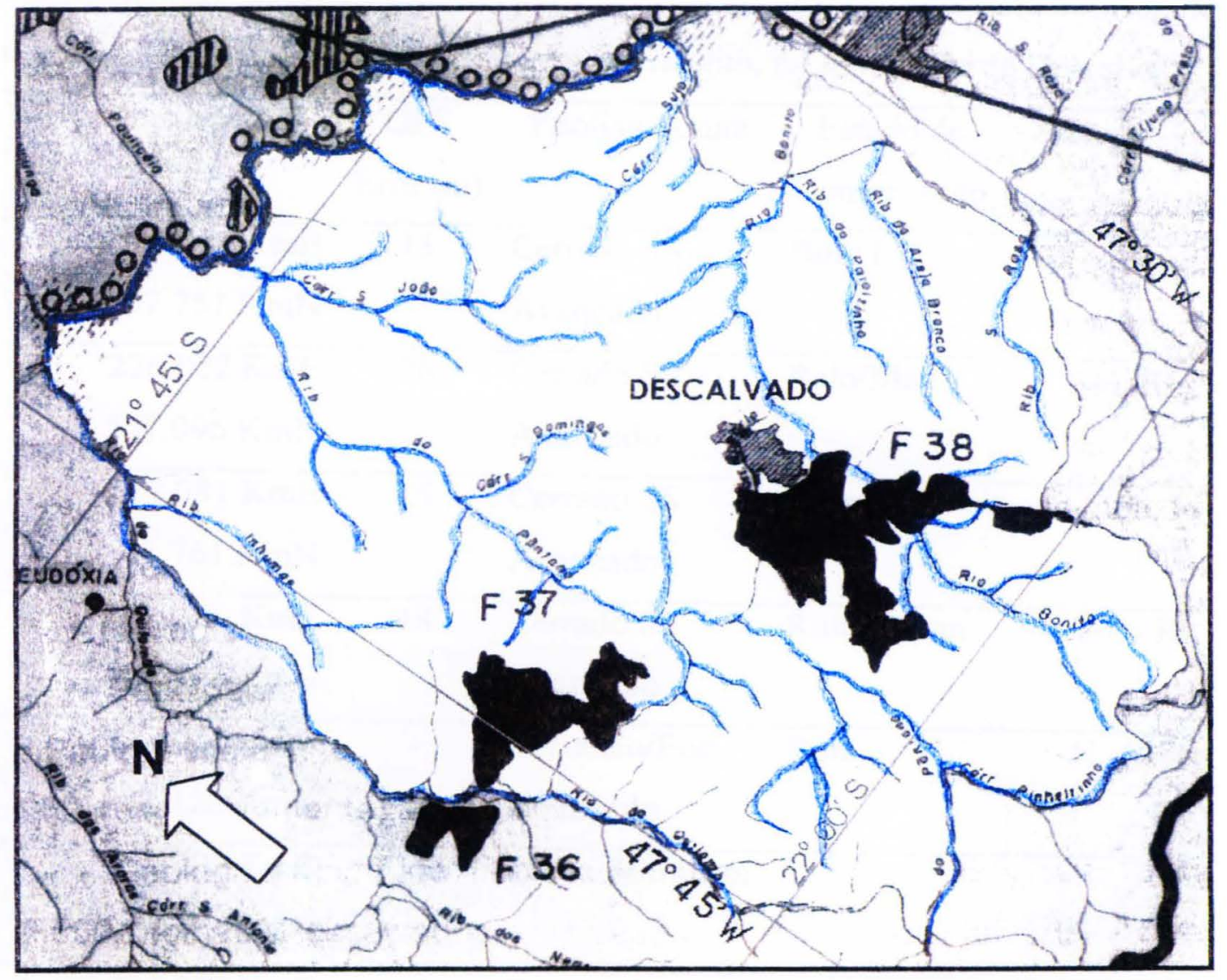

Figura 22 - Remanescentes de vegetação natural do município de Descalvado (F37 e F38) indicados como áreas de interesse para implantação de Unidades de Conservação no Projeto de Macrozoneamento das bacias dos rios Mogi-Guaçu, Pardo e Médio Grande (modificado de RANIERI, 2000)

quando se dispunha da informação (Reserva Legal ou não). Ressalta-se que o trabalho de campo foi em muito facilitado pela utilização desses instrumentos, acrescentando segurança e rapidez às práticas de campo. A condição de contar com a informação de fragmentação de ampla área de entorno, em campo, possibilita a visualização do fragmento de vegetação vistoriado como elemento da paisagem, inserindo a visão ecossistêmica preconizada ao longo de todo esse trabalho. Não se encontrou nenhuma dificuldade operacional no trabalho de campo. Foram vistoriados os pontos relacionados na Tabela 5. 
Tabela 5 - Localização (em UTM) e avaliação de campo de alguns fragmentos de vegetação natural, com GPS e Imagem de Satélite, no município de Descalvado (SP).

\begin{tabular}{|c|c|c|c|c|c|}
\hline $\mathrm{N}^{\circ}$ & $\begin{array}{c}\text { Localização } \\
\text { UTM }\end{array}$ & $\begin{array}{c}\text { GPS } \\
\text { Erro (m) }\end{array}$ & Fitofisionomia & $\begin{array}{c}\text { Estado de } \\
\text { Conservação }\end{array}$ & Situação Legal \\
\hline 1 & $\begin{array}{r}225.878 \mathrm{KmE} \\
7.567 .751 \mathrm{KmN}\end{array}$ & 15 & $\begin{array}{l}\text { Cerrado SS } \\
\text { Avançado }\end{array}$ & Bom (-) & RL \\
\hline 2 & $\begin{array}{r}226.022 \mathrm{KmE} \\
7.567 .096 \mathrm{KmN}\end{array}$ & 26 & $\begin{array}{l}\text { Cerrado SS } \\
\text { Avançado }\end{array}$ & Ralo/Mau & $1 / 2 \mathbf{R L}$ \\
\hline 3 & $\begin{array}{r}227.081 \mathrm{KmE} \\
7.568 .761 \mathrm{KmN}\end{array}$ & 15 & $\begin{array}{l}\text { Cerrado SS } \\
\text { Avançado }\end{array}$ & Bom (-) & $\mathrm{RL}$ \\
\hline 4 & $\begin{array}{c}229.101 \mathrm{KmE} \\
7.570 .488 \mathrm{KmN}\end{array}$ & 18 & $\begin{array}{l}\text { Cerrado SS } \\
\text { Avançado }\end{array}$ & Ruim/Desm & $20 \% \mathrm{RL}$ \\
\hline 5 & $\begin{array}{r}227.930 \mathrm{KmE} \\
7.582 .120 \mathrm{KmN}\end{array}$ & - & $\begin{array}{l}\text { Cerradão/Euc } \\
\text { Avançado }\end{array}$ & Bom & N. Averb \\
\hline 6 & $\begin{array}{r}227.002 \mathrm{KmE} \\
7.583 .551 \mathrm{KmN}\end{array}$ & 15 & Linha de transm. & & \\
\hline 7 & $\begin{array}{r}227.093 \mathrm{KmE} \\
7.584 .875 \mathrm{KmN}\end{array}$ & 14 & $\begin{array}{l}\text { Represa/laranja } \\
\text { Mciliar/pioneiro }\end{array}$ & Replantio & N.Averb. \\
\hline 8 & $\begin{array}{r}226.205 \mathrm{KmE} \\
7.589 .018 \mathrm{KmN}\end{array}$ & 14 & $\begin{array}{l}\text { Cerrado SS } \\
\text { Avançado }\end{array}$ & Bom $(+)$ & RL (?) \\
\hline 9 & $\begin{array}{r}225.893 \mathrm{KmE} \\
7.589 .822 \mathrm{KmN}\end{array}$ & 26 & $\begin{array}{l}\text { Cerradão } \\
\text { Avançado }\end{array}$ & Bom (+) & $\mathrm{RL}(?)$ \\
\hline 10 & $\begin{array}{r}227.381 \mathrm{KmE} \\
7.590 .746 \mathrm{KmN}\end{array}$ & - & - & $\begin{array}{l}- \\
\text { Bom/Ilha }\end{array}$ & - \\
\hline 11 & $\begin{array}{r}229.013 \mathrm{KmE} \\
7.588 .888 \mathrm{KmN}\end{array}$ & 0 & Represa & $\begin{array}{l}\text { Bom }(+) \\
-\end{array}$ & ? \\
\hline 12 & $\begin{array}{r}230.355 \mathrm{KmE} \\
7.587 .713 \mathrm{KmN}\end{array}$ & 0 & $\begin{array}{l}\text { Cerrado SS } \\
\text { Avançado }\end{array}$ & $\begin{array}{l}\text { Bom } \\
\text { Bom (+) }\end{array}$ & $?$ \\
\hline 13 & $\begin{array}{r}234.738 \mathrm{KmE} \\
7.585 .532 \mathrm{KmN}\end{array}$ & 0 & $\begin{array}{l}\text { FLES } \\
\text { Avançado }\end{array}$ & Bom & N.Averb. \\
\hline
\end{tabular}


A maior parte dos fragmentos vistoriados era constituída por cerrado, nas suas diversas formações (de savânicas a florestais), em bom estado de conservação, apesar das atividades verificadas no entorno, decorrentes, em sua maior parte, de atividades agropecuárias (principalmente cana-de-açúcar) e estradas vicinais.

A técnica de geoprocessamento (SIG) vem sendo largamente utilizada para estudos e planejamento ambiental, como gerenciamento de áreas rurais (PIRES, 1995), monitoramento de fragmentos florestais (BARGUIL, 1998 e TOPPA, 1999), análise de áreas de conservação ambiental (ALVARENGA, 1997 e PIRES, 1999), potencial de irrigação (PAVESI,1998), entre outros, podendo ser considerada como técnica dominada, pelo menos na esfera acadêmica, e também no âmbito das administrações públicas, utilizada pelos setores de planejamento ou centros especializados. No entanto, esse recurso ainda não está disponibilizado para os técnicos que trabalham diretamente no licenciamento dos recursos naturais.

Considera-se que a utilização das técnicas de geoprocessamento no licenciamento, uma das abordagens prioritárias neste trabalho, irá acrescenta substancial qualidade quando das avaliações de campo e das decisões nessa esfera, pela incorporação de visão mais ampla que é possibilitada através da utilização desse instrumento aos procedimentos usuais.

\subsubsection{As áreas de Reserva Legal do Município de Descalvado}

O status legal do fragmento é uma informação importante sob o ponto de vista das pressões que ele possa vir a sofrer, no que diz respeito à sua exploração futura. Aqueles já averbados são imunes à corte raso e apresentam possibilidade de utilização muito limitada (manejo sustentado com elevado grau de restrição), podendo, portanto, servir como um ponto referencial da paisagem que deve remanescer. Com relação a eles, deve-se considerar, sobretudo, as pressões negativas do entorno.

Aos remanescentes de vegetação natural não averbados, além das pressões negativas do entorno, deve-se acrescer a possibilidade de serem licenciados à corte raso em até $80 \%$ de sua área total. Conforme já foi dito anteriormente a maior parte das averbações de Reserva Legal está associada a cumprimento de Termo de Ajustamento 
de Conduta firmado com o Promotor de Justiça ou ao requerimento para corte raso de vegetação natural. Nestes casos, a utilização das técnicas de geoprocessamento (GPS e imagem de satélite) deverá servir como baliza para localizar o remanescente na melhor situação possivel, no que diz respeito a suas funções ecológicas, aumentando a possibilidade de restauração dos sistemas e a chance de manutenção de parte da biodiversidade.

Foram levantados junto ao DEPRN - Equipe Técnica de São Carlos, informações sobre os imóveis que apresentavam a Reserva Legal averbada matricula do cartório de registro de imóveis do município de Descalvado, até dezembro de 1999. A relação dos mesmos encontram-se no Anexo 1.

Como já referido, o município apresenta aproximadamente $14.397,61$ ha de sua área em condições naturais ou semi naturais (cerca de 19\%). Verificou-se que 3.294,04 ha ou seja, aproximadamente $23 \%$ da área recoberta com vegetação natural encontra-se protegida como Reserva Legal averbadas, em um total de 49 processos de averbação (Tabela 6 ).

Tabela 6 - Distribuição por tamanho (ha) das Reservas Legais averbadas registradas no municipio de Descalvado até dezembro de 1999. (DEPRN/ETSC)

\begin{tabular}{|c|c|c|c|c|}
\hline Classe (ha) & $\begin{array}{c}\mathrm{N}^{\circ} \text { de Reservas } \\
\text { Legais }\end{array}$ & $\begin{array}{c}\% \text { de Reservas } \\
\text { Legais }\end{array}$ & $\begin{array}{c}\text { Area Protegida } \\
\text { (ha) }\end{array}$ & $\begin{array}{l}\text { \% de Área } \\
\text { Protegida }\end{array}$ \\
\hline 0,1 a 5,0 & 11 & 22,44 & 31,88 & 0,97 \\
\hline 5,1 a 20,00 & 13 & 26,53 & 145,56 & 4,42 \\
\hline 20,1 a 100 & 16 & 32,65 & 814,07 & 24,71 \\
\hline$>100$ & 9 & 18,36 & $2.302,53$ & 69,90 \\
\hline TOTAL & 49 & 100 & $3.294,04$ & 100 \\
\hline
\end{tabular}

Com relação ao tamanho das Reservas Legais, pode-se verificar que cerca de 49 $\%$ das averbações (24) constituem-se de pequenos fragmentos com até 20 ha., protegendo uma extensão de apenas $5,4 \%$ da área total de vegetação natural averbada. 
Entre as Reservas Legais de tamanho médio, com áreas de 20 a 100 ha, com 16 averbações, verificou-se que elas protegem cerca de 814 ha ou quase $25 \%$ cobertura de vegetação natural averbada.

Finalmente, constatou-se que a grande parte da área protegida, aproximadamente 2.302 ha (quase $70 \%$ ), é constituida por grandes Reservas Legais com mais de 100 ha constando de apenas 9 processos de averbação. Assim, pode-se inferir, que decorrentes da regularização de propriedades com mais de 500 ha.

Considerando que foram contabilizadas no municipio de Descalvado apenas 23 propriedades com mais de 500 ha, das quais 9 encontram-se regularizados frente ao Código Florestal, entende-se, então, que as 14 grandes propriedades restantes deveriam ser o objeto maior das atividades do sistema institucional de fiscalização e licenciamento (Policia Florestal, DEPRN e Ministério Público), no sentido de que seus proprietários venham cumprir a determinação legal de averbação de reserva florestal.

Naqueles casos em que a propriedade não possui $20 \%$ de remanescente de vegetação natural conforme determina a Lei, seu proprietário poderia ser autorizado a comprá-la (ou trocá-la por área nua) em outro imóvel que a houvesse em percentuais acima do mínimo legal exigido, no perímetro do município ou mesma bacia hidrográfica. Dessa forma, com aumento da demanda por áreas naturais florestadas e consequentemente do preço, seus proprietários não teriam mais razão para suprimi-las.

$\mathrm{Na}$ Figura 23, pode-se ter uma idéia da abertura de clareiras, autorizadas após averbação da Reserva Legal.

\subsubsection{Procedimentos na Promotoria Pública de Descalvado.}

Na Comarca de Descalvado, no período de 1994 a 1999, foram instaurados na Promotoria de Justiça dezenove procedimentos relacionados a danos ambientais, em sua maioria, por supressão de vegetação natural.

Destes, a maior parte culminou em Termo de Ajustamento de Conduta - TAC, que geralmente consta da obrigação de plantio das áreas autuadas com mudas de árvores nativas da região e averbação de Reserva Legal na matricula dos imóveis autuados, conforme indicações técnicas constantes nos Laudos elaborados por técnicos do DEPRN da Equipe Técnica de São Carlos. Em todos os casos são determinados prazos, bem como multas ou indenizações na hipótese de descumprimento do acordo. 


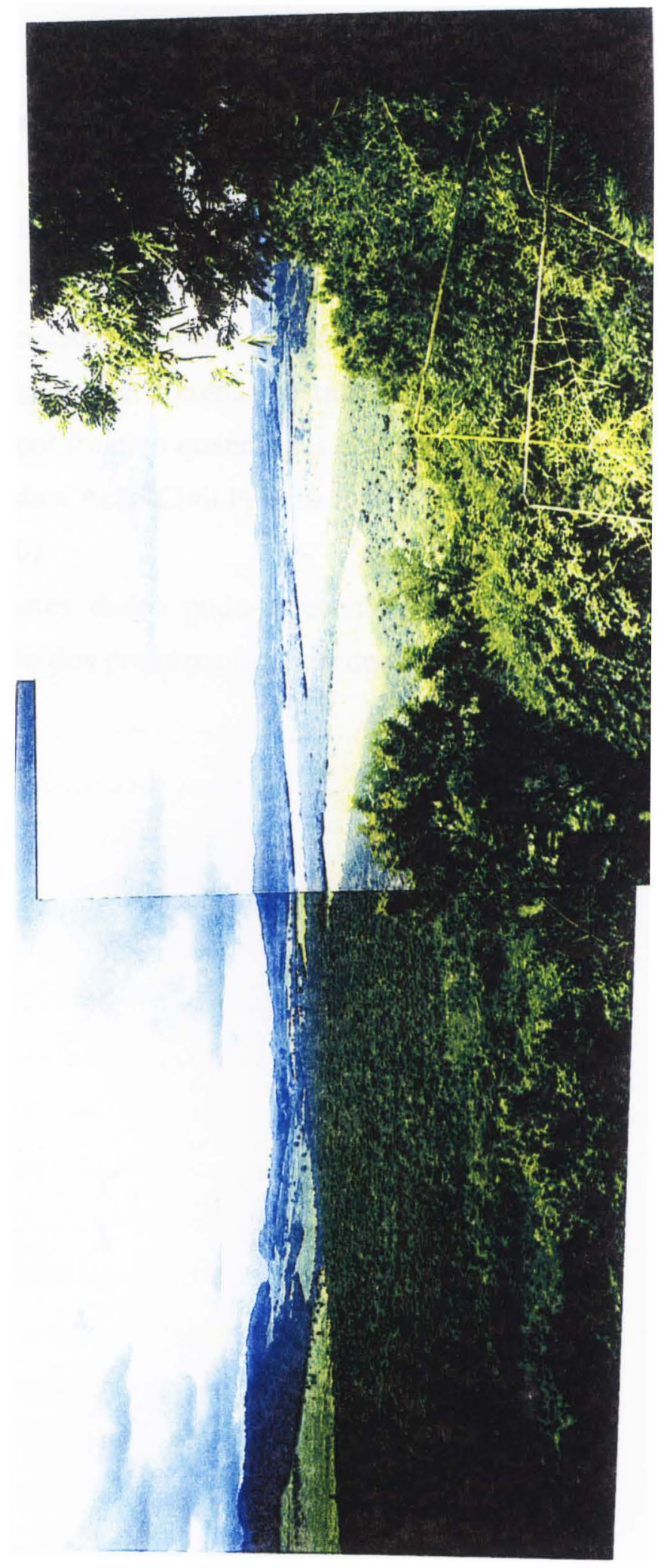

Figura 23 - Corte raso de vegetação nativa após a averbação de Reserva Legal, no município de Descalvado (SP) (SMA/DEPRN/ET São Carlos). 
Os outros dois casos, um deles decorrente de denúncia pública contra a municipalidade local, resultou em Ação Civil Pública, que se encontra em andamento na Justiça local, e visa impedir desmatamento de uma área de cerrado, para implantação de um Distrito Industrial.

O outro, ainda em fase de negociação com a administração municipal, está relacionado à obtenção do licenciamento ambiental da Estação de Tratamento de Esgotos do município, que pretende instalá-la numa área de várzea, onde ocorreu o afloramento do lençol freático quando das obras de implantação. Caso não haja acordo, poderá ser instaurada a Ação Civil Pública (MINISTÉRIO PÚBLICO DO ESTADO DE SÃO PAULO, 2000).

A partir destes dados pode-se concluir a efetiva participação do Ministério Público na reparação dos prejuízos ocasionados ao meio ambiente. 


\section{CONSIDERAÇÕES FINAIS}

Para a aplicação da abordagem ecossistêmica no licenciamento de vegetação natural faz-se necessário, entre outras medidas, incorporar aos instrumentos legais parâmetros voltados à conservação da diversidade biológica.

A ausência destas considerações ecológicas no instrumental legal de uso corrente na prática do licenciamento de vegetação natural permite que estruturas importantes na manutenção do equilibrio ecológico sejam suprimidas.

Como subsídio realização para a proposta do licenciamento de recursos naturais com abordagem ecossistêmica, foi efetuada a caracterização da área de estudo, município de Descalvado (SP), utilizando a integração de dados secundários (geomorfologia, pedologia, hidrografia, etc.) com dados primários, estes obtidos pela análise de imagem de satélite, vistorias em campo, levantamento das reservas legais averbadas nas propriedades privadas e procedimentos relativos a danos ambientais em curso na Promotoria de Justiça.

Constatou-se que a área de estudo apresenta qualidades ambientais peculiares determinantes para estabelecer sua vocação, tais como:

- A ocorrência de vegetação natural considerada como hotspot de biodiversidade, do tipo cerrado em suas diversas fisionomias.

- A vegetação encontra-se dispersa em pequenos fragmentos, em sua maioria, com evidente ameaça aos componentes ambientais desses ecossistemas, como por exemplo a viabilidade da fauna endêmica, com algumas espécies listadas como ameaçadas de extinção.

- A área de estudo se encontra sobre o mais importante aqüifero da América do Sul, apresentando em grande parte de seu território a importante função de recarga desse recurso natural.

- Apresenta, em sua maior parte, elevado índice de susceptibilidade à erosão, com diversos processos erosivos em atividade, que aumentam as possibilidades de degradação dos seus recursos hídricos e diminuição do potencial de recarga dos aqüiferos. 
- Abrange porções das "cuestas" e várzeas que ainda possuem características de seu estado original, com notório potencial de aproveitamento para atividades compatíveis com sua conservação.

Como proposta para assegurar uma base sustentada para o desenvolvimento da região, compatibilizando-o com a efetiva proteção dos recursos naturais, entendese que um dos primeiros passos é a incorporação dos resultados obtidos pela caracterização ambiental, nos processos de licenciamento

Para tanto, estes resultados devem ser traduzidos em um plano de zoneamento ambiental, detalhado em escala compatível com a extensão da área referida, e devidamente institucionalizado, para ser implementado pelos poderes públicos.

Assim, as licenças emitidas deverão respeitar a capacidade de suporte ambiental identificada, conforme preconizado pelo conceito de desenvolvimento sustentável.

Este instrumento deve possuir caráter legal obrigatório e interferir decisivamente nas emissões de licenças para corte de vegetação natural ou apropriação de recursos naturais que envolvam supressão de habitats, permitindo o controle social através da atuação do Ministério Público.

Dessa forma ficariam salvaguardadas as duas principais funções ambientais identificadas no perimetro do município de Descalvado: a função de recarga do aqüífero Botucatu e proteção da biota ameaçada.

Paralelamente, deveria ser estabelecida e implementada na esfera da administração municipal, uma política pública para o desenvolvimento econômico de atividades compativeis com os atributos ambientais do município.

No caso do municipio de Descalvado, foi verificado que as áreas marginais do rio do Pântano, de sua cabeceira, ao sul, até à sua desembocadura no Rio MogiGuaçu, constituem importante recurso para a manutenção da diversidade biológica, onde deve ser estabelecido o caráter de restrição máxima para manutenção da vida silvestre.

A realização de tal manejo permitiria a interligação da biota do relevo ingreme do sul, passando pelas terras onduladas da região central, com parte da planicie de inundação da porção média do Rio Mogi-Guaçu, situada ao norte. 
As marginais ao Rio Mogi-Guaçu serviriam como interligação dessas áreas às três unidades de conservação situadas nos municípios de Porto Ferreira, Santa Rita do Passa Quatro e Luiz Antonio. Dessa forma, ficariam conectados habitats bastante variados, condicionados pela diversidade geomorfológica no âmbito da paisagem. Entretanto, devem ser realizados estudos para determinação da largura destes "corredores", levantamento do uso e ocupação atual desse solo com vistas ao desenvolvimento do plano de manejo desses locais, bem como das áreas lindeiras, visando a estratégia de conservação da biodiversidade numa abordagem inter-situ.

Essas áreas já se encontram inseridas no perímetro da APA municipal, ainda não implementada pela ausência de Zoneamento Ecológico-Econômico.

Ainda no âmbito municipal, devem ser realizados estudos para determinação de outras áreas com função ambiental relevante, para criação de Unidades de Conservação de proteção integral (UC de uso indireto), como estratégia de conservação da biodiversidade in situ.

Os estudos preconizados devem ter abrangência interdisciplinar, contemplando, inclusive, profissionais das áreas das ciências sociais, para que sejam considerados os aspectos culturais, facilitando a implementação.

Com base no perfil obtido em relação as áreas de Reserva Legal averbadas no municipio de Descalvado, considera-se que devem ser concentrados esforços do sistema institucional, afim de que todas as grandes propriedades ( $>500 \mathrm{ha}$ ) sejam regularizadas frente ao Código Florestal, averbando as Reservas Legais.

Além disso, como medidas de caráter geral, entende-se como fundamental o estabelecimento de instrumentos econômicos eficazes, através de subsídios ou valoração econômica, para áreas com relevante função ambiental localizadas em propriedades particulares, como estímulo à sua manutenção e de forma a não onerar estes proprietários.

Estudos para a utilização sustentável das áreas florestais e outras formas de vegetação natural devem ser estimulados na esfera acadêmica, de forma a subsidiar a implantação de projetos economicamente viáveis nesses ecossistemas. Entre estes, destacam-se, especialmente, àqueles voltados ao ecoturismo e turismo rural, educação ambiental e ao manejo sustentado dos recursos florestais, tais como, exploração de ervas medicinais, frutas e flores, apicultura, entre outros. 


\section{CONCLUSÕES}

A ausência da concepção do desenvolvimento sustentável nas decisões sobre políticas agrícolas, urbanas e industriais vem fazendo com que a pressão sobre as áreas florestadas (habitats) aumentem dia a dia e suas conseqüências já atinjam o próprio sistema produtivo, através da desperinização de córregos, desertificação de áreas, enchentes, e até alterações climáticas.

Embora os objetivos e premissas da política ambiental no Brasil, aí inserida a politica florestal, estejam claramente definidos, incorporando os princípios do caráter de bem comum do meio ambiente, do conceito de desenvolvimento com sustentabilidade e da conservação da biodiversidade, explicitados, entre outros, na própria Constituição Federal de 1988 e nos diversos acordos internacionais, como a Agenda 21 e a Convenção sobre a Diversidade Biológica, faz-se necessária a operacionalização dos seus instrumentos, para que os mesmos sejam alcançados.

A incorporação destes conceitos na utilização de recursos naturais, reconhecidos como imprescindíveis para a estabilidade do planeta e perpetuidade das espécies, deve ser consolidada pela utilização eficiente de instrumentos de gestão na sua implementação.

Assim, o licenciamento ambiental pode ser considerado o braço executivo da implementação das políticas na área, e o seu desempenho depende da correta aplicação das leis, regulamentações, normas e diretrizes elaboradas para o setor.

A legislação é a ferramenta de ação mais efetiva para implementação da política e gestão ambiental, uma vez que disciplina juridicamente a matéria e a obrigação de fazer ou não fazer. Quando aplicada no decorrer dos processos de licenciamento, tem caráter de medida preventiva, na proteção das florestas e dos recursos naturais. Nas atividades de fiscalização, é aplicada como medida corretiva, com prescrição de penas e/ou multas aos infratores.

Nos últimos anos, o Ministério Público, de uma forma geral, através de suas Curadorias do Meio Ambiente, vem atuando com muita competência na fiscalização do cumprimento dos ditames legais em defesa do meio ambiente.

Entretanto, apesar do claro posicionamento das várias esferas de governo na conservação e uso sustentável das áreas com relevante interesse ambiental, ainda são 
autorizadas a corte raso formações florestais que tecnicamente deveriam ser mantidas. Nesse sentido, entende-se que tal fato decorre da falta de implementação de outros instrumentos de gestão previstos em lei, que agregam ao licenciamento a visão sistêmica e das funções ambientais, que não são considerados quando da análise pontual. São considerados indispensáveis na prática do licenciamento com abordagem ecossistêmica: o Sistema de Unidades de Conservação, o Plano Diretor, o Zoneamento Ambiental, incentivos econômicos para manutenção de áreas florestadas, entre outros.

Da análise do instrumental legal utilizado na prática corrente do licenciamento de vegetação natural, conclui-se que:

As formações de mata atlântica a partir de estágio médio de desenvolvimento e matas de galeria encontram-se bem protegidas pela legislação.

$>$ As florestas e demais formas de vegetação natural em várzeas não apresentam proteção legal suficiente sendo passiveis de utilização em até $80 \%$, desde que cumpridas algumas exigências técnicas.

O cerrado, uma das fisionomias mais ameaçadas do Brasil e do Estado de São Paulo, e o principal bioma na área de estudo, município de Descalvado, está desaparecendo, apesar do reconhecimento cientifico do seu valor em termos de manutenção de diversidade biológica. Não existe legislação específica para sua proteção. No Código Florestal, esse bioma é referido como forma de vegetação que é passível de autorização à corte raso em $80 \%$ da área.

Atualmente a forma mais utilizada pelo sistema institucional para de preservação dos fragmentos florestais é a averbação de Reservas Legais. Entretanto, na maior parte das vezes, a instituição das Reservas Legais está associada à autorização de desmatamento e restrita somente àquelas propriedades que ainda apresentam remanescentes em percentuais superiores aos $20 \%$. Dessa forma, embora seja um bom instrumento para coibir a degradação total dos habitats florestais, da sua prática acaba ocorrendo a intensa fragmentação dos remanescentes, com a criação de muitas "ilhas" de vegetação natural.

Entretanto, se a averbação de Reserva Legal for exigida de todos os proprietários, independentemente de terem ou não fragmentos de vegetação natural em suas propriedades, aliada à possibilidade de compra ou locação de áreas florestais 
de outros proprietários que a tenham em percentual excedente a $20 \%$, conclui-se que os requerimentos de desmatamento no Estado de São Paulo irão diminuir substancialmente, se não terminar, como conseqüência da valorização econômica destas áreas, pelo aumento da demanda, uma vez que a cobertura florestal no Estado é de aproximadamente $7,5 \%$ de sua área total.

Do estudo de caso, no município de Descalvado, com base na análise da distribuição da cobertura de vegetação natural, conclui-se que a grande maioria dos fragmentos remanescentes são muito pequenos e pequenos (com até $20 \mathrm{ha}$ ), cobrindo uma extensão de apenas $17,5 \%$ do total da área vegetada. Os fragmentos de tamanho médio e grandes, com mais de 20 ha, embora ocorram em menor número (cerca de $16 \%$ dos registros), representam grande parte da cobertura de vegetação natural na área de estudo, ou quase $83 \%$. Esse quadro indica que a área com cobertura de vegetação natural na área de estudo encontra-se altamente fragmentada, e sob forte pressão negativa pela atividade antrópica desenvolvida nos seus entornos.

As formações de vegetação nativa identificadas em campo foram: cerrado, em todas as suas fisionomias; floresta estacional semi-decidual, matas de galeria e campos de várzea.

As áreas referidas no presente trabalho como fragmentos de vegetação natural são consideradas remanescentes da cobertura original da área de estudo, que era composta por matas (florestas estacionais semi-deciduais), cerradões, cerrado senso estrito, campos cerrados, mata ripária ou ciliar e outras formações vegetais conhecidas por banhados, brejos ou várzeas. Considerando que estes fragmentos remanesceram das diversas formas de perturbação, sejam elas naturais ou antrópicas, observa-se, no município de Descalvado, uma regressão de $80 \%$ de áreas naturais convertidas para outros usos, ou mais, se forem considerados como pouco viáveis para conservação da diversidade biológica os fragmentos muito pequenos.

A metodologia proposta neste trabalho para as atividades de licenciamento, que é a utilização das técnicas de geoprocessamento associada ao trabalho de campo, possibilitou a visão ecossistêmica preconizada, auxiliando sobremaneira na visualização dos fragmentos vistoriados individualmente como elementos da paisagem. Sua utilização certamente irá acrescentar substancial qualidade na tomada de decisão nos processos de licenciamento, pela incorporação da visão mais ampla 
do que as àquela obtida pela simples análise pontual.

Considera-se que, na atividade do licenciamento de áreas florestais voltada para a conservação da biodiversidade, a conjunção dessas duas abordagens constituise a forma ideal de diagnóstico. Por um lado, a avaliação de campo fornece uma percepção das peculiaridades da área, que são impossiveis de serem percebidas pelas imagens; em contrapartida, a imagem fornece uma visão macro do quadro ambiental, como a dispersão, fragmentação e conectividade entre as áreas de vegetação natural. Dessa forma, além de possibilitar a determinação da função ecológica do fragmento, deverá servir como baliza para locação das Reservas Legais, no sentido de que haja maior possibilidade de restauração dos sistemas ecológicos e manutenção da viabilidade de pelo menos parte da biodiversidade, mesmo quando das autorizações de supressão de vegetação natural.

A consideração dos aspectos fisicos, tais como, acidentes topográficos de paisagem (serras e outros), bacia hidrográfica (drenagem), entre outros, são fatores imprescindiveis de consideração quando da tomada de decisão relativa à apropriação de um recurso natural. A caracterização do solo e as análises de susceptibilidade à erosão constituem-se importantes ferramentas para ações de planejamento regional e são informações das mais relevantes na caracterização ambiental e, portanto, deveriam ser consideradas efetivamente na prática do licenciamento florestal.

Analisando a elevada diversidade geomorfológica encontrada na área de estudo, verifica-se que a mesma condiciona uma grande diversidade de habitats que, consequentemente, está relacionada a uma elevada biodiversidade na área de estudo. Conforme abordagem adotada no presente trabalho a análise ambiental voltada ao planejamento focaliza a diversidade de ecossistemas ou habitats, uma vez que a diversidade biológica ao nivel de espécies e genes é extremamente dificil de ser avaliada. 


\section{REFERÊNCIAS BIBLIOGRÁFICAS}

ALMEIDA, L. T. Política ambiental - uma análise econômica. Edit. UNESP/ Papirus, 1998. 192p.

ALVAREnGa, S.R. A análise de Áreas de Proteção Ambiental como instrumento da Política Nacional do Meio Ambiente: o caso da APA Corumbatai - SP. Dissertação (Mestrado), USP/Escola de Engenharia de São Carlos, São Carlos, 1997. 216p.

BARGUIL, S.R. Geoprocessamento aplicado ao monitoramento de cerrado: um estudo de caso na porção noroeste da APA Corumbataí (SP). Dissertação (Mestrado), USP/Escola de Engenharia de São Carlos, São Carlos, 1998, $151 \mathrm{p}$.

BRANDÃO, G. L. Desafio Florestal Brasileiro. Silvicultura, Ano XVIII, n.73, p. 23-29, 1997.

BRASIL. Constituição da República Federativa do Brasil. S. Paulo, Editora Saraiva, 22 Ed., 1999. 273p.

BRASIL. Decreto Federal $N^{\circ} 2$, de 08/02/1894,que aprova o texto da Convenção sobre Diversidade Biológica. DOU, Seção 2. 1994.

BRASIL. Ministério do Meio Ambiente, dos Recursos Hídricos e da Amazônia Legal. IBAMA. Lei da Natureza. Lei de Crimes Ambientais. IBAMA/MMA, Brasília, 1998, 62p.

BRITO, M. C. W. ; VIANNA, L. P.; AZEVEDO, C. M. A.; FONSECA, F. P; CARVALHO, D. M. D. Unidades de Conservação. PROBIO/SP - Secretaria do Estado do Meio Ambiente/SP. São Paulo, SP. 1999. [Endereço eletrônico: www.probio.sp@cetesb.sp.gov.br]

CANADA. L'état des Forêts au Canada (1994) - Une question d'équilibre. Ressources naturelles. Canada, Service Canadien des forêts, 1994. $111 \mathrm{p}$.

CANADA. L'état des Forêts au Canada 1995-1996. Maintien des forêts d'ici et à l'étranger. Ressources naturelles. Canada, Service Canadien des forêts, 1995-1996. $112 \mathrm{p}$. 
CANADA. L'état des Forêts au Canada 1996-1997 - Les leçons du passé. Canada, Service Canadien des forêts, 1996-1997. 127 p.

CASTELUCCI, S. Um estudo etnobotânico sobre plantas medicinais levantadas junto aos moradores da Estação Ecológica do Jataí. São Carlos, 1995. Monografia de Graduação. CCBS, UFSCar. 94p.

CONSERVATION INTERNATIONAL. Hotspots e Wilderness Áreas. [Endereço eletrônico: http://wu'w.conservation.org.br/hotspotsíindex.html - 26/09/2000].

COUTINHO, L.M. O conceito de cerrado. Revista Bras. Botan. 1, 17-23, 1978.

DALMOLIN, P.C. Composição e história natural da comunidade de serpentes da Estação Ecológica do Jataí e município de Luiz Antonio, SP. S. Carlos, 1999. Dissertação de Mestrado em Ecologia. PPG-ERN, CCBS, UFSCar. $99 \mathrm{p}$.

DIAS, B.F.S. 2000. A implementaçāo da Convenção sobre a Diversidade Biológica no Brasil: Desafios e Oportunidades. [Endereço eletrônico: http://www.bdt.org. hr/publicacoes/padct/bioicapl/index.html - 06/09/2000].

DIAS, B.F.S. Alternativas de Desenvolvimento do Cerrado: manejo e conservação dos recursos naturais renováveis. Brasília, 1992, FUNATURA. 97p.

DIAS-FILHO, M. Avifauna da Estação Ecológica do Jatai - Luiz Antonio, SP. Em: Workshop do Projeto Jatai, 1. S. Carlos, 1994. Anais... S. Carlos: PPG-ERN, UFSCar. 3p.

DIEGUES, A.C.S. O mito moderno da natureza intocada. S. Paulo, Edit. NUPAUB. $163 \mathrm{p}$.

DUARTE, OSNY PEREIRA. Direito Florestal Brasileiro. Rio de Janeiro, Borsói, data do prefácio 1950, citado em SILVA, 1998.

EITEN, G.A. Vegetação do Estado de São Paulo. Bol. Inst. Bot. 7, 174p. 1970.

FREITAS, V. P. e FREITAS, G. P. Crimes contra a natureza. 2 ed. S. Paulo, Editora Revista dos Tribunais Ltda., 1991, 242p.

KRONKA, F.J.N. Áreas de Dominio do Cerrado no Estado de São Paulo. S. Paulo, Secretaria do Meio Ambiente, 1998. 84p.

MACHADO, P. A. L. Direito Ambiental Brasileiro. $2^{a}$ ed. S. Paulo, Editora Revista dos Tribunais, 1989, 478p. 
MACHADO, P. A. L. Direito Ambiental Brasileiro. 6a ed. S. Paulo, Editora Malheiros, 1996.

MANTOVANI, W. Vegetação - Estágios Sucessionais. Em: Governo do Estado de São Paulo, Secretaria do Meio Ambiente, Coordenadoria de Licenciamento Ambiental e Proteção de Recursos Naturais, Departamento Estadual de Proteção de Recursos Naturais. Curso de Reciclagem Técnica - DEPRN/PFM - Apostila Técnica, 1997, Tema: Tipificação de Vegetação e Legislação Florestal. p. 138-144.

MINISTÉRIO DA FAZENDA. ITR - Imposto sobre a Propriedade Territorial Rural. Declaração do ITR - Manual para preenchimento. 1997.

MINISTÉrIO PÚBliCO DE ESTADO DE SÃo PAUlO. Promotoria Pública de Descalvado. Procedimentos relativos a danos ambientais. Consulta aos arquivos. Descalvado, abril de 2000.

MOORE, P. Capacidade de Regeneração das Florestas. Silvicultura, Ano XVII, n. 73 , p. $30-34,1997$.

MORAES, A. C. R. Meio Ambiente e Ciências Humanas. S. Paulo, Edit. Hucitec. 1994.

MORAES, L. C. S. Código Florestal Comentado. S. Paulo, Editora Atlas S.A., 1999. 260p.

ODUM, E.P. Ecologia. Editora Guanabara, Rio de Janeiro, 1988. 434p.

ODUM, E.P. Ecology and our endangered life-support systems. $2^{\text {nd }}$. Ed. 1993.

OLIVEIRA, H. H. Proposta para criação e caracterização da Área de Proteção Ambiental de Descalvado - S.P. Dissertação (Mestrado), ICB/USP, 1997. $140 \mathrm{p}$.

OLIVEIRA, J.B.; PRADO, N. e ALMEIDA, C.F. Levantamento pedológico semidetalhado do Estado de São Paulo. Convênio EMBRAPA - Secretaria de Agricultura e Abastecimento do Estado de S. Paulo. 1992.

PAVESI, A. Ponderação dos fatores ambientais na localização de áreas irrigáveis e na cobrança do uso da água para irrigação. Dissertação (Mestrado), EESC/USP, 1998.

PÉLLICO NETTO, S. e BRENA, D. A. Inventário Florestal. Universidade Federal do Paraná, Universidade Federal de Santa Maria. Curitiba, 1993. 273p. 
PINTO, M.T.C. Dinâmica de nutrientes na mata galeria da lagoa do Diogo (Estação Ecológica do Jataí, Luiz Antonio, SP). S. Carlos, 1992. Tese de Doutorado em Ecologia. S. Carlos, |PPG-ERN, CCBS, UFSCar. 364p.

PIRES, A.M.Z.C.R. Plano de Manejo Conceitual para a Conservação da Biodiversidade. Estudo de Caso: Estação Ecológica do Jataí (Luiz Antonio - SP). UFSCAR/ Centro de Ciências Biológicas e da Saúde. Tese de Doutorado, São Carlos. 1999, 192p.

PIRES, J.S e PIRES, A.M.Z.C.R. Considerações sobre a estratégia de conservação ïnter situ. (no prelo).

PIRES, J.S. Análise Ambiental voltada ao planejamento e gerenciamento do ambiente rural: abordagem metodológica aplicada ao município de Luiz Antonio - SP. UFSCAR/ Centro de Ciências Biológicas e da Saúde. Tese de Doutorado, São Carlos. 1995, 193p.

PIRES, J.R.; SANTOS, J.E.; PIRES, M.Z.C.R.; MANTOVANI, J.E.; PAESI, A. Estratégia "inter-situ" de conservação: elaboração de cenários regionais para conservação da biodiversidade. Anais do V Simpósio de Ecossistemas Brasileiros: Conservação. UFES, Vitória, ES, 10 a 15/10/2000.

PNF (PROGRAMA NACIONAL DE FLORESTAS). BRASIL. Ministério do Meio

Ambiente. Brasilia, 2000 (Endereço eletrônico: http://www.mma.gov.br/pot/ sbf/pnf/acoesproj.html)- 26/09/2000

PRADO, H. Os solos do Estado de São Paulo - mapas pedológicos. Manah/Embrapa, 1997, 205 p.

PRADO, H. Solos Tropicais - potencialidades, limitações, manejo e capacidade de uso. $2^{\circ}$ ed. Jaboticabal, FUNEP/UNESP, 1998. $231 \mathrm{p}$.

PREFEITURA MUNICIPAL DE DESCALVADO. Projeto Corredores Ecológicos na Microbacia do Rio do Pântano da APA de Descalvado. Proposta de projeto apresentada ao FNMA. Descalvado, 1999. $16 \mathrm{p}$.

RANIERI, V. E. L. Determinação das Potencialidades e Restrições do Meio Físico como Subsídio para o Zoneamento Ambiental - Estudo de Caso do Município de Descalvado (SP). Dissertação (Mestrado), EESC/USP, 2000. $71 \mathrm{p}$. 
SAA (Secretaria de Agricultura e Abastecimento do Estado de S. Paulo). Projeto LUPA - 1995/1996. [Endereço eletrônico: www2.cati.sp.gov.br/lupat/ descalvado - 06/10/99].

SACHS, I. Ecodesenvolvimento: crescer sem destruir. São Paulo, Editora Vértice, 1986.

SACHS, I. Estratégias de transição para o século XXI. Em: Bursztyn, M. (org.), Para pensar o desenvolvimento sustentável. $2^{\mathrm{a}}$ ed. S. Paulo, Edit. Brasiliense, 1994.

SANTOS, M.C.S.R. Manual de fundamentos cartográficos e diretrizes gerais para elaboração de mapas geológicos, geomorfológicos e geotécnicos.

SÃo PAUlo (Governo do Estado de São Paulo, Secretaria de Estado do Meio Ambiente, Secretaria da Agricultura e Abastecimento, Secretaria de Economia e Planejameno). Macrozoneamento das Bacias dos Rios Mogi Guaçu, Pardo e Médio Grande. Questões Sócio-Ambientais Regionais. São Paulo, 1995. 168 p.

SÃo PAULO (Governo do Estado de São Paulo, Secretaria de Estado do Meio Ambiente). Decreto 750 - Mata Atlântica - Regulamentação para o Estado de São Paulo. São Paulo, SMA. Série Documentos Ambientais. 1997. 49p.

SÃo PAULO (Governo do Estado de São Paulo, Secretaria de Estado do Meio Ambiente). Fauna Ameaçada no Estado de São Paulo. Série PROBIO/SP, São Paulo, 1998. 60 p.

SÃo PAULO (Governo do Estado de São Paulo, Secretaria de Estado do Meio Ambiente). CERRADO: Bases para conservação e uso sustentável das áreas de cerrado do Estado de São Paulo. Série PROBIO/SP, São Paulo, junho, 1997. $184 \mathrm{p}$.

SÃo PAULO (Governo do Estado de São Paulo/Secretaria de Estado do Meio Ambiente). Região Sudeste 92: Perfil ambiental e estratégias. Projeto Eco 92. S. Paulo, Secretaria do Meio Ambiente, 1992. 108 p.

SÃo PAULO (Governo do Estado de São Paulo/Secretaria de Estado do Meio Ambiente). Diretrizes para a Política Ambiental do Estado de São Paulo. Série Documentos. Secretaria do Meio Ambiente, 1993. 35 p.

SÃo PAULO. Constituição do Estado de São Paulo. IMESP, 1989. 48p. 
SILVA, J.A. Direito Ambiental Constitucional. Malheiros Editores, $2^{\circ}$ ed. revista, $3^{\circ}$ tiragem, 1998, 243p.

SOUZA, M.P. Instrumentos de Gestão Ambiental: Fundamentos e Prática. Ed. Riani Costa, 2000. 108p.

SOUZA, M.P. Metodologia de cobrança sobre os usos da água e sua aplicação como instrumento de gestão. Tese de Doutorado. Faculdade de Saúde Pública da USP, 1993.

T. ALVES ENGENHARIA. Estudo de Impacto Ambiental - Mineração Descalvado. T. Alves Engenharia S/C Ltda. São Paulo, março/1990.

TALAMONI, S.A. Ecologia de uma comunidade de pequenos mamíferos da Estação Ecológica de Jataí, município de Luiz Antonio, SP. São Carlos, SP.1996. Tese de Doutorado em Ecologia. PPG-ERN, CCBS, UFSCar.

TALAMONI, S.A.; MOTTA-JUNIOR, J.C. e DIAS-FILHO, M.M. Mamiferos não voadores das Estações Ecológica e Experimental de Jataí - Luiz Antonio, SP: estudos preliminares. Workshop do Projeto Jatai, 1. Anais... São Carlos, PPG/ERN/UFSCar, 1994.

TOLBA, M.K Development without destruction: evolving environment perception. Tycooly Intern Publ. Ltd., Dublin, Ireland. 1982.

TOLEDO-FILHO, D.V. Composição florística, estrutura fitossociológica da vegetação de cerrado no município de Luiz Antonio (SP). Campinas, 1984. Dissertação de Mestrado em Biologia Vegetal. Instituto de Biologia/ UNICAMP. 173p.

TOPPA, R.H. Análise Ambiental de Um Fragmento de Cerradão Como Subsídio para Conservação da Biodiversidade. Dissertação (Mestrado em Ecologia), UFSCAR/CCBS/PPG-ERN, São Carlos, SP, 1999. 103p.

TURNER, M. G. e GARDNER, R. H., Ed. Quantitative Methods in Landscape Ecology. The analysis and Interpretation of Landscape Heterogeneity. 1991.

UFSCar (Universidade Federal de S. Carlos)/LAPA (Laboratório de Análise e Planejamento Ambiental). Acervo Cartográfico Digital, 2000.

VENTURA, J.V. e RAMBELLI, A.M. Legislação Federal sobre o Meio Ambiente - Legislação Federal anotada. $2^{a}$ ed. Taubaté, Editora Vana, 1996, 1148 p. 
WWF e PRO-CER. De grão em grão o cerrado perde espaço (Cerrado impactos de processo de ocupação). Endereço eletrônico: http://www.bdt. org.br/cerrado/dominio - 26/09/2000.

\section{BIBLIOGRAFIA COMPLEMENTAR}

AB'SABER, A.N. Contribuição à geomorfologia da área dos cerrados. In: Simpósio sobre Cerrado, São Paulo, EDUSP, 117-124, 1962 (citado por KRONKA, 1998).

BURNETT, M. R. et al. The Influence of Geomorphological Heterogenity on Biodiversity. I. A patch-scale perspective. Conservation Biology, 12 (2) :263-270, 1998 (citado por PIRES, 2000).

RIZZINI, C.T. Tratado de fitogeografia do Brasil: aspectos sociológicos e florísticos. São Paulo, Ed. Humanismo, Ciência e Tecnologia/EDUSP,1979. V.2. (citado por Oliveira, 1995). 


\section{ANEXO 1}

Relação das Reservas Legais Averbadas no Município de Descalvado, SP (SMA/DEPRN/ ET São Carlos, 2000)

\begin{tabular}{|c|c|c|c|c|}
\hline Interessado & Nome do imóvel & Proc. SMA & $\begin{array}{l}\text { Área do } \\
\text { Imóvel } \\
\text { (há) }\end{array}$ & $\begin{array}{c}\text { Área da } \\
\text { Reserva Legal } \\
\text { (ha) }\end{array}$ \\
\hline 1. Alcides Raimundo & Sitio Santa Rosa & $82.181 / 94$ & & 4,566 \\
\hline 2. Antônio Hypólito & Sítio Ipê & $82.103 / 92$ & & 2.41 \\
\hline $\begin{array}{l}\text { 3. Antonio C. F. } \\
\text { Camargo }\end{array}$ & Faz. Bandeira & 194 & & 65,24 \\
\hline $\begin{array}{ll}\text { 4. Antônio Carmo } \\
\text { Drago }\end{array}$ & Faz. Monte Alverne & $82.339 / 94$ & & 384,43 \\
\hline 5. Antônio Paggiaro & $\begin{array}{l}\text { Faz. Pau d'Alho da } \\
\text { Grama }\end{array}$ & 191 & 1162,2 & 235,07 \\
\hline 6. Antônio Paggiaro & $\begin{array}{l}\text { Faz. Pau d'Alho da } \\
\text { Grama }\end{array}$ & $82.077 / 91$ & & 38,29 \\
\hline 7. Armando Mauro & Sitio São José & $82.233 / 95$ & & 36,30 \\
\hline 8. Celeste Gargantini & $\begin{array}{l}\text { Sítio Sto. Ant. de } \\
\text { Pádua } \\
\end{array}$ & $82.069 / 92$ & & 14,45 \\
\hline $\begin{array}{l}\text { 9. Donizetti Sebastião } \\
\text { Thomaz }\end{array}$ & Sitio Santa Rita & $82.013 / 93$ & & 7,44 \\
\hline $\begin{array}{l}\text { 10. Faz. Reun. Sérgio } \\
\text { Bardella }\end{array}$ & Faz. São Roberto & $82.013 / 96$ & & 219,84 \\
\hline $\begin{array}{l}\text { 11. Fazenda Jaguarão } \\
\text { Ltda. }\end{array}$ & Faz. Jaguarão & 191 & & 427,74 \\
\hline 12. Francisco Dituri & & 191 & & 12.76 \\
\hline 13. Fritz Herman Wild & Estância Colibri & & 25.97 & 11.25 \\
\hline $\begin{array}{l}\text { 14. Humberto de } \\
\text { Campos }\end{array}$ & Estância Veridiana & $82.081 / 93$ & & 23,18 \\
\hline 15. Idalino Cantarelli & Chac. Gilda & 191 & & 1.35 \\
\hline 16. Imob. Descalvado & $\begin{array}{l}\text { Sít. N. Senhora } \\
\text { Aparecida gl. } 8\end{array}$ & $82.092 / 90$ & & 5,20 \\
\hline 17. Irmãos Cury & Faz. São Pedro & $82.093 / 92$ & & 83.80 \\
\hline 18. João A. Paggiaro & Faz. Grama & $82.077 / 91$ & & 5.62 \\
\hline 19. João C. Couvre & & $82.236 / 93$ & & 5.625 \\
\hline 20. João G.Traldi & $\begin{array}{c}\text { Faz. Sto. Ant. da Boa } \\
\text { Vista }\end{array}$ & $82.194 / 97$ & & 22,47 \\
\hline $\begin{array}{l}\text { 21. João Laureano } \\
\text { Pavan } \\
\end{array}$ & Estancia Sta. Lúcia & $82.031 / 93$ & & 3,49 \\
\hline 22. Jorge Rosini Filho & Faz. Graciosa & $82.256 / 93$ & & 116.43 \\
\hline 23. José Biazolli & Estância Chamonix & $82.128 / 97$ & & 15.63 \\
\hline 24. José C. Adorno & Faz. São Francisco & $82.111 / 93$ & & 22.57 \\
\hline $\begin{array}{l}\text { 25. Luciano } \\
\text { Lewandovski }\end{array}$ & Faz. Itaúna & & 923.05 & 121,05 \\
\hline 26. Luiz A. Muller & Faz. Sta. Eulália & $82.113 / 91$ & & 65.784 \\
\hline 27. Luiz A. Muller & Faz. Sta. Eulália & $82.206 / 95$ & & $\begin{array}{l}10.73 \\
3.60 \\
\end{array}$ \\
\hline 28. Luiz A. Muller & Faz. Sta. Eulália & 191 & & 134.55 \\
\hline 29. Luiz Ant. Jordão & Chac. Vista Alegre & & 4.79 & 1.02 \\
\hline $\begin{array}{l}\text { 30. Luiz. Dias } \\
\text { Alvarenga }\end{array}$ & Faz. Tamandaré & $82.197 / 92$ & & 75.72 \\
\hline $\begin{array}{l}\text { 31. Luiz Femando } \\
\text { Gentil Gabrielli }\end{array}$ & Faz. Jaguarandi & $82.034 / 93$ & & 23.83 \\
\hline
\end{tabular}




\begin{tabular}{|c|c|c|c|c|}
\hline Interessado & Nome do imóvel & Proc. SMA & $\begin{array}{l}\text { Área do } \\
\text { Imóvel } \\
\text { (há). }\end{array}$ & $\begin{array}{c}\text { Área da } \\
\text { Reservà'Legàl' } \\
\text { (ha) }\end{array}$ \\
\hline $\begin{array}{l}\text { 32. Manoel A. Dias } \\
\text { Anchão }\end{array}$ & Faz. Mercedes & $82.154 / 93$ & $=\cdots$ & 66,00 \\
\hline 33. Manoel S. Moreira & Granja Mirassol & 191 & & 2,23 \\
\hline 34. Mário Biazolli & $\begin{array}{l}\text { Sít. N. Senhora } \\
\text { Aparecida }\end{array}$ & $82.092 / 90$ & & 17,61 \\
\hline 35. Melhem Kalil & Est. Sta. Lúcia & 191 & & 4.84 \\
\hline 36. Mineração Jundú & $\begin{array}{l}\text { FazFartura/Faz.SãoJoa } \\
\text { quim/São Benedito }\end{array}$ & $82.106 / 96$ & & 93,22 \\
\hline 37. Mineração Jundú & Sítio Estiva & $82.086 / 92$ & & 12.54 \\
\hline $\begin{array}{l}\text { 38. Mineração Jundú } \\
\text { Ltda. }\end{array}$ & FazIbicoara/Guanabara & 191 & & 40,35 \\
\hline 39. Pedro Castiglioni & $\begin{array}{l}\text { Sít. N. Senhora } \\
\text { Aparecida }\end{array}$ & $82.092 / 90$ & & 4,14 \\
\hline 40. Pedro Marcato & Sem nome & $82.230 / 95$ & & 2.97 \\
\hline $\begin{array}{l}\text { 41. Plinio Paulo } \\
\text { Paludetti }\end{array}$ & Faz. Bom Jesus & $82.084 / 92$ & & 48.28 \\
\hline 42. Sebastião Franzinet & $\begin{array}{l}\text { Faz. Três Barras/Faz. } \\
\text { Sta. Barbara }\end{array}$ & $82.081 / 94$ & & 62.98 \\
\hline $\begin{array}{l}\text { 43. Sonia Caucabene } \\
\text { Sichirolli }\end{array}$ & & $82.114 / 91$ & & 46,06 \\
\hline $\begin{array}{l}\text { 44. Umberto Pecenin } \\
\text { (Imob.Descalvado) }\end{array}$ & Chac. Primavera & $82.092 / 90$ & & 1,26 \\
\hline 45. Vitorino Pozzi Jr. & Rec. Suello Promesso & $82.004 / 92$ & & 19.20 \\
\hline 46. Rosa Pozzi & $\begin{array}{c}\text { Santa Maria São } \\
\text { Francisco } \\
\end{array}$ & $56.113 / 84$ & 2130,46 & 426,09 \\
\hline $\begin{array}{l}\text { 47. Mineração } \\
\text { Descalvado }\end{array}$ & $\begin{array}{c}\text { Santa Maria São } \\
\text { Francisco }\end{array}$ & & & \\
\hline 48. Caninha 51 & $\begin{array}{c}\text { Santa Maria São } \\
\text { Francisco }\end{array}$ & $82.014 / 91$ & 934.12 & 237,33 \\
\hline 49. Prefeitura & $\begin{array}{c}\text { Santa Maria São } \\
\text { Francisco }\end{array}$ & & 36,00 & 7,50 \\
\hline TOTAL(ha.) & & & & 3294,04 \\
\hline
\end{tabular}

